\title{
Equality Denied: Tech and African Americans
}

\section{William Lazonick, ${ }^{*}$ Philip Moss ${ }^{* *}$ and Joshua Weitz ${ }^{* * *}$}

\author{
Working Paper No. 177
}

\author{
February $18^{\text {th }}, 2022$
}

\begin{abstract}
Thus far in reporting the findings of our project "Fifty Years After: Black Employment in the United States Under the Equal Employment Opportunity Commission," our analysis of what has happened to African American employment over the past half century has documented the importance of manufacturing employment to the upward socioeconomic mobility of Blacks in the 1960s and 1970s and the devastating impact of rationalization - the permanent elimination of blue-collar employment — on their socioeconomic mobility in the 1980s and beyond. The upward mobility of Blacks in the earlier decades was based on the Old Economy business model (OEBM) with its characteristic "career-with-one-company" (CWOC) employment relations. At its launching in 1965, the policy approach of the Equal Employment Opportunity Commission assumed the existence of CWOC, providing corporate employees, Blacks included, with a potential path for upward socioeconomic mobility over the course of their working lives by gaining access to productive opportunities and higher pay through stable employment within companies. It was through these internal employment structures that Blacks could potentially overcome barriers to the long legacy of job and pay discrimination.

* Professor of economics emeritus, University of Massachusetts; president of the Academic-Industry Research Network; Open Society Fellow; and Canadian Institute for Advanced Research Fellow.

${ }^{* *}$ Professor of economics emeritus, University of Massachusetts; research associate of the Academic-Industry Research Network.

${ }^{* * *} \mathrm{PhD}$ candidate in political science at Brown University; research associate of the Academic-Industry Research Network

The authors are grateful to the Institute for New Economic Thinking for funding this project and to Thomas Ferguson for many insightful comments. Samantha Gable provided research assistance.
\end{abstract}


In the 1960s and 1970s, the generally growing availability of unionized semiskilled jobs gave working people, including Blacks, the large measure of employment stability as well as rising wages and benefits characteristic of the lower levels of the middle class. The next stage in this process of upward socioeconomic mobility should have been-and in a nation as prosperous as the United States could have been - the entry of the offspring of the new Black blue-collar middle class into white-collar occupations requiring higher educations. Despite progress in the attainment of college degrees, however, Blacks have had very limited access to the best employment opportunities as professional, technical, and administrative personnel at U.S. technology companies. Since the 1980s, the barriers to African American upward socioeconomic mobility have occurred within the context of the marketization (the end of CWOC) and globalization (accessibility to transnational labor supplies) of high-tech employment relations in the United States. These new employment relations, which stress interfirm labor mobility instead of intrafirm employment structures in the building of careers, are characteristic of the rise of the New Economy business model (NEBM), as scrutinized in William Lazonick's 2009 book, Sustainable Prosperity in the New Economy? Business Organization and High-Tech Employment in the United States (Upjohn Institute).

In this paper, we analyze the exclusion of Blacks from STEM (science, technology, engineering, math) occupations, using EEO-1 employment data made public, voluntarily and exceptionally, for various years between 2014 and 2020 by major tech companies, including Alphabet (Google), Amazon, Apple, Cisco, Facebook (now Meta), Hewlett Packard Enterprise, HP Inc., Intel, Microsoft, PayPal, Salesforce, and Uber. These data document the vast over-representation of Asian Americans and vast under-representation of African Americans at these tech companies in recent years. The data also shine a light on the racial, ethnic, and gender composition of large masses of lower-paid labor in the United States at leading U.S. tech companies, including tens of thousands of sales workers at Apple and hundreds of thousands of laborers \& helpers at Amazon. In the cases of Hewlett-Packard, IBM, and Intel, we have access to EEO-1 data from earlier decades that permit in-depth accounts of the employment transitions that characterized the demise of OEBM and the rise of NEBM.

Given our findings from the EEO-1 data analysis, our paper then seeks to explain the enormous presence of Asian Americans and the glaring absence of African Americans in well-paid employment under NEBM. A cogent answer to this question requires an understanding of the institutional conditions that have determined the availability of qualified Asians and Blacks to fill these employment opportunities as well as the access of qualified people by race, ethnicity, and gender to the employment opportunities that are available. Our analysis of the racial/ethnic determinants of STEM employment focuses on a) stark differences among racial and ethnic groups in educational attainment and performance relevant to accessing STEM occupations, b) the decline in the implementation of affirmative-action legislation from the early 1980s, c) changes in U.S. immigration policy that favored the entry of well-educated Asians, especially with the passage of the Immigration Act of 1990, and d) consequent social barriers that qualified Blacks have faced relative to Asians and whites in accessing tech employment as a result of a combination of statistical discrimination against African Americans and their exclusion from effective social networks. 


\section{https://doi.org/10.36687/inetwp177}

JEL codes: D2, D3, D8, D91, E23, F22, F23, F66, G35, H11, H52, I2, J15, J21, J24, J31, J44, J53, J71. J82, L2, L63, M14, M5, N82, O15, O32, O36, P12

Key words: African American, Black. Asian, higher education, employment relations, equal employment opportunity, professionals, technology companies, Silicon Valley, Equal Employment Opportunity (EEO-1) data, social networks, employment discrimination. 


\section{Diversity in high tech?}

Since the 1980s, the inhabitants of the United States have witnessed a rising concentration of income among the richest households, a polarization of employment opportunity between a privileged portion of employees with higher educations and the rest of the labor force, and downward intergenerational socioeconomic mobility for those members of the labor force who have at most high school educations. In a series of INET working papers on the evolution of employment opportunity for African Americans over the past century, we have delved into the social, economic, and political forces that have shaped these trends from the perspective of the changing availability of middle-class jobs in the U.S. economy and access of Blacks to them. ${ }^{1}$

We have emphasized the centrality of employment relations at major business corporations for the availability of middle-class employment opportunities, focusing on the roles of educational attainment and work experience that enable individuals to access these opportunities. In Working Paper \#1 of our project, "How the Disappearance of Unionized Jobs Obliterated an Emergent Black Middle Class," we provide an overview of our findings on how from the early 1980s the rationalization, marketization, and globalization of corporate employment relations eroded the stable, well-paid blue-collar job opportunities in major U.S. corporations that a significant proportion of the Black labor force had begun to obtain in the 1960s and 1970s.

In Working Paper \#2, "Employment and Earnings of African Americans Fifty Years After: Progress?," we compile data on trends in education, employment, income, wealth, and health that provide a quantitative picture of the derailment of the engine of equal employment opportunity for Blacks that the Civil Rights Act of 1964 had sought, with some initial success, to set in motion.

In Working Paper \#3, "Employment Mobility and the Belated Emergence of the Black Middle Class," we focus on the types of employment opportunities that African Americans found in the industrial North and Midwest in their Great Migration from Southern agriculture from the 1910s to the 1960s. We then provide a detailed analysis of the upward mobility in the 1960s and 1970s of Blacks with no more than a high-school education to well-paid unionized employment opportunities, epitomized by semi-skilled operative jobs in the automobile industry. Antidiscrimination laws under Title VII of the 1964 Civil Rights Act with oversight by the Equal Employment Opportunity Commission (EEOC) supported this upward mobility for Blacks in the context of a growing demand for blue-collar labor and limited immigration to the United States.

\footnotetext{
${ }^{1}$ William Lazonick, Philip Moss, and Joshua Weitz, "How the Disappearance of Unionized Jobs Obliterated an Emergent Black Middle Class," Institute for New Economic Thinking Working Paper No. 1255, June 15, 2021, at https://www.ineteconomics.org/research/research-papers/how-the-disappearance-of-unionized-jobs-obliterated-an-emergentblack-middle-class; Philip Moss, William Lazonick, and Joshua Weitz, "Employment and Earnings of African Americans Fifty Years After: Progress?” Institute for New Economic Thinking Working Paper No. 129. July 13, 2020, at https://www.ineteconomics.org/research/research-papers/employment-and-earnings-of-african-americans-fifty-years-afterprogress; Joshua Weitz, William Lazonick, and Philip Moss, "Employment Mobility and the Belated Emergence of the Black Middle Class," Institute for New Economic Thinking Working Paper No. 143, January 2, 2021, at https://www.ineteconomics.org/research/research-papers/employment-mobility-and-the-belated-emergence-of-the-blackmiddle-class; William Lazonick, Philip Moss, and Joshua Weitz, "The Unmaking of a Black Blue-Collar Middle Class," Institute for New Economic Thinking Working Paper No. 159, May 20, 2021, at https://www.ineteconomics.org/research/research-papers/the-unmaking-of-the-black-blue-collar-middle-class.
} 
In Working Paper \#4, "The Unmaking of a Black Blue-Collar Middle Class," we analyze how from the late 1970s, the impact of global competition and the offshoring of manufacturing combined with the financialization of the corporation to decimate these stable and well-paid blue-collar jobs. From the early 1980s permanent plant closings and layoffs in massproduction industries became the new reality for America's blue-collar workers. Under the seniority provisions of the now beleaguered industrial unions, Blacks tended to be last hired and first fired.

As U.S.-based blue-collar jobs disappeared, U.S. business corporations and government agencies failed to make sufficient investments in the education and skills of the U.S. labor force to usher in a new era of upward socioeconomic mobility. This organizational failure left Blacks most vulnerable to downward mobility. Instead of retaining corporate profits and reinvesting in the productive capabilities of employees, major business corporations became increasingly focused on downsizing their blue-collar labor forces and distributing corporate cash to shareholders in the form of cash dividends and stock buybacks. Legitimizing massive distributions to shareholders was the flawed ideology that a company should be run to "maximize shareholder value" (MSV). ${ }^{2}$ This new ideology of financialized corporate governance went hand-in-glove with tax cuts for the rich and the withdrawal of government programs that, in the post-World War II decades, had supported the affordable access of working-class households to higher education as a platform for white-collar career employment.

At the same time, from the 1980s, as major U.S. corporations transitioned from the "Old Economy business model" (OEBM), characterized by a career with one company (CWOC), to the "New Economy business model" (NEBM), the paths of career employment dramatically changed. Replacing the OEBM norm of a career with one company (CWOC), NEBM emphasized interfirm labor mobility, advanced education, and social networks for building careers in well-paid white-collar occupations. Along with non-white Hispanics, Blacks found themselves at a distinct disadvantage relative to whites and Asians in accessing these New Economy middle-class employment opportunities. Eventually, the downward socioeconomic mobility experienced by blue-collar Blacks would also extend to devastating loss of well-paid and stable employment for those whites who lacked the higher educational qualifications now needed for entry into the type of white-collar career paths that could provide the continuous employment and higher income for attaining a middle-class living standard.

By the twenty-first century, general downward socioeconomic mobility had become a defining characteristic of American society, irrespective of race, ethnicity, or gender. ${ }^{3}$ Since the 1980s, the enemy of equal employment opportunity through upward socioeconomic mobility has been the pervasive corporate-governance ideology of MSV. For most Americans, of whatever race, ethnicity, and gender, MSV is the not-so-invisible hand that favors downsizing the labor force and distributing corporate cash to shareholders - a powerful

2 William Lazonick and Jang-Sup Shin, Predatory Value Extraction: How the Looting of the Business Corporation Became the US Norm and How Sustainable Prosperity Can Be Restored, Oxford University Press, 2020.

3 See Lazonick et, al., "How the Disappearance of Unionized Jobs Obliterated an Emergent Black Middle Class"; Lazonick et al., "The Unmaking of a Black Blue-Collar Middle Class." 
chokehold on the emergence of the stable and well-paid employment opportunities that are essential for sustainable prosperity. ${ }^{4}$

For reasons which we outline in this paper, whites have been vastly better positioned than Blacks to obtain higher education and employment experience for intergenerational upward mobility from blue-collar employment to white-collar employment. The exclusion of Blacks from access to the best employment opportunities that the U.S. economy has to offer is evident when we examine, as we do in this paper, the composition of employment at leading U.S. "tech" companies such as Alphabet (Google), Amazon, Apple, Cisco, Facebook, Intel, and Microsoft among others that exemplify NEBM.

An overview of the race/ethnicity/gender composition of employment in these types of companies can be found in a report "Diversity in High Tech," published by the EEOC in 2016. This document analyzes EEO-1 annual forms for 2014 on the race, ethnicity, and gender of their U.S. labor forces, submitted to the EEOC by companies employing 100 or more people in the United States. $^{5}$ As background to this analysis, the EEOC report provides a comparison of computer and internetworking occupations in 1997 and 2012, as shown in Figure V.1. From 1997, when the Internet boom was taking off, to 2012, the number of "high-tech" jobs in the United States grew from 2.2 million (1.6 percent of the civilian labor force) to 4.0 million (2.6 percent). ${ }^{6}$ Meanwhile the mix of tech jobs changed substantially. As the EEOC report puts it: "Some 2012 occupations, such as web developers and information security analysts, simply did not exist in 1997, while others have dramatically grown (programmers and software developers, computer and network support specialists) or shrunk (computer operators)."7

\section{Figure V.1: Computer and networking technology industry} occupations in the United States, 1997 and 2012

\begin{tabular}{|c|c|c|c|c|}
\hline & & & & 24,880 Computer \& information research scientists \\
\hline & & & & 34,350 Computer science teachers, postsecondary \\
\hline & & & & 71,560 Computer operators \\
\hline & & & & 72,670 Information security analysts \\
\hline & & & & 79,580 Computer hardware engineers \\
\hline & & & & 102,940 Web developers \\
\hline & & & & 111,590 Database administrators \\
\hline Computer science teachers, postsecondary & 21,260 & & & 137,890 Computer network architects \\
\hline Peripherial electr. data proc. equip. oper. & 25,930 & & & 167,980 Computer network support specialists \\
\hline Computer programmer aides & 63,240 & & & 185,730 Computer occupations, all other \\
\hline Database administrators & 82,600 & & & 309,740 Computer \& information systems managers \\
\hline All other computer & 82,630 & & & 316,790 Computer programmers \\
\hline Computer operators & 208,680 & & & 350,320 Network \& computer systems administrators \\
\hline Computer engineers & 252,230 & & & 391,700 Software developers,systems software \\
\hline Computer support specialists & 406,230 & & & 482,040 Computer systems analysts \\
\hline Computer programmers & 501,390 & & & 525,630 Computer user support specialists \\
\hline Systems analysts, electronic data processing & 530,420 & & & 586,340 Software developers, applications \\
\hline Total & $2,174,610$ & 1997 & $\underline{2012}$ & $3,951,730$ Total \\
\hline
\end{tabular}

Source: Reproduced from U.S. Equal Opportunity Employment Commission, "Diversity in High Tech."

\footnotetext{
4 William Lazonick, "Labor in the Twenty-First Century: The Top 0.1\% and the Disappearing Middle Class," in Christian E. Weller, ed., Inequality, Uncertainty, and Opportunity: The Varied and Growing Role of Finance in Labor Relations, Cornell University Press, 2015: 143-192; Lazonick and Shin, Predatory Value Extraction.

5 U.S. Equal Employment Opportunity Commission, "Diversity in High Tech," EEOC, May 2016, at https://www.eeoc.gov/special-report/diversity-high-tech.

${ }^{6}$ Data on the size of the civilian labor force can be found at Federal Reserve Board of St. Louis, "FRED Economic Data: Civilian Labor Force (CLF160V)," at https://fred.stlouisfed.org/series/CLF16OV.

${ }^{7}$ U.S. Equal Employment Opportunity Commission, “Diversity in High Tech,” p. 6.
} 
For 2014, the EEOC report focuses on employment in high-tech industries, defined as four-digit NAICS codes in which at least 25 percent of the total number of employees are "technologyoriented workers." 8 The report goes on to compare, as summarized in Table V.1, the race, ethnicity, and gender composition of the labor force in high tech with the entire U.S. industrial economy. In Table V.1, we have added to the EEOC's summary comparative statistics on the race, ethnicity and gender composition of the U.S. population, 21 years of age and over, in 2010.

\section{Table V.1: Racial, ethnic, and gender composition of the U.S. high-tech labor force compared with the entire U.S. industrial labor force, 2014, and shares of total U.S. population, 2010}

\begin{tabular}{|l|c|c|c|}
\hline \%, except total employment & $\begin{array}{c}\text { High-tech industries } \\
\text { only, 2014 }\end{array}$ & $\begin{array}{c}\text { All U.S. industries, } \\
\mathbf{2 0 1 4}\end{array}$ & $\begin{array}{c}\text { U.S. residential } \\
\text { population, 2010 (21 } \\
\text { years of age and over) }\end{array}$ \\
\hline Total employment & $5,341,599$ & $57,399,178$ & $221,319,000$ \\
\hline Women & 35.7 & 48.2 & 50.8 \\
\hline White & 68.5 & 63.5 & 67.5 \\
\hline Black & 7.4 & 14.4 & 11.5 \\
\hline Hispanic & 8.0 & 13.9 & 13.9 \\
\hline Asian & 14.0 & 5.8 & 4.9 \\
\hline American Indian or Native Alaskan & 0.4 & 0.6 & 0.5 \\
\hline Native Hawaiian or Pacific Islanders & 0.3 & 0.4 & 0.1 \\
\hline Two or more races & 1.3 & 1.5 & 1.5 \\
\hline
\end{tabular}

Note: Hispanics may also be included in a race classification.

Sources: U.S. Equal Opportunity Employment Commission, "Diversity in High Tech," p. 16; National Science Board, Revisiting the STEM Workforce, National Science Foundation, 2015, at https://nsf.gov/pubs/2015/nsb201510/nsb201510.pdf, p. 23.

Having determined that Blacks and Hispanics were severely underrepresented in high-tech industries, the EEOC report provides comparative information which shows that companies in these industries employed a far higher proportion of people in high-paid positions as executives, managers, and professionals as well as in medium-paid employment (mainly technicians) than industry in general, as shown in Table V.2. Taken together, the top four occupational categories in Table V.2 employed 69.6 percent of all workers in high tech but only 36.5 percent in all U.S. industries, with the most extreme difference among professionals (43.5 percent versus 19.8 percent). It is accession to these higher-paid positions that typically enable upward socioeconomic mobility, with inclusion as a technology "professional" - that is, as a scientist or engineer-offering the greatest scope for advanced employment opportunity.

The next step in the EEOC report is to compare the racial and ethnic composition of employment in the four upper-level occupations in high-tech and all industries, as shown in Table V.3. In high tech in 2014, whites and Asians were over-represented and Blacks and Hispanics underrepresented in all four upper-level occupational categories, with whites showing the greatest

\footnotetext{
${ }^{8}$ In the EEOC study, the high-tech industries are 3254 (Pharmaceutical and Medicine Manufacturing), 3333 (Commercial and Service Industry Machinery Manufacturing), 3341 (Computer and Peripheral Equipment Manufacturing), 3342 (Communications Equipment Manufacturing), 3343 (Audio and Video Equipment Manufacturing), 3344 (Semiconductor and Other Electronic Component Manufacturing). 3345 (Navigational, Measuring, Electrometrical, and Control Instruments Manufacturing), 3346 (Manufacturing and Reproducing Magnetic and Optical Media), 3364 (Aerospace Products and Parts Manufacturing), 3391 (Medical Equipment and Supplies Manufacturing), 5112 (Software Publishers), 5179 (Other Telecommunications), 5191 (Other Information Services), 5413 (Architectural, Engineering, and Related Services), 5415 (Computer Systems Design and Related Services), 5417 (Scientific Research and Development Services), 5419 (Other Professional, Scientific, and Technical Services).
} 
dominance in the officials and managers categories and Asians in the professionals category. The greatest proportional access to these upper-level jobs for Blacks and Hispanics was as technicians, but in high-tech industries that occupational category provided only 19 percent of the number of jobs available in the professionals category and were generally lower paid. ${ }^{9}$

Table V.2: Occupational distribution, high-tech industries and all U.S. industries, 2014

\begin{tabular}{|l|c|c|}
\hline & $\begin{array}{c}\text { High-tech } \\
\text { industries } \\
\text { only, \% }\end{array}$ & $\begin{array}{c}\text { All U.S. } \\
\text { industries, } \\
\%\end{array}$ \\
\hline Executives, senior officials and managers & 2.61 & 1.58 \\
\hline First/mid officials and managers & 14.25 & 9.51 \\
\hline Professionals & 43.47 & 19.76 \\
\hline Technicians & 9.22 & 5.66 \\
\hline Sales workers & 6.39 & 12.32 \\
\hline Clerical workers & 9.83 & 12.84 \\
\hline Craft workers & 4.39 & 5.61 \\
\hline Operatives & 7.62 & 10.09 \\
\hline Laborers & 1.48 & 7.07 \\
\hline Service workers & 0.73 & 15.50 \\
\hline Total employment & 100.00 & 100.00 \\
\hline
\end{tabular}

Source: U.S. Equal Opportunity Employment Commission, "Diversity in High Tech," p. 17.

Table V.3: Racial and ethnic composition of upper-level occupational categories in high-tech industries and all U.S. industries, 2014

\begin{tabular}{|c|c|c|c|c|c|}
\hline & $\begin{array}{c}\text { White } \\
\%\end{array}$ & $\begin{array}{c}\text { Black } \\
\%\end{array}$ & $\begin{array}{c}\text { Hispanic } \\
\%\end{array}$ & $\begin{array}{c}\text { Asian } \\
\%\end{array}$ & $\begin{array}{l}\text { Number of } \\
\text { employees }\end{array}$ \\
\hline \multicolumn{6}{|l|}{ High tech only } \\
\hline Executives, senior officials and managers & 83.31 & 1.92 & 3.11 & 10.55 & 139,575 \\
\hline First/mid officials and managers & 76.53 & 4.12 & 4.91 & 12.98 & 761,380 \\
\hline Professionals & 68.03 & 5.27 & 5.28 & 19.49 & $2,321,969$ \\
\hline Technicians & 68.58 & 9.01 & 10.23 & 9.68 & 452,359 \\
\hline \multicolumn{6}{|l|}{ All U.S. industries } \\
\hline Executives, senior officials and managers & 86.97 & 3.13 & 3.87 & 4.88 & 833,367 \\
\hline First/mid officials and managers & 77.53 & 7.12 & 7.43 & 6.31 & $4,766,041$ \\
\hline Professionals & 72.89 & 7.64 & 5.79 & 11.74 & $10,534,689$ \\
\hline Technicians & 67.17 & 13.79 & 10.09 & 6.56 & $2,870,353$ \\
\hline
\end{tabular}

Source: U.S. Equal Opportunity Employment Commission, "Diversity in High Tech," p. 20.

For all U.S. industries, whites were even more dominant in all occupations except for the technicians category, in which Blacks were somewhat over-represented compared with their share of the U.S. population as a whole (see Table V.1). Asians had markedly lower shares in all four categories compared with their representation in high tech alone (although even in all industries Asians were over-represented as professionals). Note that for all industries, the numbers employed as technicians, the category in which Blacks experienced their best representation among the upper-level occupational categories, were only 27 percent of the

9 The Obama administration sought to have companies report pay data along with employment data in their annual EE0-1 submissions, but the Trump administration reversed this decision. Nevertheless, under court order, EEOC collected pay data for 2016 and 2017. U.S. Equal Opportunity Employment Commission, "EEOC announces analysis of EEO-1 Component 2 Pay Data Collection," EEOC press release, July 16, 2020, at https://www.eeoc.gov/newsroom/eeoc-announces-analysis-eeo-1component-2-pay-data-collection. 
number of professionals jobs and 51 percent of the number of jobs in the two "officials and managers" categories combined.

The EEOC report then narrows in on the representation of Blacks and Hispanics in employment at high-tech companies in the San Francisco Bay Area, including San Francisco Metropolitan Area (SFMA, comprised of San Francisco, Oakland, and Fremont) and Santa Clara County (SCC), the heart of Silicon Valley (see Table V.4). After observing that "African Americans and Hispanics were disproportionately fewer in leadership positions and in technology jobs in the high-tech sector nationwide," the EEOC report goes on to say: "These groups had negligible employment representation in high tech industries in the San Francisco Bay Area."10

Table V.4: Racial, ethnic, and gender representation in high-tech industries located in two geographic areas within the San Francisco Bay Area, 2014

\begin{tabular}{|l|c|c|}
\hline$\%$ except for total employment & $\begin{array}{c}\text { San Francisco } \\
\text { Metropolitan Area }\end{array}$ & $\begin{array}{c}\text { Santa Clara County } \\
\text { (includes Silicon } \\
\text { Valley) }\end{array}$ \\
\hline Total employment & $\mathbf{1 9 8 , 2 7 5}$ & $\mathbf{2 5 7 , 3 4 2}$ \\
\hline Women & 36.68 & 28.91 \\
\hline White & 54.56 & 44.11 \\
\hline Black & 3.35 & 2.08 \\
\hline Hispanic & 6.66 & 5.93 \\
\hline Asian & 32.07 & 45.65 \\
\hline American Indian or Native Alaskan & 0.28 & 0.22 \\
\hline Native Hawaiian or Pacific Islanders & 0.71 & 0.50 \\
\hline Two or more races & 2.07 & 1.50 \\
\hline \multicolumn{2}{|l|}{ Source: U.S. Equal Opportunity Employment Commission, "Diversity in High Tech," p. 20. }
\end{tabular}

Yet for decades the Bay Area has been, as it remains, the most dynamic location for the growth of technology firms. ${ }^{11}$ Not only do Blacks find fewer employment opportunities in high-tech than in industry in general; they also find fewer employment opportunities in the very geographic location in which high tech does best. Whereas Blacks were 7.4 percent of employees in hightech industries nationwide (see Table V.1), they were only 3.4 percent of employees at high-tech firms in SFMA and 2.1 percent in SCC. Note also the extraordinarily high proportion of Asian employees in the San Francisco Bay Area, and especially in SCC (and hence Silicon Valley). Nationwide, Asians were 14.0 percent of employees in high-tech industries, but 32.1 percent in the high-tech companies of SFMA and 45.7 percent-even higher than the proportion for whites - in SCC. In contrast, the under-representation of women in high-tech industries was about the same in SFMA as nationwide, although female under-representation was worse in SCC.

Table V.5 shows the proportional distribution by race and ethnicity of the employees in Table V.4 for the four upper-level occupational categories. Although, as can be seen in Table V.5, representation of Blacks among technicians was 6.6 percent of that occupational category in

\footnotetext{
${ }^{10}$ U.S. Equal Employment Opportunity Commission, "Diversity in High Tech,” p. 15.

${ }^{11}$ See, for example, Richard Florida, "The extreme geographic inequality of high-tech venture capital," CityLab, March 27, 2018, at https://www.citylab.com/life/2018/03/the-extreme-geographic-inequality-of-high-tech-venture-capital/552026/; Noah Smith, "Venture capital needs some geographic diversity," Bloomberg Opinion, August 28, 2018, at https://www.bloomberg.com/opinion/articles/2018-08-28/venture-capital-needs-some-geographic-diversity.
} 
SFMA and 7.8 percent in SCC, these proportions were both lower than the 9.0 percent for Black representation among technicians in high-tech industry nationwide (see Table V.3). And among the other three upper-level occupational categories shown in Table V.5, proportional representations of Blacks were much lower than the nationwide percentages in high tech. The 5.3 percent share of Blacks as professionals in high-tech industries nationwide was itself a large under-representation of Blacks in the U.S. population. In SFMA, Blacks were only 2.5 percent of professionals, and in SCC, just 1.5 percent. The SFMA and SCC figures measure "the negligible employment representation [for Blacks] in high tech industries in the San Francisco Bay Area" to which the EEOC report refers.

Table V.5: Racial and ethnic composition of upper-level occupational categories in San Francisco Metropolitan Area and Santa Clara County, 2014

\begin{tabular}{|l|r|r|r|r|r|}
\hline & $\begin{array}{c}\text { White } \\
\%\end{array}$ & $\begin{array}{c}\text { Black } \\
\%\end{array}$ & $\begin{array}{c}\text { Hispanic } \\
\%\end{array}$ & $\begin{array}{c}\text { Asian } \\
\%\end{array}$ & $\begin{array}{c}\text { Other } \\
\%\end{array}$ \\
\hline \multicolumn{1}{|c|}{ San Francisco Metropolitan Area } & & & & & \\
\hline Executives, senior officials and managers & 76.41 & 1.16 & 2.79 & 17.86 & 1.78 \\
\hline First/mid officials and managers & 62.43 & 2.31 & 4.69 & 28.25 & 2.32 \\
\hline Professionals & 52.59 & 2.45 & 4.99 & 37.20 & 2.77 \\
\hline Technicians & 40.08 & 6.59 & 12.38 & 36.54 & 4.41 \\
\hline \multicolumn{1}{|c|}{ Santa Clara County } & & & & \\
\hline Executives, senior officials and managers & 61.90 & 0.86 & 3.14 & 32.92 & 1.18 \\
\hline First/mid officials and managers & 53.70 & 1.48 & 4.52 & 38.49 & 1.81 \\
\hline Professionals & 39.32 & 1.52 & 3.97 & 51.15 & 4.04 \\
\hline Technicians & 41.03 & 7.82 & 11.91 & 34.69 & 3.55 \\
\hline
\end{tabular}

In 2014, therefore, Silicon Valley - the most important high-tech industrial district in the United States - was not a good place for African Americans to find employment. The EEOC report's findings on the dearth of Black, as well as Hispanic, employment opportunity in Silicon Valley had been previously noticed. In 1998, in the midst of the Internet boom, two journalists, Julia Angwin and Laura Castaneda, published an article in the San Francisco Chronicle, "The Digital Divide: High-tech boom a bust for blacks, Latinos." Their report was based on EEO-1 data, obtained from the Department of Labor under a Freedom of Information Act request, on the diversity of employment at 33 technology companies in and around Silicon Valley. ${ }^{12}$ These companies included, among the largest, Intel (30,003 employees), Seagate Technologies $(12,027)$, Oracle $(11,773)$, Sun Microsystems (11,385), Silicon Graphics $(7,586)$, and Apple $(7,538)$. The journalists had found that the employees of the 33 companies, taken together, were "about 4 percent black and 7 percent Latino_-even though blacks and Latinos make up 8 percent and 14 percent of the Bay Area labor force, respectively. The blacks and Latinos who do work at these companies are far more likely than whites to hold factory, service and support jobs, and less likely than whites to hold managerial and professional jobs."

Table V.6 shows the distribution across occupational categories of employees by racial or ethnic group at the 33 companies. Note that, in the journalists' summation of the data, the "professionals" category includes technicians and sales workers, and hence is a much broader

\footnotetext{
12 Julia Angwin and Laura Castaneda, "The Digital Divide: High-tech boom a bust for blacks, Latinos," San Francisco Chronicle, May 4, 1998, at https://www.sfgate.com/news/article/The-Digital-Divide-High-tech-boom-a-bust-for3007911.php;a;sp, published in US Black Engineer and Information Technology, 22,2,1998: 28-20, $32,34$.
} 
category than Professionals as entered on EEO-1 reports. ${ }^{13}$ Table V.6 shows that Blacks and Latinos were not only under-represented among all employees but also much more concentrated than whites and Asians in blue-collar and clerical jobs. The broad "professionals" category included 32,557 whites, 14,485 Asians, 2,706 Latinos, and 1,550 Blacks.

Based on "hundreds of interviews conducted over six months with Silicon Valley firms, black and Latino high-tech executives, academics, government officials and community activists," Angwin and Castaneda proposed five reasons to explain why Blacks and Latinos were being left behind: 1) a deficit in math and science education; 2) weak enforcement of affirmative-action laws; 3) insufficient firm recruiting at job fairs and college campuses with large Black and Latino populations; 4) poor engagement of Blacks and Latinos in the social networks through which tech personnel gain access to employment opportunities and career promotions; and 5) employment discrimination, fueled by racism, in high-tech industries. Some two decades later, as we report later in this paper, all five of these reasons remain in force as obstacles to Black employment in Silicon Valley.

Table V.6: Distribution of employees by race and ethnicity across occupational categories at 33 Silicon Valley companies, 1998

\begin{tabular}{|l|c|c|c|c|}
\hline & Whites & Asians & Blacks & Latinos \\
\hline Number of employees & 46,592 & 22,493 & 1,870 & 5,882 \\
\hline Officials/managers, \% & 22 & 10 & 12 & 9 \\
\hline "Professionals" (see note), \% & 67 & 66 & 54 & 46 \\
\hline Factory/support staff, \% & 12 & 24 & 34 & 45 \\
\hline
\end{tabular}

Note: According to Angwin and Castaneda, "Professionals include positions that require four-year degrees, and sales and technical jobs that require a two-year degree.

Factory/support staff includes clerical and service workers as well as laborers, operators, and craftworkers."

Source: Angwin and Castaneda, "The Digital Divide."

\section{Insights from EEO-1 employment reports for tech companies}

With the emergence of Silicon Valley as the apparent center of the economic universe in the Internet boom, publicity concerning the stark "digital divide" fueled social activism. In the winter of 1999, Reverend Jesse Jackson, head of the Rainbow PUSH Coalition, was in San Jose, California as the guest of the recently formed Coalition for Fair Employment in Silicon Valley. Concerned with discrimination against Blacks, the Fair Employment group had found that only 175 of 1,434 high-tech companies in the Bay Area which, as federal contractors, should have filed reports on their hiring practices with the Department of Labor, had in fact done so. Jackson criticized U.S. technology companies for importing workers from abroad on H-1B visas while neglecting the employment of qualified minorities in the United States. ${ }^{14}$ The Rainbow PUSH Coalition opened a Silicon Valley office and, as part of its "Silicon Valley Project," spent $\$ 51,000$ to buy $\$ 1,000$ in shares of each of 51 high-tech companies in order to, as Jackson put it, "negotiate with the companies" as shareholders to include more minority members on corporate boards. ${ }^{15}$

\footnotetext{
${ }^{13}$ We sought, without success, to secure access to the underlying EEO-1 forms used in the Angwin-Castaneda study.

14 "Jesse Jackson visits Silicon Valley, urges jobs for minorities," Associated Press Newswires, March 1, 1999.

15 Sarah Lubman, "Jesse Jackson says Silicon Valley boardrooms must reflect greater diversity," San Jose Mercury News, April $13,1999$.
} 
The Silicon Valley Project held its first Digital Connections 2000 Conference in May 2000, with CEOs of AMD, Cisco, Hewlett-Packard (HP), and Intel reportedly in attendance. The Conference announced "a three-to-five year plan for the high tech industry to educate, train, prepare, and, employ 200,000 young people in local communities." Intel CEO Craig Barrett, whose company donated $\$ 100,000$ to the Conference, declared: "No one program or one company can solve this overnight. We will make progress through collaboration and cooperation - with Reverend Jackson's team, with other committed companies and with our local partners in the community." 16

The Silicon Valley Project held two subsequent conferences in April 2001 and April 2002. With the tech industry in a deep downturn, however, the Project did not push its agenda at any of the annual shareholder meetings of the 51 companies in which it held shares. John Templeton, the founder of the Coalition for Fair Employment in Silicon Valley, which had been instrumental in the launching of the Silicon Valley Project, apparently did not participate in its three conferences, reportedly complaining that "Jackson undermined the plan to raise diversity issues at shareholder meetings by being too cozy with the companies he set out to pressure." 17 Another news report cited Templeton as stating that a conference "with tech CEOs is not going to help if there is no follow-up or accountability. If Microsoft and Intel are paying for the conference, then you're going to be dealing with their agenda and meeting your own short-term publicity needs." 18

After the Digital Connections 2000 Conference, HP put $\$ 5$ million over three years into the East Palo Alto Digital Village program "to assist K-12 students at school, including one-to-one elearning and scholarships through HP's Diversity in Education program; assistance to small businesses to use the Internet to manage and market their businesses; and a community portal to allow collaboration and e-commerce transactions among residents, city government, small businesses, non-profits, churches and other community organizations." 19 HP then launched similar programs in other low-income areas, including Southern California and East Baltimore, and also implemented the "Digital Village" model in Ghana, France, and South Africa. ${ }^{20}$ In April 2003, HP hosted an event at the East Palo Alto City Hall to celebrate the third anniversary of the Digital Village program, with community leaders, HP executives, and Jesse Jackson as speakers. ${ }^{21}$

Yet, by 2005, the Silicon Valley Project was in a state of suspension-but, as it turned out, far from moribund. After a hiatus of almost a decade, in March 2014, Jackson was at the annual

\footnotetext{
${ }^{16}$ Martha Mendoza, "High-tech CEOs pledge to diversify work forces," Associated Press, May 3, 2000.

${ }^{17}$ Sarah Lubman, "Jesse Jackson, high-tech sector sees many changes since gaining board access," San Jose Mercury News, April 23, 2002.

${ }^{18}$ V. Dion Haynes, "High-tech heavyweights offer advice to minority business people," Chicago Tribune, April $26,2002$.

${ }^{19} \mathrm{HP}$ press release, "HP pioneers new approach to social venture philanthropy; Two communities join East Palo Alto in becoming digitally connected with \$5 million each in HP resources," M2 Presswire, February 14, 2001.

${ }^{20} \mathrm{HP}$ press release, "HP's pioneering approach to social venture philanthropy goes global; Communities in Ghana, France and South Africa Selected as HP Digital Villages," M2 Presswire, October 11, 2001.

21 HP press release, "Celebrates three years of community/high-tech collaboration; \$5 million HP grant achieving goal of sustainable economic and educational development," Associated Press Newswires, April 29, 2003. See also HP press release, "East Palo Alto celebrates community milestones achieved through \$5 million HP Digital Village program grant; Mayor Duane Bay proclaims ‘HP Digital Village Day',’ Business Wire, April 23, 2002.
} 
shareholder meeting of HP, ${ }^{22}$ as the Rainbow PUSH Coalition relaunched what was now called the Silicon Valley Digital Connections Project "to expand the participation of Blacks and people of color-commensurate with our consumer base and population-in all dimensions of the technology industry." ${ }^{23}$ According to the New York Times coverage of the HP meeting: "Besides HP, both before and during the meeting, Mr. Jackson cited Twitter, Google, Facebook, Apple, among other companies, as places needing greater minority employment and leadership." 24

During May, Jackson attended the annual shareholder meetings of eBay, ${ }^{25}$ Google,${ }^{26}$ and Facebook, ${ }^{27}$ demanding that these companies make public their annual EEO-1 employment reports to the EEOC. At the Facebook meeting, Jackson asked: "Will Facebook voluntarily and publicly release [its] EEO-1 report?" Sheryl Sandberg, the company's chief operating officer, gave an evasive and convoluted response: "We believe, as you do, that transparency is really important, and we're on a path to get there. We're looking at our numbers internally. We're seeing growth already from what we're doing, and we would like to be on a path to share them both internally and eventually externally."28

Sandberg's treatment of the request for data contrasted starkly with the straightforward mea culpa that Jackson had heard at the Google meeting the week before. Responding to a prearranged speech by Jackson at the beginning of the Q\&A session, David Drummond, an African American executive in charge of Google public policy, said: "Many companies in [Silicon Valley] have been reluctant to divulge that data, including Google, and, quite frankly, we are wrong about that." Drummond promised the release of the EEO-1 report "next month," and less than two weeks later Google made the report public. ${ }^{29}$ This breakthrough won praise from Jackson, who issued a statement: "We believe it is time for other tech companies to follow Google's lead. We challenge them to also voluntarily release their Equal Employment Opportunity Data/Reports." 30

Gradually, a number of other tech companies followed suit. In June, Yahoo released its EEO-1 report, ${ }^{31}$ and by the end of 2014 eBay, Facebook, and LinkedIn had done so as well. ${ }^{32}$ In December, Jackson attended the Microsoft annual meeting, ${ }^{33}$ and a month later the company made its EEO-1 report public. ${ }^{34}$ Jackson was at the Apple meeting in March 2015, ${ }^{35}$ and in

\footnotetext{
${ }^{22}$ Quentin Hardy, “Jesse Jackson confronts Silicon Valley,” New York Times, March 19, 2014, at https://bits.blogs.nytimes.com/2014/03/19/jesse-jackson-confronts-silicon-valley/.

23 PRC Silicon Valley, at http://www.rainbowpushsv.org/about/.

${ }^{24}$ Ibid.

25 "eBay Annual Shareholder Meeting - Final," CQ FD Disclosure, May 13, 2014.

26 "Google to release diversity data about workforce," Deccan Chronicle, May 14, 2014.

27 "Facebook Annual Shareholder Meeting - Final," CQ FD Disclosure, May 22, 2014.

${ }^{28}$ Ibid. When Jackson posed the same question to Sandberg again, she repeated much the same noncommittal response.

${ }^{29}$ Martha Mendoza, "Google's diversity data reveals largely white, male workforce but striving for change," Associated Press, May 29, 2014.

30 John Ribeiro, "Google concedes in diversity data that employees mainly male and white," All Africa, May 29, 2014.

${ }^{31}$ John Sailors, "Yahoo reveals diversity data: It's mostly white and male," San Francisco Business Times Online," June 18, 2014.

32 Jessica Guynn, “Apple, Amazon refuse to release federal diversity data," USA Today, December 8, 2014.

${ }^{33}$ Bill Rigby, "Former CEO Ballmer, activist Jesse Jackson enliven Microsoft meeting," Reuters News, December 3, 2014; Jessica Guynn, "Diversity takes center stage at Microsoft annual meeting," USA Today, December 3, 2014.

34 Jacob Demmitt, "Microsoft quietly makes good on promise to reveal diversity stats, posts Equal Employment data," Dallas Business Journal Online, January 2, 2015.

35 Jon Swartz, "Rev. Jackson to Apple: March for diversity not over," USA Today, March 10, 2015.
} 
August Apple released its EEO-1 report for 2014. ${ }^{36}$ The process was repeated at Amazon in June. ${ }^{37}$ In 2016, the Center for Investigative Reporting's "Reveal" project joined the effort to persuade tech companies to release their EEO-1 reports. ${ }^{38}$ Table V.7 documents (to our knowledge) all of the tech company EEO-1 submissions that had been made public for 20132020 as of December 2021.

Table V.7: Public releases of EEO-1 reports by tech companies, 2013-2020

\begin{tabular}{|c|c|c|c|c|c|c|c|c|}
\hline & 2013 & 2014 & 2015 & 2016 & 2017 & 2018 & 2019 & 2020 \\
\hline 23andme & & & & $\mathbf{x}$ & & & & \\
\hline Adobe & & & $x$ & $x$ & $\mathbf{x}$ & $x$ & $x$ & $x$ \\
\hline Airbnb & & $\mathbf{x}$ & $\mathbf{x}$ & $x$ & $\mathbf{x}$ & $\mathbf{x}$ & & \\
\hline Amazon & & $x$ & $x$ & $x$ & & & $x$ & $x$ \\
\hline Apple & & $\mathbf{x}$ & $\mathbf{x}$ & $\mathbf{x}$ & $\mathbf{x}$ & $\mathbf{x}$ & & $\mathbf{x}$ \\
\hline Applied Materials & & & & $\mathbf{x}$ & & $\mathbf{x}$ & & \\
\hline Cisco & & $\mathbf{x}$ & $x$ & $x$ & & $\mathbf{x}$ & & \\
\hline eBay & & $\mathbf{x}$ & & $x$ & $\mathbf{x}$ & $x$ & $x$ & $\mathbf{x}$ \\
\hline Facebook & $\mathbf{x}$ & $\mathbf{x}$ & $x$ & $x$ & $\mathbf{x}$ & $\mathbf{x}$ & $x$ & $\mathbf{x}$ \\
\hline Google (Alphabet) & & $\mathbf{x}$ & & $x$ & $\mathbf{x}$ & $x$ & & \\
\hline Hewlett-Packard Enterprise & & & & $\mathbf{x}$ & & & & \\
\hline HP & & & & $\mathbf{x}$ & & & & \\
\hline Intel & & $\mathbf{x}$ & $x$ & $\mathbf{x}$ & $\mathbf{x}$ & $\mathbf{x}$ & $\mathbf{x}$ & \\
\hline Intuit & & & & $\mathbf{x}$ & & & & \\
\hline Juniper Networks & & & & & & $\mathbf{x}$ & & $\mathbf{x}$ \\
\hline LinkedIn & $\mathbf{x}$ & $\mathbf{x}$ & & $\mathbf{x}$ & & & & \\
\hline Lyft & & & & $\mathbf{x}$ & $\mathbf{x}$ & & & $\mathbf{x}$ \\
\hline Microsoft & & $x$ & $x$ & $x$ & $\mathbf{x}$ & $x$ & $x$ & $\mathbf{x}$ \\
\hline Mobilelron & & & & $\mathbf{x}$ & & & & \\
\hline Netflix & & $\mathbf{x}$ & $\mathbf{x}$ & $x$ & $x$ & $\mathbf{x}$ & & \\
\hline Nvidia & & & & $\mathbf{x}$ & & $\mathbf{x}$ & & $x$ \\
\hline Oracle & & & & & & $\mathbf{x}$ & & $\mathbf{x}$ \\
\hline Palantir & & & $x$ & & & & & \\
\hline Palo Alto Networks & & & & & $x$ & $x$ & & \\
\hline Pandora Media & & & & & $\mathbf{x}$ & & & \\
\hline Paypal & & & $\mathbf{x}$ & $\mathbf{x}$ & $\mathbf{x}$ & $\mathbf{x}$ & & \\
\hline Pinterest & & & & $\mathbf{x}$ & & & & \\
\hline Salesforce & & & & $\mathbf{x}$ & $\mathbf{x}$ & $\mathbf{x}$ & & \\
\hline Slack & & & & & $\mathbf{x}$ & $\mathbf{x}$ & & \\
\hline Splunk & & & $\mathbf{x}$ & & $\mathbf{x}$ & & & \\
\hline Square & & & & $\mathbf{x}$ & & & & \\
\hline Twitter & & $\mathbf{x}$ & & $x$ & & & & \\
\hline Uber & & & & $\mathbf{x}$ & $\mathbf{x}$ & & & \\
\hline View & & & & $x$ & & & & \\
\hline Yahoo & $\mathbf{x}$ & & $\mathbf{x}$ & & & & & \\
\hline Yelp & $\mathbf{x}$ & & & & & & & \\
\hline
\end{tabular}

Note: $\mathrm{x}$ in the cell means that the EEO-1 report is publicly available and in possession of the authors.

Sources: Reveal from the Center for Investigative Reporting, at https://s3-us-west-1.amazonaws.com/appsstaging-revealnews-org/silicon-valley-diversity-list/index.html; Google and Factiva searches.

${ }^{36}$ Rupert Neate, “Apple's senior executives are 70\% white men, diversity filing reveals,” The Guardian, August 4, 2015.

${ }^{37}$ Jacob Demmitt, "85 percent of Amazon's black U.S. workers hold unskilled jobs," Puget Sound Business Journal Online, June 11, 2015.

${ }^{38}$ Reveal from the Center for Investigative Reporting, “Silicon Valley diversity data: Who released theirs, who didn't?" October 19, 2017, at https://s3-us-west-1.amazonaws.com/apps-staging-revealnews-org/silicon-valley-diversity-list/index.html/. See also Kavya Vaghul, "A small fraction of corporations share diversity data, but disclosure is rapidly on the rise," Just Capital, January 19, 2021, at https://justcapital.com/news/a-small-fraction-of-corporations-share-diversity-data-but-disclosure-israpidly-on-the-rise/. 
The availability of diversity data at the company level is important for the analysis of the institutional and organizational barriers to the upward mobility of Blacks into well-paid whitecollar employment - in the case of high tech, as engineers as well as managers. Increasingly since the 1980s upward mobility has entailed access to employment opportunities at the whitecollar level, with higher education as an essential requirement. This occupational locus of upward mobility was also important in the post-World War II decades, but with the disappearance of well-paid and secure jobs that require only high-school education, upward mobility within the ranks of white-collar employment requiring higher education has become the only path to the middle class available on a mass scale. And tech is a key sector in which those upwardly mobile employment opportunities are available.

In Working Paper \#3, we drew heavily on the Wharton studies of the "racial policies of American industry," carried out in the late 1960s and early 1970s, which focused on the increasing employment of Blacks in unionized semiskilled blue-collar jobs that permitted access to a middle-class standard of living. ${ }^{39}$ At the time, a blue-collar worker could potentially climb the internal job ladder within a company from unskilled laborer to semiskilled operative and perhaps even to skilled craft worker. Union bargaining provided these upwardly mobile workers with access to the lower range of middle-class incomes, including company-funded healthcare and defined-benefit retirement pensions as well as, by virtue of union seniority provisions in collective-bargaining, employment security.

In the 1980s and 1990s, rationalization and globalization diminished the availability of these types of employment paths to the middle class for high-school-educated blue-collar workers. Since then, a college education has become, in general, a requirement for accessing well-paid work. With the marketization of the employment of college-educated white-collar workers integral to the rise of NEBM in these decades and beyond, interfirm mobility, mediated by social networks, became much more important to the pursuit of a career. It was the type of "New Economy" tech companies listed in Table V.7, along with an erstwhile "Old Economy" company such as Hewlett Packard (now divided into HP Inc. and Hewlett Packard Enterprise) that from the late 1990s made the transition to NEBM, that turned these marketized types of white-collar employment relations into the new American norm. ${ }^{40}$ As we shall see, the publicly released EEO-1 data of the companies listed in Table V.7 demonstrate quite clearly that in the last half of the 2010s Blacks remained vastly under-represented at tech companies, particularly in the "professionals" as well as "officials and managers" occupational categories.

Prior to the renewed Rainbow PUSH Coalition campaign of 2014, it was rare for a company to make the data on the EEO-1 information publicly available of its own accord. One exception was IBM. The company published its EEO-1 data for the years 1996 through 2008 on its website and, for some years, in its Corporate Responsibility Report (issued annually since 2002). IBM's EEO1 data are displayed in Table V.8 (for every four years to simplify the presentation), documenting the diversity of the company's U.S.-based labor force from 1996 to 2008. IBM has not made public any of its subsequent EEO-1 submissions.

\footnotetext{
${ }^{39}$ Weitz et al., "Employment Mobility and the Belated Emergence of the Black Middle Class."

${ }^{40}$ William Lazonick, Sustainable Prosperity in the New Economy? Business Organization and High-tech Employment in the United States, W. E. Upjohn Institute for Employment Research, 2009, Chs. 2-3, at https://doi.org/10.17848/9781441639851.
} 
As shown in Table V.8, in the 2000s IBM dramatically downsized its U.S.-based labor force; it had risen from 125,618 in 1996 to a peak of 153,587 in 2000 before declining to 120,227 in 2008. Meanwhile, in the 2000s, IBM was rapidly increasing its foreign labor force from 115,000 in 1996 to 163,000 in 2000 to 278,000 in 2008. ${ }^{41}$ Total African American employment at IBM increased from 12,412 in 1996 to 13,596 in 2000 but then fell to only 8,973 in 2008. Although IBM's worldwide employment increased by 61 percent from 1996 to 2008, its U.S.-based labor force fell by over four percent and its Black labor force declined by almost 28 percent.

Table V.8: Blacks in IBM's U.S.-based labor force, 1996, 2000, 2004, and 2008

\begin{tabular}{|c|c|c|c|c|}
\hline & 1996 & 2000 & 2004 & 2008 \\
\hline \multicolumn{5}{|c|}{ Total number of IBM employees in USA } \\
\hline & 125,618 & 153,587 & 139,899 & 120,227 \\
\hline \multicolumn{5}{|c|}{ IBM's U.S. employees as \% of worldwide employees } \\
\hline & 52.2 & 48.6 & 42.5 & 32.8 \\
\hline \multicolumn{5}{|c|}{ Number of Black IBM employees in USA, by occupation } \\
\hline Officials/Mgrs & 1,149 & 1,639 & 1,018 & 927 \\
\hline Professionals & 3,641 & 4,838 & 4,569 & 3,347 \\
\hline Technicians & 834 & 1,222 & 1,044 & 799 \\
\hline Marketing & 1,248 & 3,050 & 2,814 & 2,853 \\
\hline Office/Clerical & 1,905 & 2,138 & 1,548 & 885 \\
\hline Craft Workers & 161 & 349 & 95 & 84 \\
\hline Operatives & 3,474 & 720 & 187 & 78 \\
\hline All Black employees in USA & 12,412 & 13,956 & 11,275 & 8,973 \\
\hline \multicolumn{5}{|c|}{ Blacks as $\%$ of all IBM employees in USA, by occupation } \\
\hline Officials/Mgrs & 6.9 & 6.9 & 5.8 & 5.5 \\
\hline Professionals & 6.6 & 7.8 & 7.6 & 6.8 \\
\hline Technicians & 6.7 & 7.8 & 8.7 & 9.4 \\
\hline Marketing & 7.9 & 8.9 & 7.1 & 7.2 \\
\hline Office/Clerical & 21.5 & 26.6 & 22.9 & 21.7 \\
\hline Craft Workers & 9.9 & 14.1 & 7.1 & 8.2 \\
\hline Operatives & 22.5 & 10.3 & 8.2 & 6.3 \\
\hline All U.S. employees & 9.9 & 9.1 & 8.1 & 7.5 \\
\hline \multicolumn{5}{|c|}{ Blacks by occupation \% of all Black IBM employees in USA } \\
\hline Officials/Mgrs & 9.3 & 11.7 & 9.0 & 10.3 \\
\hline Professionals & 29.3 & 34.7 & 40.5 & 37.3 \\
\hline Technicians & 6.7 & 8.8 & 9.3 & 8.9 \\
\hline Marketing & 10.1 & 21.9 & 25.0 & 31.8 \\
\hline Office/Clerical & 15.3 & 15.3 & 13.7 & 9.9 \\
\hline Craft Workers & 1.3 & 2.5 & 0.8 & 0.9 \\
\hline Operatives & 28.0 & 5.2 & 1.7 & 0.9 \\
\hline All Black employees in USA & 100.0 & 100.0 & 100.0 & 100.0 \\
\hline
\end{tabular}

Besides being transformed by globalization, during the 1990s and 2000s, employment relations at IBM were undergoing marketization and rationalization. Coming into the 1990s, IBM, the

${ }^{41}$ In 2009 IBM ceased to make its EEO-1 data available and eventually removed the past data from its website. One of the coauthors (Lazonick), who downloaded these data from the IBM website as they became available, thinks that IBM suppressed the EEO-1 information because it permitted one to calculate the rapidly declining U.S.-based employment at IBM in the 2000s, both in absolute terms and relative to its global labor force. See Lazonick, Sustainable Prosperity, pp. 83-89. 
world's leading computer company, was known as an organization that had lifelong employment, a corporate institution "dating back to the days," as former IBM CEO Thomas Watson Jr. put it in his 1990 autobiography, "when Dad [former CEO Thomas Watson Sr.] had refused to fire people during the Depression." 42 Between 1990 and 1994, however, IBM cut its worldwide employment from 374,000 to 220,000 . In the process, the company rid itself of the institution of lifelong employment. From top to bottom, employment at IBM became marketized as it adopted NEBM. ${ }^{43}$

Blacks did not do well with IBM's transition to NEBM. We know from the Sharpe EEO-1 data in Table IV.9 of Working Paper \#4 that in 1990 IBM employed 20,222 Blacks, with that number declining to 18,677 in $1991 .{ }^{44}$ By then, however, IBM was in the process of slashing over 150,000 jobs net between 1990 and 1994, and by 1996, as Table V.8 shows, Black employment had been reduced to 12,412, a drop of 38.6 percent from 1990. For IBM as a whole, worldwide employment fell by 36.5 percent between 1990 and 1996. Nevertheless, Black representation among IBM's U.S. employees increased from 9.1 percent in 1990 to 9.9 percent in 1996. But thereafter it steadily declined, falling to 7.5 percent in 2008, the last year for which IBM has provided this information.

At the highest executive levels - officials and managers-Blacks occupied 6.9 percent of IBM's U.S. positions in 1996 but only 5.5 percent in 2008. In 2000, in the professionals category, IBM employed 4,838 Blacks in the United States, representing 7.8 percent of all U.S. professionals. But by 2008 that number had declined to 3,347 employees, or 6.8 percent of U.S. professionals. The number of Blacks holding technician jobs at IBM also fell over the period, although Blacks as a proportion of all IBM technicians rose to a high of 9.4 percent in 2008.

Between 1996 and 2008, Blacks made progress in "marketing" (typically called "sales workers" on EEO-1 forms), with the number of Black employees in 2008 at 2.3 times its level in 1996. But the 2008 figure was down by over six percent from its peak in 2000, and with IBM increasing its marketing function overall, the proportion of marketing jobs held by Blacks was actually lower in 2008 (7.2 percent) than it had been in 1996 (7.9 percent).

In 2008, the number of Blacks doing administrative (that is, office and clerical) work in the United States was only 41 percent of the 2,185 Blacks who had done that work in 1998. But it was as operatives that Blacks took the hardest hit, as in the 1990s and 2000s IBM disposed of its hardware manufacturing businesses, shifting to software and services. In 1996, 3,474 Blacks were operatives, making up 28.0 percent of all U.S. Black employment in that year. In 2008, there were only 78 black operatives left at IBM, less than one percent of all of IBM's Black employees in the United States in that year. Some of these operatives may have continued to be employed in U.S. facilities that IBM had sold as the company outsourced manufacturing.

Blacks were not the only group adversely affected by IBM's shift out of manufacturing. In 1996, there had been 1,271 Hispanics and 2,882 Asians employed as operatives in the United States; in 2008, only 36 Hispanics and 73 Asians. Over this period, as the total number of Blacks

\footnotetext{
42 Thomas J. Watson Jr. and Peter Petrie, Father, Son, \& Co.: My Life at IBM and Beyond, Bantam Books, 1990, p. 289.

${ }^{43}$ Lazonick, Sustainable Prosperity, ch. 3.

${ }^{44}$ Lazonick et al., "The Unmaking of a Black Blue-Collar Middle Class"; Rochelle Sharpe, "Losing ground: In latest recession, only blacks suffered net employment loss," Wall Street Journal, September 14, 1993, A1.
} 
employed by IBM in the United States fell by 28 percent, the total number of Hispanics declined by just under one percent. But the total number of Asians employed by IBM increased by 58 percent. While Blacks employed in marketing rose by 129 percent from 1996 to 2008, Asians in marketing increased by 602 percent. Blacks experienced declines of 19 percent, eight percent, and four percent as officials and managers, professionals, and technicians, respectively, while Asians had gains of 142 percent, 55 percent, and seven percent. The result: In 1996 the 9,709 Asians employed by IBM in the United States were 7.7 percent of IBM's total U.S. labor force; in 2008 the company's 5,290 Asian employees in the United States were 12.7 percent of the total.

Alongside, IBM, another major Old Economy company that in the 1990s and 2000s was making the transition to NEBM was Hewlett-Packard. The company had been founded in 1939 in Palo Alto, California, in the heart of the industrial district that in the early 1970s became known as Silicon Valley. Hewlett-Packard published its diversity information in full for 2004-2007. After Hewlett-Packard had been split into HP Inc. and Hewlett Packard Enterprise in 2015, both companies released their EEO-1 submissions for 2016, permitting the comparison of Black employment at HP in the mid-2010s with a decade earlier, as shown in Table V.9.

As separate companies, HP Inc. continues to run Hewlett-Packard's computer and printer businesses while Hewlett Packard Enterprise engages in information-technology services and software. In 2016, HP Inc. had 49,000 employees worldwide, with, as shown in Table V.9, 13,613 people in the United States, while Hewlett Packard Enterprise had worldwide employment of 195,000, with 51,989 in the United States. Combined, the U.S. employment of the two companies was just over 25 percent of worldwide employment, far down from 48 percent 14 years earlier. Table V.9 compares HP's Black employment for 2004, 2007, and 2016, combining the EEO-1 data for HP Inc. and Hewlett Packard Enterprise for the most recent year.

In 1990, with 63 percent of worldwide employees in the United States, HP had employed 2,218 Blacks, representing 3.8 percent of its U.S.-based labor force. ${ }^{45}$ In 2004 , with its global labor force at 151,000, up from about 92,000 in 1990, HP employed 3,380 Blacks, 5.3 percent of its U.S. employees. As can be seen in Table V.9, 58 percent of HP's Black employees were professionals - requiring at least a college education, mostly in a STEM field - with Blacks constituting 4.6 percent of all professionals at HP. As the company's U.S.-based labor force declined by 16 percent from 2004 to 2007, its Black labor force fell by 21 percent. There was only a slight decline in Blacks as a percentage of all professionals, while the proportion of HP Blacks who were employed as professionals increased to almost 65 percent. Blacks as officials and managers, however, experienced a 28 percent decline from 2004 to 2007, with 7.7 percent of all Black employees occupying these management positions in 2007.

By 2016, with the combined U.S. employment of HP Inc. and Hewlett Packard Enterprise about 2.5 percent greater than Hewlett-Packard's in 2004, the companies employed 26 percent more Blacks, including 23 percent more as professionals, than 14 years earlier. In 2016, Blacks were 5.8 percent of all professionals, a substantial increase from 2004-2007, buoyed up by Hewlett Packard Enterprise, which employed 90 percent of the combined companies' Black

\footnotetext{
${ }^{45}$ Rochelle Sharpe, "Unequal opportunity: Losing ground on the employment front," Wall Street Journal, September 14, 1993: A12-A13. HP was one of the companies that in 1998 refused to release its EEO-1 information in response to the San Francisco Chronicle FOIA request. Angwin and Castaneda, "The Digital Divide."
} 
professionals. Yet in 2016 Blacks remained under-represented as programmers and engineers at Hewlett Packard Enterprise. While Blacks' 6.4-percent share of professional jobs was greater than Hispanics' 5.9-percent share, both groups lagged far behind Asians' 15.2 percent and whites' 71.0 percent. So too, at Hewlett Packard Enterprise, Asians were 10.1 percent and whites 80.8 percent of officials and managers, but Blacks and Hispanics only 4.0 percent each. In 2004 at HP, Asians had been 10.6 percent of all U.S. employees and 12.6 percent of all professionals; by 2016 , for the combined companies, these figures had risen to 12.6 percent and 15.4 percent.

Table V.9: Blacks in HP's U.S.-based labor force, 2004, 2007, and 2016

\begin{tabular}{|c|c|c|c|c|c|}
\hline & 2004 & 2007 & \multicolumn{3}{|c|}{2016} \\
\hline & HP & HP & HPINC & HPE & $\begin{array}{c}\text { HPINC + } \\
\text { HPE }\end{array}$ \\
\hline \multicolumn{6}{|c|}{ Total number of HP employees in USA } \\
\hline & 64,038 & 53,519 & 13,613 & 51,989 & 65,602 \\
\hline \multicolumn{6}{|c|}{ HP's U.S. employees as \% of world wide employees } \\
\hline & 42.0 & 31.1 & 28.1 & 24.8 & 25.4 \\
\hline \multicolumn{6}{|c|}{ Number of Black HP employees in USA, by occupation } \\
\hline Officials and managers & 288 & 206 & 45 & 261 & 306 \\
\hline Professionals & 1,955 & 1,732 & 234 & 2,170 & 2,404 \\
\hline Technicians & 422 & 360 & 181 & 450 & 631 \\
\hline Sales workers & 63 & 41 & 41 & 223 & 264 \\
\hline Administrative support & 328 & 181 & 18 & 580 & 598 \\
\hline Craft workers & 2 & 3 & 0 & 0 & 0 \\
\hline Operatives & 129 & 30 & 0 & 15 & 15 \\
\hline Laborers & 193 & 116 & 0 & 35 & 35 \\
\hline All Black employees in USA & 3,380 & 2,669 & 519 & 3,734 & 4,253 \\
\hline \multicolumn{6}{|c|}{ Blacks as \% of all HP employees in USA, by occupation } \\
\hline Officials and managers & 3.5 & 3.0 & 2.1 & 4.0 & 3.5 \\
\hline Professionals & 4.6 & 4.5 & 3.2 & 6.4 & 5.8 \\
\hline Technicians & 7.4 & 8.5 & 9.0 & 12.2 & 11.1 \\
\hline Sales workers & 4.3 & 5.4 & 2.6 & 5.0 & 4.4 \\
\hline Administrative support & 9.5 & 8.9 & 3.3 & 19.9 & 17.2 \\
\hline Craft workers & 3.1 & 16.7 & na & na & na \\
\hline Operatives & 20.3 & 12.6 & 0.0 & 22.1 & 20.3 \\
\hline Laborers & 10.1 & 10.4 & 0.0 & 19.1 & 18.5 \\
\hline All U.S. employees & 5.3 & 5.0 & 3.8 & 7.2 & 6.5 \\
\hline \multicolumn{6}{|c|}{ Blacks by occupation as \% of all Black HP employees in USA } \\
\hline Officials and managers & 8.5 & 7.7 & 8.7 & 7.0 & 7.2 \\
\hline Professionals & 57.8 & 64.9 & 45.1 & 58.1 & 56.5 \\
\hline Technicians & 12.5 & 13.5 & 34.9 & 12.1 & 14.8 \\
\hline Sales workers & 1.9 & 1.5 & 7.9 & 6.0 & 6.2 \\
\hline Administrative support & 9.7 & 6.8 & 3.5 & 15.5 & 14.1 \\
\hline Craft workers & 0.1 & 0.1 & 0.0 & 0.0 & 0.0 \\
\hline Operatives & 3.8 & 1.1 & 0.0 & 0.4 & 0.4 \\
\hline Laborers & 5.7 & 4.3 & 0.0 & 0.9 & 0.8 \\
\hline All Black employees in USA & 100.0 & 100.0 & 100.0 & 100.0 & 100.0 \\
\hline
\end{tabular}

Note: Data for senior and mid-level officials and managers have been combined.

Sources: HP website, downloaded by William Lazonick prior to 2009 (data no longer visible on the HP website), HP FY07 Global Citizenship Report (p. 34); HP Inc. and Hewlett Packard Enterprise EEO-1 submissions, 2016. 
Another tech company of great importance for well-paid professional employment for which we possess an unusual amount of EEO-1 data over time is Intel, founded in Mountain View, California in 1968. From 1991 to 2020, Intel was the world's leading chip company by revenues, before it was surpassed in 2021 by Samsung Electronics. ${ }^{46}$ Although headquartered in Silicon Valley, since the mid-1980s the largest share of Intel's U.S. employees has worked in Washington County, Oregon, where, in 1974, Intel had launched its first microprocessor fabrication facility. In late 2021, about 21,000 of Intel's 121,000 global employees were based in Oregon. ${ }^{47}$

EEO-1 data obtained for the 1998 Angwin-Castaneda study show that Intel employed 30,003 people in the United Sates of a worldwide labor force of 64,500, as shown in Table V.10. At all occupational levels, Blacks were under-represented among Intel's U.S. employees.

Table V.10: Intel's U.S.-based employment, by occupational category and race/ethnicity, 1998

\begin{tabular}{|l|r|r|r|c|}
\hline & $\begin{array}{c}\text { No. of } \\
\text { employees }\end{array}$ & \% white & \% Asian & \% Black \\
\hline Officials/Managers & 2,862 & 84 & 8 & 2 \\
\hline “Professionals" (see note) & 22,519 & 70 & 18 & 3 \\
\hline Factory/Support Staff & 4,622 & 71 & 8 & 4 \\
\hline All U.S. employees & 30,003 & 71 & 16 & 3 \\
\hline
\end{tabular}

Note: According to Angwin and Castaneda: "Professionals include positions that require four-year degrees, and sales and technical jobs that require a two-year degree. Factory/support staff includes clerical and service workers as well as laborers, operators, and craftworkers."

Source: Angwin and Castaneda, "The Digital Divide."

Table V.11 compares EEO-1 data for Intel for 2005, 2012, 2016, and 2019. Like IBM and HP, Intel published some EEO-1 data in the 2000s. We also found Intel's EEO-1 submission for 2012 online. Apparently in response to the Rainbow PUSH Coalition initiative, Intel released its EEO1 employment data for 2014, 2015, and 2016. The company did not publish its subsequent EEO1 employment reports. In 2019, however, as part of an "Early Resolution Agreement" with the U.S. Department of Labor, Intel agreed to allocate $\$ 5$ million in pay adjustments "to resolve allegations of systemic pay discrimination against female, African American and Hispanic American employees at its facilities in Arizona, California and Oregon."48 As part of this agreement, Intel agreed to publish pay data for 2017-2019, from which we can derive the employment data (shown for 2019 in Table V.11) that Intel submitted to the EEOC for those years. $^{49}$

\footnotetext{
${ }^{46}$ Ryosuke Eguchi, "Samsung overtook Intel as top chip seller in 2021,” Nikkei Asia, January 20, 2022. See also William Lazonick and Matt Hopkins, "Why the CHIPS Are Down: Stock Buybacks and Subsidies in the U.S. Semiconductor Industry," Institute for New Economic Thinking Working Paper No. 165, November 1, 2021, at https:/www.ineteconomics.org/research/research-papers/why-the-chips-are-down-stock-buybacks-and-subsidies-in-the-u-ssemiconductor-industry.

${ }^{47}$ Mike Rogoway, "Intel's CEO comes to Oregon, stumping for billions to aid his industry and his company," The Oregonian, December 5, 2021, at https:/www.oregonlive.com/silicon-forest/2021/12/intels-ceo-comes-to-oregon-stumpingfor-billions-to-aid-his-industry-and-his-company.html.

48 U.S. Department of Labor, "U.S. Department of Labor reaches \$5 million settlement with Intel Corp. to resolve pay discrimination allegations," Office of Federal Contract Compliance Programs News Release, October 15, 2019, at https://www.dol.gov/newsroom/releases/ofccp/ofccp20191015.

49 Intel, "Intel 2017, 2018, and 2019 EEO-1 Pay Disclosure," Intel Corporation, n.d., at https://www.intel.com/content/www/us/en/diversity/2017-2019-eeo-1-pay-disclosure-report.html.
} 
Intel's U.S. employment of 54,135 in 2016 was a net increase of only 174 employees from 2005, and in 2019 it was five percent less than in 2005. Blacks in U.S. employment at Intel rose from 1,849 in 2005 to 2,108 in 2016 before declining to 2,027 in 2019, representing 4.0 percent of U.S. employees. The proportion of Intel's Black employees who were professionals increased from 41.3 percent in 2005 to 59.2 percent in 2016 and then dipped to 57.9 percent in 2019 . Along with a net increase of 67 Black officials and managers in 2019 compared with 2005 (a 45percent gain), Black professionals rose by 410 (54 percent). Blacks had been only 2.5 percent of Intel's U.S. professionals in 2005 and were still only 3.4 percent in 2016 and 2019. At 7.2 percent, Blacks represented a somewhat higher proportion of technicians than they been in 2005 , 2012, and 2016, but Blacks held 264 fewer technician positions in 2019 compared with 2005.

Table V.11: Blacks in Intel's U.S.-based labor force, 2005, 2012, 2016, and 2019

\begin{tabular}{|c|c|c|c|c|}
\hline & 2005 & 2012 & 2016 & 2019 \\
\hline \multicolumn{5}{|c|}{ Total number of Intel employees in USA } \\
\hline & 53,961 & 52,797 & 54,135 & 51,267 \\
\hline \multicolumn{5}{|c|}{ Intel's U.S. employees \% of world wide employees } \\
\hline & 55.6 & 49.7 & 51.9 & 46.3 \\
\hline \multicolumn{5}{|c|}{ Number of Black intel employees in USA, by occupation } \\
\hline Officials and managers & 150 & 162 & 195 & 217 \\
\hline Professionals & 764 & 994 & 1,247 & 1,174 \\
\hline Technicians & 836 & 648 & 536 & 572 \\
\hline Sales workers & 3 & 55 & 60 & 22 \\
\hline Administrative support & 72 & 65 & 61 & 29 \\
\hline Craft workers & 22 & 21 & 8 & 13 \\
\hline Operatives & 2 & 1 & 0 & 0 \\
\hline Service workers & 0 & 1 & 1 & 0 \\
\hline All Black employees in USA & 1,849 & 1,946 & 2,108 & 2,027 \\
\hline \multicolumn{5}{|c|}{ Blacks as \% of all Intel employees in USA, by occupation } \\
\hline Officials and managers & 2.0 & 2.3 & 2.9 & 3.2 \\
\hline Professionals & 2.5 & 3.1 & 3.4 & 3.4 \\
\hline Technicians & 6.4 & 6.5 & 6.3 & 7.2 \\
\hline Sales workers & 2.1 & 4.1 & 4.5 & 3.2 \\
\hline Administrative support & 3.9 & 5.2 & 6.3 & 4.0 \\
\hline Craft workers & 3.0 & 3.3 & 2.1 & 3.2 \\
\hline Operatives & 4.3 & 4.8 & 0.0 & 0.0 \\
\hline Laborers & 0.0 & 50.0 & 100.0 & 0.0 \\
\hline All U.S. employees & 3.4 & 3.7 & 3.9 & 4.0 \\
\hline \multicolumn{5}{|c|}{ Blacks by occupation \% of all Black Intel employees in USA } \\
\hline Officials and managers & 8.1 & 8.3 & 9.3 & 10.7 \\
\hline Professionals & 41.3 & 51.1 & 59.2 & 57.9 \\
\hline Technicians & 45.2 & 33.3 & 25.4 & 28.2 \\
\hline Sales workers & 0.2 & 2.8 & 2.8 & 1.1 \\
\hline Administrative support & 3.9 & 3.3 & 2.9 & 1.4 \\
\hline Craft workers & 1.2 & 1.1 & 0.4 & 0.6 \\
\hline Operatives & 0.1 & 0.1 & 0.0 & 0.0 \\
\hline Laborers & 0.0 & 0.1 & 0.0 & 0.0 \\
\hline All Black employees in USA & 100.0 & 100.0 & 100.0 & 100.0 \\
\hline
\end{tabular}

Note: Data for senior and mid-level officials and managers have been combined. Sources: Intel website for 2005; EEO-1 employment reports for 2012 and 2016; 2019 from Intel 2017, 2018 and 2019 EEO-1 pay disclosures. 
Almost all of Intel's U.S. employees were concentrated in the top four occupational categories with, in 2019, 13.2 percent officials and managers, 67.7 percent professionals, and 15.6 percent technicians, but only just over 3.5 percent in all the lower categories. This "knowledge worker" occupational structure has become typical of tech companies, with traditional manufacturing employment almost entirely absent in the United States. As an integrated device manufacturer, Intel both designs and fabricates chips, whereas U.S. semiconductor companies such as Advanced Micro Devices (AMD), Nvidia, and Qualcomm are "fabless." Yet even a semiconductor manufacturer such as Intel employs virtually no people in the operative and laborers categories associated with "Old Economy" blue-collar jobs in mass-production industries such as automobiles, electrical machinery, consumer electronics, and steel. And at Intel, as we have seen, Blacks are poorly represented in the officials/managers, professionals, and technicians categories that constitute the vast majority of Intel employees.

For all racial and ethnic groups - Blacks, Hispanics, Asians, and whites-women have had much lower representation than men among Intel's U.S. employees. The male/female ratio was lowest for Asians (2.0:1 in 2019) and highest for whites (3.5:1). Both Asian men and women were highly concentrated in the professionals category, which accounted for 81.1 percent of all Asian men and 85.1 percent of all Asian women in 2019. Although there are about ten times as many whites as Asians in the U.S. population, there were more Asian women $(6,368)$ than white women $(5,349)$ employed by Intel in the United States in 2019, including, as professionals, 5,416 Asian females and 3,248 white females. In that year, Intel employed 842 Black men and 332 Black women as professionals, while 488 Black men and 84 Black women were technicians.

On March 31, 2021, California began requiring any company with at least 100 employees nationwide and at least one employee based in California to include pay data in their EEO-1 submissions. ${ }^{50}$ This state legislation resurrected an Obama administration EEOC initiative for collecting pay data as "Component 2" on EEO-1 forms that had been cancelled by the Trump administration. ${ }^{51}$ To our knowledge the only EEO-1 company pay data that has been made public is the Intel document for 2017, 2018, and 2019 as part of its settlement with the U.S. Department of Labor for allegations of pay discrimination against the company. ${ }^{52}$

Table V.12 presents the percentage distributions within race, ethnicity, and gender groups across 12 pay categories of Intel's U.S. professionals and technicians. For the total and each race, ethnicity, or gender group, the percentages in the columns for the 12 professionals or technicians pay levels add to 100.0 percent. Evidence of possible pay discrimination exists against a group that is over-represented at the lower pay levels and under-represented at the higher pay levels. Even then, it is possible that such a distributional pattern among a group is because its members have tended to be more recent hires with lower pay levels because of less work experience. In that case, higher concentration of a group's members at lower pay levels may be the result of past discrimination in hiring rather than current discrimination in pay. Note also that almost all U.S. professionals and technicians at Intel receive an unspecified portion of their compensation

\footnotetext{
${ }^{50}$ California Department of Fair Housing and Employment, "California Pay Data Reporting: Frequently Asked Questions," ca.gov, February 3, 2022., at https://www.dfeh.ca.gov/paydatareporting/faqs/. As discussed below, Intel has released it EEO-1 pay data for 2017-2019: Intel, "Intel 2017, 2018, and 2019 EEO-1 Pay Disclosure."

${ }^{51}$ U.S. Equal Opportunity Employment Commission, "EEOC announces analysis of EEO-1 Component 2 Pay Data Collection."

52 Intel, "Intel 2017, 2018 and 2019 EEO-1 Pay Disclosure."
} 
in the form of stock awards, the realized gains from which can vary among employees depending on the timing of the award grants and the number of corporate shares in an award. ${ }^{53}$

Table V.12: Percentage pay-level distributions of professionals and technicians at Intel within race, ethnicity, and gender groups, 2019

\begin{tabular}{|c|c|c|c|c|c|c|c|c|c|}
\hline \multirow{2}{*}{$\begin{array}{l}\text { Pay } \\
\text { level }\end{array}$} & \multirow{2}{*}{ Professionals } & \multirow{2}{*}{$\begin{array}{c}\text { No. of } \\
\text { employees }\end{array}$} & \multicolumn{7}{|c|}{$\%$ of gender, race, or ethnicity group, by pay level } \\
\hline & & & Total & Men & Women & White & Black & Asian & Hispanic \\
\hline 1 & $\$ 19,239$ and under & 185 & 0.5 & 0.4 & 0.8 & 0.4 & 1.4 & 0.6 & 0.5 \\
\hline 2 & $\$ 19,240-\$ 24,439$ & 98 & 0.3 & 0.2 & 0.4 & 0.2 & 0.3 & 0.4 & 0.3 \\
\hline 3 & $\$ 24,440-\$ 30,679$ & 155 & 0.4 & 0.4 & 0.6 & 0.4 & 0.2 & 0.5 & 0.4 \\
\hline 4 & $\$ 30,680-\$ 38,999$ & 254 & 0.7 & 0.6 & 1.0 & 0.6 & 1.5 & 0.7 & 1.0 \\
\hline 5 & $\$ 39,000-\$ 49,919$ & 462 & 1.3 & 1.1 & 1.9 & 1.1 & 2.4 & 1.3 & 2.2 \\
\hline 6 & $\$ 49,920-\$ 62,919$ & 682 & 2.0 & 1.5 & 3.1 & 1.7 & 3.2 & 2.0 & 2.4 \\
\hline 7 & $\$ 62,920-\$ 80,079$ & 1,751 & 5.0 & 4.0 & 7.6 & 5.2 & 7.4 & 4.2 & 7.6 \\
\hline 8 & $\$ 80,080-\$ 101,919$ & 5,252 & 15.1 & 13.2 & 20.1 & 12.6 & 19.0 & 16.5 & 16.9 \\
\hline 9 & $\$ 101,920-\$ 128,959$ & 7,697 & 22.2 & 20.9 & 25.3 & 19.2 & 26.5 & 24.3 & 23.6 \\
\hline 10 & $\$ 128,960-\$ 163,799$ & 7,927 & 22.8 & 23.5 & 21.3 & 22.9 & 21.7 & 22.8 & 24.7 \\
\hline 11 & $\$ 163,800-\$ 207,999$ & 5,551 & 16.0 & 17.9 & 11.1 & 17.8 & 10.0 & 15.5 & 12.6 \\
\hline 12 & $\$ 208,000$ and over & 4,685 & 13.5 & 16.2 & 6.7 & 17.9 & 6.5 & 11.2 & 7.6 \\
\hline \multirow{2}{*}{$\begin{array}{l}\text { Pay } \\
\text { level } \\
\end{array}$} & \multirow{2}{*}{ Technicians } & \multirow{2}{*}{$\begin{array}{c}\text { No. of } \\
\text { employees }\end{array}$} & \multicolumn{7}{|c|}{$\%$ of gender, race, or ethnicity group, by pay level } \\
\hline & & & Total & Men & Women & White & Black & Asian & Hispanic \\
\hline 1 & $\$ 19,239$ and under & 123 & 3.5 & 2.5 & 8.5 & 2.7 & 9.3 & 4.4 & 2.7 \\
\hline 2 & $\$ 19,240-\$ 24,439$ & 51 & 1.4 & 1.1 & 2.9 & 1.1 & 3.8 & 1.2 & 1.2 \\
\hline 3 & $\$ 24,440-\$ 30,679$ & 63 & 1.6 & 1.5 & 2.0 & 1.4 & 3.0 & 1.9 & 1.3 \\
\hline 4 & $\$ 30,680-\$ 38,999$ & 65 & 2.0 & 1.8 & 3.1 & 1.4 & 4.0 & 2.7 & 2.1 \\
\hline 5 & $\$ 39,000-\$ 49,919$ & 155 & 3.9 & 3.2 & 7.5 & 3.4 & 5.1 & 4.1 & 4.6 \\
\hline 6 & $\$ 49,920-\$ 62,919$ & 473 & 10.9 & 10.0 & 15.3 & 10.4 & 7.0 & 13.9 & 10.3 \\
\hline 7 & $\$ 62,920-\$ 80,079$ & 1,288 & 27.9 & 28.1 & 26.7 & 28.4 & 24.8 & 27.1 & 26.8 \\
\hline 8 & $\$ 80,080-\$ 101,919$ & 1,577 & 33.3 & 35.4 & 22.8 & 34.8 & 31.6 & 27.9 & 35.6 \\
\hline 9 & $\$ 101,920-\$ 128,959$ & 606 & 12.5 & 13.8 & 6.2 & 13.4 & 10.5 & 10.7 & 13.4 \\
\hline 10 & $\$ 128,960-\$ 163,799$ & 107 & 2.4 & 2.1 & 3.9 & 2.4 & 0.7 & 5.0 & 1.7 \\
\hline 11 & $\$ 163,800-\$ 207,999$ & 19 & 0.5 & 0.4 & 0.9 & 0.4 & 0.2 & 1.0 & 0.2 \\
\hline 12 & $\$ 208,000$ and over & 4 & 0.1 & 0.1 & 0.1 & 0.1 & 0.0 & 0.0 & 0.1 \\
\hline
\end{tabular}

Source: Intel, "Intel 2017, 2018 and 2019 EEO-1 Pay Disclosure."

For professionals, the pattern of percentage pay-level distributions displayed in Table V.12 is very similar for Blacks and women, suggesting possible pay and/or employment discrimination against both groups. Relative to the distributions of all employees across the 12 pay grades, Blacks and women are over-represented in pay-levels 1 through 9, slightly under-represented in pay-level 10, and significantly under-represented in pay-levels 11 and 12. Among technicians, Blacks are over-represented at pay-levels 1 through 5 and under-represented at pay-levels 6 through 12. As both professionals and technicians, Hispanics fare significantly better than Blacks.

Although Intel states that "Technicians [as an EEO-1 category] coordinate most closely to hourly workers," 54 the company does not employ a traditional blue-collar labor force in the United

\footnotetext{
${ }^{53}$ Matt Hopkins and William Lazonick, "The Mismeasure of Mammon, Uses and Abuses of Executive Pay Data," Institute for New Economic Thinking Working Paper No. 49, August 29, 2016, at https://www.ineteconomics.org/research/researchpapers/the-mismeasure-of-mammon-uses-and-abuses-of-executive-pay-data. The pay data that Intel reports in "Intel 2017, 2018 and 2019 EEO-1 Pay Disclosure," were "collected from employees' W2 box 1 earnings," which means that these data include realized gains from stock-based pay.

54 Intel "Intel 2017, 2018 and 2019 EEO-1 Pay Disclosure."
} 
States. Nor does Intel employ low-paid service workers. Other leading tech companies, however, have business models that include the mass employment of relatively low-paid workers in the United States. As a prime example, Apple employs tens of thousands of workers in its U.S. stores (see Table V. 13). Apple's U.S.-based retail employees increased from 807 in 2001, when it opened its first store, to an estimated 27,500 in 2014 (the last year in which Apple published the data that permit us to estimate the number of employees in its U.S. stores). Under the EEO-1 classifications, most of these employees were sales workers but some were technicians, and a smaller number were managers.

Table V.13: Apple retail stores and retail employees, U.S.based and international, 2001-2014

\begin{tabular}{|l|r|r|r|r|r|}
\hline & $\begin{array}{c}\text { U.s. retail } \\
\text { stores }\end{array}$ & $\begin{array}{c}\text { Inter- } \\
\text { national } \\
\text { retail stores }\end{array}$ & $\begin{array}{c}\text { Retail } \\
\text { employees, } \\
\text { worldwide }\end{array}$ & $\begin{array}{c}\text { Retail } \\
\text { employees } \\
\text { per store }\end{array}$ & $\begin{array}{c}\text { Estimated } \\
\text { U.S. retail } \\
\text { employees }\end{array}$ \\
\hline $\mathbf{2 0 0 1}$ & 8 & 0 & & & \\
\hline $\mathbf{2 0 0 2}$ & 40 & 0 & 807 & 20 & 807 \\
\hline $\mathbf{2 0 0 3}$ & 65 & 0 & 1,300 & 20 & 1,300 \\
\hline $\mathbf{2 0 0 4}$ & 84 & 2 & 2,100 & 24 & 2,051 \\
\hline $\mathbf{2 0 0 5}$ & 116 & 8 & 3,673 & 30 & 3,436 \\
\hline $\mathbf{2 0 0 6}$ & 147 & 18 & 5,787 & 35 & 5,156 \\
\hline $\mathbf{2 0 0 7}$ & 174 & 23 & 7,900 & 40 & 6,978 \\
\hline $\mathbf{2 0 0 8}$ & 205 & 42 & 15,900 & 64 & 13,196 \\
\hline $\mathbf{2 0 0 9}$ & 217 & 56 & 16,500 & 60 & 13,115 \\
\hline $\mathbf{2 0 1 0}$ & 233 & 84 & 26,500 & 84 & 19,478 \\
\hline $\mathbf{2 0 1 1}$ & 245 & 112 & 36,000 & 101 & 24,706 \\
\hline $\mathbf{2 0 1 2}$ & 250 & 140 & 42,400 & 109 & 27,179 \\
\hline $\mathbf{2 0 1 3}$ & 254 & 162 & 42,800 & 103 & 26,133 \\
\hline $\mathbf{2 0 1 4}$ & 259 & 176 & 46,200 & 106 & 27,508 \\
\hline
\end{tabular}

Note: U.S. retail employees have been estimated by assuming that U.S stores have the same number of employees on average as all stores, U.S. and international Source: Apple 10-K filings with the U.S. Securities and Exchange Commission, 2001-2014.

Most of these retail jobs are low paid (defined as income less than about $\$ 33,500$ per year in 2018). ${ }^{55}$ According to Glassdoor, in 2018 the base wage of Apple retail workers was $\$ 15$ per hour, rising to $\$ 21$ per hour for a "MacGenius" employee. Technical specialists at Apple received a base wage of $\$ 15$ per hour, or $\$ 31,200$ per year. By contrast, an Apple software engineer had a base annual salary of about $\$ 122,000 .^{56}$

Apple has released its EEO-1 data for 2014, 2015, 2016, 2017, 2018, and 2020. Previously, the company provided no public information on its employment diversity. We know from its 2014 EEO-1 submission that in 2013 Apple had 54,644 employees in the United States, of whom 2,727 (4.2 percent) were Black males and 1,523 (2.8 percent) were Black females. Table V.14 shows Apple's total U.S. employment by occupational category for 2014. 2017, 2018, and 2020.

\footnotetext{
${ }^{55}$ For a thorough discussion of the definition of low-paid work, see Heather Boushey, Shawn Fremstad, Rachel Gragg, and Margy Waller, "Understanding Low-Wage Work in the United States," March 2007, at https://core.ac.uk/download/pdf/6967463.pdf ("we define a low-wage job as one that pays less than two-thirds of the median wage for men.” p. 4). In the first quarter of 2018, the median weekly earnings for men in the United States was $\$ 965$ (https://www.bls.gov/opub/ted/2018/median-weekly-earnings-783-for-women-965-for-men-in-first-quarter-2018.htm), or $\$ 50,180$ per year. By the "two-thirds" definition given by Boushey et al., low-paid work in the United States is a job that pays less than $\$ 33,453$.

${ }^{56}$ Glassdoor, “Apple salaries,” at https://www.glassdoor.com/Salary/Apple-Salaries-E1138.htm.
} 
Apple expanded its U.S. employment by 40 percent between 2014 and 2017 and another 14 percent between 2017 and 2020. Most pronounced was the increase in the professionals employed in the United States, with the number in 2020 two-and-a-half times that in 2014. From the data available, sales workers in the U.S. (mainly in Apple stores) reached a peak of 26,102 employees in 2017, with 25,625 in 2018.

Table V.14: Apple's U.S. employees by EEO-1 occupational categories, 2014, 2017, 2018, and 2020

\begin{tabular}{|c|c|c|c|c|c|c|c|c|}
\hline & \multicolumn{4}{|c|}{ Number of U.S. employees } & \multicolumn{4}{|c|}{$\%$ of all employees } \\
\hline & 2014 & 2017 & 2018 & 2020 & 2014 & 2017 & 2018 & 2020 \\
\hline Executive/SR Officials \& Managers & 83 & 115 & 123 & 126 & 0.1 & 0.1 & 0.1 & 0.1 \\
\hline First/Mid Officials \& Managers & 5,942 & 9,134 & 9,878 & 11,757 & 9.9 & 10.9 & 11.1 & 12.3 \\
\hline Professionals & 15,494 & 27,010 & 30,745 & 38,657 & 25.9 & 32.2 & 34.5 & 40.5 \\
\hline Technicians & 13,380 & 14,989 & 7,350 & 7,345 & 22.3 & 17.9 & 8.3 & 7.7 \\
\hline Sales Workers & 19,210 & 26,102 & 25,625 & 23,449 & 32.1 & 31.2 & 28.8 & 24.6 \\
\hline Administrative Support & 5,429 & 5,754 & 14,340 & 13,141 & 9.1 & 6.9 & 16.1 & 13.8 \\
\hline Craft Workers & 94 & 98 & 115 & 109 & 0.2 & 0.1 & 0.1 & 0.1 \\
\hline Operatives & 0 & 0 & 0 & 0 & 0.0 & 0.0 & 0.0 & 0.0 \\
\hline Laborers \& Helpers & 0 & 0 & 0 & 0 & 0.0 & 0.0 & 0.0 & 0.0 \\
\hline Service Workers & 237 & 557 & 896 & 862 & 0.4 & 0.7 & 1.0 & 0.9 \\
\hline All U.S. employees & 59,869 & 83,759 & 89,072 & 95,446 & 100.0 & 100.0 & 100.0 & 100.0 \\
\hline
\end{tabular}

Source: Apple EEO-1 reports to the U.S. Equal Opportunity Employment Commission.

As shown in Table V.14, with the expansion of the number of Apple stores, by 201432.1 percent of Apple's U.S. employees were sales workers, surpassing the 25.9 percent who were professionals and 22.3 percent who were technicians. Black employment benefited from Apple's rapid expansion in retail, occupying a relatively high 16.6 percent of the company's sales-worker positions in 2020 (see Table V.15).

By 2020, just over 40 percent of all U.S, employees were in the professionals occupation, up from 26 percent in 2014. Note the dramatic decline in the number of technicians in the United States in 2018, as the numbers employed in this occupational category were more than halved, from 14,989 in 2017 to 7,350 in 2018, a reduction of 7,639. At the same time, however, Apple dramatically increased its administrative-support employees by 8,586. It is clear that, for some reason, Apple decided to reclassify a large proportion of its technicians in 2017 as administrative support employees in 2018. When we add together the two occupational categories and calculate the representations of various subgroups such as Black male, Black female, etc. as proportions of Apple's total U.S. employment in each year, the percentages remain close to the same in both 2017 and 2018.

Notwithstanding this reclassification, in both 2017 and 2018 Blacks are 9.2 percent of all Apple employees in the United States, up from 8.0 percent in 2014 (see Table V.15). In 2020, however, Blacks represent only 8.5 percent of Apple's U.S, employees, even as Apple's total U.S.-based employment rose substantially from 85,072 in 2018 to 95,446 in 2020. This result appears to be in part related to the SARS-CoV-2 pandemic. The payroll period in which the 2020 data was collected was 12/16/20-12/31/20, when the United States was still largely in lockdown, with Apple stores and offices closed. In 2018, 80.7 of Blacks were either sales workers or administrative support; in 2020, 75.0 percent. From 2018 to 2020 Blacks lost 477 in these two 
categories combined, while they only gained 452 jobs in officials \& managers, professionals, and technicians combined.

Table V.15: Blacks in Apple's U.S.-based labor force, 2014, 2017, 2018, and 2020

\begin{tabular}{|c|c|c|c|c|}
\hline & 2014 & 2017 & 2018 & 2020 \\
\hline \multicolumn{5}{|c|}{ Total number of Apple employees in USA } \\
\hline & 59,869 & 83,759 & 89,072 & 95,446 \\
\hline \multicolumn{5}{|c|}{ Apple's U.S. employees as \% of worldwide employees } \\
\hline & 64.7 & 68.1 & 67.5 & 64.9 \\
\hline \multicolumn{5}{|c|}{ Number of Black Apple employees in USA } \\
\hline Officials \& Managers & 203 & 283 & 285 & 340 \\
\hline Professionals & 256 & 486 & 553 & 849 \\
\hline Technicians & 1,517 & 2,331 & 694 & 795 \\
\hline Sales Workers & 2,274 & 3,948 & 4,106 & 3,881 \\
\hline Administrative Support & 540 & 635 & 2,472 & 2,225 \\
\hline Craft Workers & 2 & 2 & 3 & 2 \\
\hline Operatives & 0 & 0 & 0 & 0 \\
\hline Laborers \& Helpers & 0 & 0 & 0 & 0 \\
\hline Service Workers & 17 & 25 & 38 & 44 \\
\hline All Black employees in USA & 4,809 & 7,710 & 8,151 & 8,136 \\
\hline \multicolumn{5}{|c|}{ Blacks as $\%$ of all Apple employees in USA, by occupation } \\
\hline Officials \& Managers & 3.4 & 3.1 & 2.8 & 2.9 \\
\hline Professionals & 1.7 & 1.8 & 1.8 & 2.2 \\
\hline Technicians & 11.3 & 15.6 & 9.4 & 10.8 \\
\hline Sales Workers & 11.8 & 15.1 & 16.0 & 16.6 \\
\hline Administrative Support & 9.9 & 11.0 & 17.2 & 16.9 \\
\hline Craft Workers & 2.1 & 2.0 & 2.6 & 1.8 \\
\hline Operatives & na & na & na & na \\
\hline Laborers \& Helpers & na & na & na & na \\
\hline Service Workers & 7.2 & 4.5 & 4.2 & 5.1 \\
\hline All U.S. employees & 8.0 & 9.2 & 9.2 & 8.5 \\
\hline \multicolumn{5}{|c|}{ Blacks by occupation as \% of all Black Apple employees in USA } \\
\hline Officials \& Managers & 4.2 & 3.7 & 3.5 & 4.2 \\
\hline Professionals & 5.3 & 6.3 & 6.8 & 10.4 \\
\hline Technicians & 31.5 & 30.2 & 8.5 & 9.8 \\
\hline Sales Workers & 47.3 & 51.2 & 50.4 & 47.7 \\
\hline Administrative Support & 11.2 & 8.2 & 30.3 & 27.3 \\
\hline Craft Workers & 0.0 & 0.0 & 0.0 & 0.0 \\
\hline Operatives & 0.0 & 0.0 & 0.0 & 0.0 \\
\hline Laborers \& Helpers & 0.0 & 0.0 & 0.0 & 0.0 \\
\hline Service Workers & 0.4 & 0.3 & 0.5 & 0.5 \\
\hline All Black employees in USA & 100.0 & 100.0 & 100.0 & 100.0 \\
\hline
\end{tabular}

Note: Data for senior and mid-level officials and managers have been combined.

Source: Apple EEO-1 reports to the U.S. Equal Opportunity Employment Commission.

As a result, total Black U.S, employment at Apple fell from 8,151 to 8,136 employees from 2018 to 2020 , even as there was a net addition of 6,730 U.S, jobs at Apple. Of 1,885 officials \& managers that Apple added, Blacks got a net increase of only 55. Of 7,912 professionals that Apple added, Blacks got a net increase of only 296. Yet Black shares of these occupations were so meager in 2018 that even these small number of additional jobs caused Blacks proportional shares of both these categories to rise slightly. Blacks achieved their largest proportional increase 
in 2020 compared with 2018 among technicians, rising from 9.4 percent to 10.8 percent of this occupational category, with a net addition of 101 Black technicians even as Apple chipped off five of these positions overall in the United States.

Table V.16 compares the racial, ethnic, and gender distribution of Apple's U.S. jobs by occupation in 2020. As at Intel, there was vast over-representation of Asian males among professionals. Asian females are also over-represented, but with only 38 percent of the number of professional jobs as Asian men. Nevertheless, as was the case at Intel, the number of Asian women outstripped the number of white women. Hispanics, both men and women, did markedly better than Black males and Black females respectively.

Table V.16: Racial, ethnic, and gender composition of Apple's U.S.-based labor force, 2020

\begin{tabular}{|c|c|c|c|c|c|c|c|c|}
\hline 2020 & $\begin{array}{l}\text { Black } \\
\text { males }\end{array}$ & $\begin{array}{c}\text { Black } \\
\text { females }\end{array}$ & $\begin{array}{c}\text { Hispanic } \\
\text { males }\end{array}$ & $\begin{array}{c}\text { Hispanic } \\
\text { females }\end{array}$ & $\begin{array}{l}\text { Asian } \\
\text { males }\end{array}$ & $\begin{array}{c}\text { Asian } \\
\text { females }\end{array}$ & $\begin{array}{l}\text { White } \\
\text { males }\end{array}$ & $\begin{array}{l}\text { White } \\
\text { females }\end{array}$ \\
\hline \multicolumn{9}{|l|}{ Number of Apple employees in USA } \\
\hline Executive/SR Officials \& Managers & 0 & 1 & 1 & 0 & 16 & 6 & 82 & 19 \\
\hline First/Mid Officials \& Managers & 189 & 150 & 567 & 257 & 2,582 & 957 & 4,992 & 1,844 \\
\hline Professionals & 544 & 305 & 1,448 & 715 & 12,876 & 5,238 & 12,525 & 4,006 \\
\hline Technicians & 580 & 215 & 993 & 450 & 510 & 264 & 3,163 & 875 \\
\hline Sales Workers & 2,390 & 1,491 & 3,499 & 2,137 & 1,304 & 718 & 7,111 & 3,422 \\
\hline Administrative Support & 921 & 1,304 & 1,407 & 1,194 & 531 & 638 & 3,753 & 2,725 \\
\hline Craft Workers & 2 & 0 & 22 & 2 & 19 & 1 & 60 & 1 \\
\hline Operatives & 0 & 0 & 0 & 0 & 0 & 0 & 0 & 0 \\
\hline Laborers \& Helpers & 0 & 0 & 0 & 0 & 0 & 0 & 0 & 0 \\
\hline Service Workers & 25 & 19 & 225 & 309 & 92 & 38 & 80 & 35 \\
\hline All U.S. employees & 4,651 & 3,485 & 8,162 & 5,064 & 17,930 & 7,860 & 31,766 & 12,927 \\
\hline \multicolumn{9}{|c|}{$\%$ of all Apple employees in USA, by occupation } \\
\hline Executive/SR Officials \& Managers & 0.0 & 0.8 & 0.8 & 0.0 & 12.7 & 4.8 & 65.1 & 15.1 \\
\hline First/Mid Officials \& Managers & 1.6 & 1.3 & 4.8 & 2.2 & 22.0 & 8.1 & 42.5 & 15.7 \\
\hline Professionals & 1.4 & 0.8 & 3.7 & 1.8 & 33.3 & 13.5 & 32.4 & 10.4 \\
\hline Technicians & 7.9 & 2.9 & 13.5 & 6.1 & 6.9 & 3.6 & 43.1 & 11.9 \\
\hline Sales Workers & 10.2 & 6.4 & 14.9 & 9.1 & 5.6 & 3.1 & 30.3 & 14.6 \\
\hline Administrative Support & 7.0 & 9.9 & 10.7 & 9.1 & 4.0 & 4.9 & 28.6 & 20.7 \\
\hline Craft Workers & 1.8 & 0.0 & 20.2 & 1.8 & 17.4 & 0.9 & 55.0 & 0.9 \\
\hline Operatives & na & na & na & na & na & na & na & na \\
\hline Laborers \& Helpers & na & na & na & na & na & na & na & na \\
\hline Service Workers & 2.9 & 2.2 & 26.1 & 35.8 & 10.7 & 4.4 & 9.3 & 4.1 \\
\hline All U.S. employees & 4.9 & 3.7 & 8.6 & 5.3 & 18.8 & 8.2 & 33.3 & 13.5 \\
\hline \multicolumn{9}{|c|}{ Occupation as \% of all employees in USA } \\
\hline Executive/SR Officials \& Managers & 0.0 & 0.0 & 0.0 & 0.0 & 0.1 & 0.1 & 0.3 & 0.1 \\
\hline First/Mid Officials \& Managers & 4.1 & 4.3 & 6.9 & 5.1 & 14.4 & 12.2 & 15.7 & 14.3 \\
\hline Professionals & 11.7 & 8.8 & 17.7 & 14.1 & 71.8 & 66.6 & 39.4 & 31.0 \\
\hline Technicians & 12.5 & 6.2 & 12.2 & 8.9 & 2.8 & 3.4 & 10.0 & 6.8 \\
\hline Sales Workers & 51.4 & 42.8 & 42.9 & 42.2 & 7.3 & 9.1 & 22.4 & 26.5 \\
\hline Administrative Support & 19.8 & 37.4 & 17.2 & 23.6 & 3.0 & 8.1 & 11.8 & 21.1 \\
\hline Craft Workers & 0.0 & 0.0 & 0.3 & 0.0 & 0.1 & 0.0 & 0.2 & 0.0 \\
\hline Operatives & 0.0 & 0.0 & 0.0 & 0.0 & 0.0 & 0.0 & 0.0 & 0.0 \\
\hline Laborers \& Helpers & 0.0 & 0.0 & 0.0 & 0.0 & 0.0 & 0.0 & 0.0 & 0.0 \\
\hline Service Workers & 0.5 & 0.5 & 2.8 & 6.1 & 0.5 & 0.5 & 0.3 & 0.3 \\
\hline All U.S. employees & 100.0 & 100.0 & 100.0 & 100.0 & 100.0 & 100.0 & 100.0 & 100.0 \\
\hline
\end{tabular}

Source: Apple 2017 EEO-1 report to the U.S. Equal Opportunity Employment Commission 
While the distribution of professional jobs by race, ethnicity, and gender is similar at Intel and Apple, the presence of large numbers of sales workers at Apple demonstrates the need to examine diversity in particular companies individually rather than simply looking at aggregate data for the tech industry. The need for company-specific analysis is even more clearly the case for Amazon, which has released its EEO-1 reports for 2014, 2015, 2016, 2019, and 2020. While Amazon employed almost 102,000 professionals in the United States in 2020, the company also employed 622,000 laborers \& helpers in its warehouses and for deliveries.

Like software giant Microsoft (founded in 1975), Amazon (founded in 1993) is headquartered in Seattle, outside of Silicon Valley. Nevertheless, both companies epitomize the New Economy business model. ${ }^{57}$ As can be seen in Table V.17, in 2014 Amazon employed over 18,266 professionals in the United States-18 percent more than Apple in that year. And while Apple increased its U.S. employment of professionals by almost one and a half times between 2014 and 2020, Amazon's U.S. professional headcount exploded by more than five and a half time to 101,965 at the end of the period. Driving this enormous increase in Amazon's demand for engineers and programmers was the expansion of Amazon Web Services (AWS), the "secret to Amazon's success," as Lazonick puts it in a 2018 New York Times op-ed. ${ }^{58}$

Table V.17: U.S. employees at Amazon by EEO-1 occupational categories, 2014, 2015, 2016, 2019, and 2020

\begin{tabular}{|c|c|c|c|c|c|c|c|c|c|c|}
\hline & \multicolumn{5}{|c|}{ Number of U.S. employees } & \multicolumn{5}{|c|}{$\%$ of all employees } \\
\hline & 2014 & 2015 & 2016 & 2019 & 2020 & 2014 & 2015 & 2016 & 2019 & 2020 \\
\hline Executive/SR Officials \& Managers & 110 & 107 & 105 & 2,113 & 2,610 & 0.1 & 0.1 & 0.1 & 0.4 & 0.3 \\
\hline First/Mid Officials \& Managers & 6,863 & 9,474 & 13,352 & 26,055 & 47,634 & 8.9 & 8.3 & 7.7 & 4.8 & 5.2 \\
\hline Professionals & 18,266 & 23,480 & 30,433 & 77,007 & 101,965 & 23.7 & 20.6 & 17.4 & 14.3 & 11.1 \\
\hline Technicians & 788 & 1,371 & 1,745 & 5,434 & 7,100 & 1.0 & 1.2 & 1.0 & 1.0 & 0.8 \\
\hline Sales Workers & 641 & 715 & 965 & 64,998 & 70,307 & 0.8 & 0.6 & 0.6 & 12.0 & 7.7 \\
\hline Administrative Support & 4,445 & 5,136 & 7,720 & 17,718 & 20,794 & 5.8 & 4.5 & 4.4 & 3.3 & 2.3 \\
\hline Craft Workers & 599 & 469 & 427 & 649 & 843 & 0.8 & 0.4 & 0.2 & 0.1 & 0.1 \\
\hline Operatives & 3,930 & 5,240 & 6,471 & 26,271 & 37,674 & 5.1 & 4.6 & 3.7 & 4.9 & 4.1 \\
\hline Laborers \& Helpers & 41,521 & 68,059 & 113,198 & 311,022 & 622,077 & 53.8 & 59.7 & 64.9 & 57.6 & 67.7 \\
\hline Service Workers & 16 & 13 & 33 & 8,288 & 7,257 & 0.0 & 0.0 & 0.0 & 1.5 & 0.8 \\
\hline All employees & 77,179 & 114,064 & 174,449 & 539,555 & 918,261 & 100.0 & 100.0 & 100.0 & 100.0 & 100.0 \\
\hline
\end{tabular}

Source: Amazon EEO-1 reports to the U.S. Equal Opportunity Employment Commission.

In 1993, Jeff Bezos had decided to found Amazon in Seattle because of the presence of Microsoft as a large-scale employer of software engineers there. A quarter of a century later, Amazon's own rapid expansion placed pressure on the capacity for the Seattle metropolitan area to absorb more professionals, leading Amazon to conduct a highly publicized search - or more accurately, contest - for a second location in which to employ large numbers of highly qualified personnel. On November 13, 2018, Amazon revealed its decision to locate its "second" headquarters in both the New York City area and northern Virginia, close to Washington, DC, with a view to employing 50,000 professionals in the two places. ${ }^{59}$ As a result of backlash from

\footnotetext{
${ }^{57}$ Lazonick, Sustainable Prosperity, chs. 1-2.

${ }^{58}$ William Lazonick, “The secret of Amazon's success," New York Times, November 19, 2018, at https://www.nytimes.com/2018/11/19/opinion/amazon-bezos-hq2.html.

${ }^{59}$ Erin Durkin, “Amazon HQ2: tech giant splits new home across New York City and Virginia,” Guardian, November 13, 2020, at https://www.theguardian.com/technology/2018/nov/13/amazon-hq2-second-headquarters-new-york-city-virginia.
} 
opposition groups in New York City, however, Amazon subsequently dropped its plan to build a new campus there. ${ }^{60}$

In 2016 Amazon recorded R\&D expenditures of $\$ 16.1$ billion, a one-year record for any company, which Amazon increased to $\$ 42.7$ billion in 2020 and $\$ 56.1$ billion in 2021. Central to this explosion in R\&D spending-which Amazon calls "technology and content"- has been investments in professionals who work for AWS, which has provided Amazon with unique capability to sell millions of different products on its retail websites around the world while it also sells its cloud computing services to other organizations, including government agencies. For the half-decade 2017-2021, AWS accounted for 12 percent of Amazon's total sales but 67 percent of its operating income. North American retail sales were 60 percent of total sales and contributed 42 percent of operating income, while international retail sales were 28 percent of total sales and imposed a nine-percent loss on Amazon's total operating income.

In contrast to the high-paid professionals whom the company employs in AWS, the hundreds of thousands of Amazon's employees in retail sales are low-paid laborers \& helpers. In October 2018, Amazon was in the headlines when CEO Jeff Bezos announced that, as of November 1, the company would pay more than 350,000 employees in the United States a minimum of $\$ 15$ per hour. ${ }^{61}$ There was criticism that some hourly employees would actually make less under the new scheme because the company terminated a program dating back to 2002 of granting all fulltime hourly employees one or two restricted stock units per year as part of their compensation. ${ }^{62}$ The total annual compensation of \$31,200-per-year yielded by Amazon's \$15 minimum wage is low-paid work by American standards.

In 2014 the company employed 42,521 laborers \& helpers in its warehouses and for delivery services in the United States (see Table V.17). These numbers almost tripled by 2016 and tripling again by 2019, at the end of which Amazon employed 311,022 laborers \& helpers in the United States. During 2020, with North American sales increasing from \$236 billion to \$280 billion, Amazon doubled its U.S. laborers-\&-helpers workforce to 622,027.

Table V.18 documents the percent distribution by race, ethnicity, and gender of the increase of 841,082 in Amazon U.S. employees from 2014 to 2020. Of the total increase, 69.0 percent were laborers $\&$ helpers, 8.3 percent were sales workers, and 10.0 percent were professionals. All race, ethnic, and gender groups participated in the increase in laborers \& helpers, ranging from a low of 50.0 percent of the total net increase of 110,792 Asian employees to 79.6 percent of the total net increase of 202,541 Hispanic employees, and 84.7 percent of the total net increase of 226,392 Black employees. Of the 558,556 additional laborers \& helpers in 2020 compared with 2014, Blacks filled 33.0 percent and Hispanics 27.8 percent of the positions. The employment gains of Blacks and Hispanics were almost entirely confined to that low-paid occupational category, with employment gains as sales workers representing the next largest category, at 5.2 percent for Blacks and 8.1 percent for Hispanics. In contrast, the professionals category accounted for 35.3

${ }^{60}$ Dennis Green, “Amazon cancels New York HQ2,” Business Insider, February 14, 2019, at https://www.businessinsider.com/amazon-cancels-new-york-hq2-2019-

2\#: : :text=Amazon $\% 20$ has $\% 20$ canceled $\% 20$ its $\% 20 H Q 2$,Queens $\% 2 \mathrm{C} \% 22 \% 20$ the $\% 20$ company $\% 20$ wrote.

${ }^{61}$ Karen Weise, “Amazon to raise minimum wage to $\$ 15$ for all U.S, workers," New York Times, October 2, 2018, at https://www.nytimes.com/2018/10/02/business/amazon-minimum-wage.html.

${ }^{62}$ Tami Luhby, "Amazon eliminates bonuses and stock awards for hourly workers," CNN Business, October 4, 2018, at https://www.cnn.com/2018/10/04/business/amazon-minimum-wage-bonus/index.html. 
percent of the total employment increase for Asians, who gained an additional 33,687 positions from 2014 to 2020 compared with 3,592 for Blacks and 4,910 for Hispanics.

Table V.18: Distribution of Amazon's U.S. employment gains from 2014 to 2020 by gender, race, and ethnicity and by occupational category

\begin{tabular}{|c|c|c|c|c|c|c|c|c|}
\hline & $\begin{array}{c}\text { Total } \\
\text { change }\end{array}$ & Female & Male & Black & Hispanic & Asian & White & Other \\
\hline \multicolumn{9}{|c|}{ Change 2014-2020 in number of Amazon employees in USA, by gender, racial, or ethnic group and by occupation } \\
\hline Executive/SR Officials \& Managers & 2,500 & 609 & 1,891 & 92 & 107 & 502 & 1,751 & 48 \\
\hline First/Mid Officials \& Managers & 40,771 & 12,603 & 28,168 & 5,055 & 5,038 & 6,486 & 22,573 & 1,619 \\
\hline Professionals & 83,699 & 27,437 & 56,262 & 3,592 & 4,910 & 39,078 & 33,687 & 2,432 \\
\hline Technicians & 6,312 & 1,316 & 4,996 & 838 & 1,078 & 634 & 3,391 & 371 \\
\hline Sales Workers & 69,666 & 34,287 & 35,379 & 11,787 & 16,381 & 4,671 & 33,537 & 3,290 \\
\hline Administrative Support & 16,349 & 10,287 & 6,062 & 3,591 & 2,988 & 1,402 & 7,182 & 1,186 \\
\hline Craft Workers & 244 & -5 & 249 & 23 & 86 & 11 & 103 & 21 \\
\hline Operatives & 33,744 & 12,802 & 20,942 & 8,122 & 8,171 & 2,047 & 13,432 & 1,972 \\
\hline Laborers \& Helpers & 580,556 & 295,487 & 285,069 & 191,757 & 161,309 & 55,435 & 141,474 & 30,581 \\
\hline Service Workers & 7,241 & 2,458 & 4,783 & 1,534 & 2,473 & 526 & 2,415 & 293 \\
\hline All employees & 841,082 & 397,281 & 443,801 & 226,391 & 202,541 & 110,792 & 259,545 & 41,813 \\
\hline \multicolumn{9}{|c|}{ \% change 2014-2020 in number of Amazon employees in USA, by occupation within gender, racial, or ethnic group } \\
\hline Executive/SR Officials \& Managers & 0.3 & 0.2 & 0.4 & 0.0 & 0.1 & 0.5 & 0.7 & 0.1 \\
\hline First/Mid Officials \& Managers & 4.8 & 3.2 & 6.3 & 2.2 & 2.5 & 5.9 & 8.7 & 3.9 \\
\hline Professionals & 10.0 & 6.9 & 12.7 & 1.6 & 2.4 & 35.3 & 13.0 & 5.8 \\
\hline Technicians & 0.8 & 0.3 & 1.1 & 0.4 & 0.5 & 0.6 & 1.3 & 0.9 \\
\hline Sales Workers & 8.3 & 8.6 & 8.0 & 5.2 & 8.1 & 4.2 & 12.9 & 7.9 \\
\hline Administrative Support & 1.9 & 2.6 & 1.4 & 1.6 & 1.5 & 1.3 & 2.8 & 2.8 \\
\hline Craft Workers & 0.0 & 0.0 & 0.1 & 0.0 & 0.0 & 0.0 & 0.0 & 0.1 \\
\hline Operatives & 4.0 & 3.2 & 4.7 & 3.6 & 4.0 & 1.8 & 5.2 & 4.7 \\
\hline Laborers \& Helpers & 69.0 & 74.4 & 64.2 & 84.7 & 79.6 & 50.0 & 54.5 & 73.1 \\
\hline Service Workers & 0.9 & 0.6 & 1.1 & 0.7 & 1.2 & 0.5 & 0.9 & 0.7 \\
\hline All employees & 100.0 & 100.0 & 100.0 & 100.0 & 100.0 & 100.0 & 100.0 & 100.0 \\
\hline \multicolumn{9}{|c|}{ \% change in employment, 2014-2020 of gender, racial, or ethnic group, within occupation } \\
\hline Executive/SR Officials \& Managers & 100.0 & 24.4 & 75.6 & 3.7 & 4.3 & 20.1 & 70.0 & 1.9 \\
\hline First/Mid Officials \& Managers & 100.0 & 30.9 & 69.1 & 12.4 & 12.4 & 15.9 & 55.4 & 4.0 \\
\hline Professionals & 100.0 & 32.8 & 67.2 & 4.3 & 5.9 & 46.7 & 40.2 & 2.9 \\
\hline Technicians & 100.0 & 20.8 & 79.2 & 13.3 & 17.1 & 10.0 & 53.7 & 5.9 \\
\hline Sales Workers & 100.0 & 49.2 & 50.8 & 16.9 & 23.5 & 6.7 & 48.1 & 4.7 \\
\hline Administrative Support & 100.0 & 62.9 & 37.1 & 22.0 & 18.3 & 8.6 & 43.9 & 7.3 \\
\hline Craft Workers & 100.0 & -2.0 & 102.0 & 9.4 & 35.2 & 4.5 & 42.2 & 8.6 \\
\hline Operatives & 100.0 & 37.9 & 62.1 & 24.1 & 24.2 & 6.1 & 39.8 & 5.8 \\
\hline Laborers \& Helpers & 100.0 & 50.9 & 49.1 & 33.0 & 27.8 & 9.5 & 24.4 & 5.3 \\
\hline Service Workers & 100.0 & 33.9 & 66.1 & 21.2 & 34.2 & 7.3 & 33.4 & 4.0 \\
\hline All employees & 100.0 & 47.2 & 52.8 & 26.9 & 24.1 & 13.2 & 30.9 & 5.0 \\
\hline
\end{tabular}

Source: Amazon EEO-1 reports to the U.S. Equal Opportunity Employment Commission.

As shown in Table V.19, Blacks as a proportion of the Amazon U.S.-based labor force increased from 14.8 percent in 2014 to 25.9 percent in 2020. In the context of Amazon's explosive employment growth, Blacks made substantial gains in all occupational categories, but it was as laborers \& helpers that their numbers soared. 
Table V.19: Blacks in Amazon's U.S.-based labor force, 2014, 2015, 2016, 2019, and 2020

\begin{tabular}{|c|c|c|c|c|c|}
\hline & 2014 & 2015 & 2016 & 2019 & 2020 \\
\hline \multicolumn{6}{|c|}{ Total number of Amazon employees in the United States } \\
\hline & 77,179 & 117,084 & 174,449 & 539,555 & 918,261 \\
\hline \multicolumn{6}{|c|}{ Amazon's U.S. employees as \% of world wide employees } \\
\hline & 56.9 & 59.3 & 61.0 & 71.0 & 78.3 \\
\hline \multicolumn{6}{|c|}{ Number of Black Amazon employees in USA, by occupation } \\
\hline Officials \& Managers & 291 & 433 & 733 & 2,334 & 5,438 \\
\hline Professionals & 375 & 540 & 798 & 2,470 & 3,967 \\
\hline Technicians & 68 & 112 & 171 & 568 & 906 \\
\hline Sales Workers & 27 & 27 & 44 & 11,853 & 11,814 \\
\hline Administrative Support & 287 & 447 & 1,249 & 3,031 & 3,878 \\
\hline Craft Workers & 37 & 33 & 26 & 54 & 60 \\
\hline Operatives & 512 & 765 & 1,052 & 5,357 & 8,634 \\
\hline Laborers \& Helpers & 9,787 & 18,341 & 33,379 & 109,827 & 201,544 \\
\hline Service Workers & 8 & 6 & 11 & 1,860 & 1,542 \\
\hline All Black employees in USA & 11,392 & 20,704 & 37,463 & 137,354 & 237,783 \\
\hline \multicolumn{6}{|c|}{ Blacks as \% of all Amazon employees in USA, by occupation } \\
\hline Officials \& Managers & 4.2 & 4.5 & 5.4 & 8.3 & 10.8 \\
\hline Professionals & 2.1 & 2.3 & 2.6 & 3.2 & 3.9 \\
\hline Technicians & 8.6 & 8.2 & 9.8 & 10.5 & 12.8 \\
\hline Sales Workers & 4.2 & 3.8 & 4.6 & 18.2 & 16.8 \\
\hline Administrative Support & 6.5 & 8.7 & 16.2 & 17.1 & 18.6 \\
\hline Craft Workers & 6.2 & 7.0 & 6.1 & 8.3 & 7.1 \\
\hline Operatives & 13.0 & 14.6 & 16.3 & 20.4 & 22.9 \\
\hline Laborers \& Helpers & 23.6 & 26.9 & 29.5 & 35.3 & 32.4 \\
\hline Service Workers & 50.0 & 46.2 & 33.3 & 22.4 & 21.2 \\
\hline All U.S. employees & 14.8 & 18.2 & 21.5 & 25.5 & 25.9 \\
\hline \multicolumn{6}{|c|}{ Blacks by occupation as \% of all Black Amazon employees in USA, by occupation } \\
\hline Officials \& Managers & 2.6 & 2.1 & 2.0 & 1.7 & 2.3 \\
\hline Professionals & 3.3 & 2.6 & 2.1 & 1.8 & 1.7 \\
\hline Technicians & 0.6 & 0.5 & 0.5 & 0.4 & 0.4 \\
\hline Sales Workers & 0.2 & 0.1 & 0.1 & 8.6 & 5.0 \\
\hline Administrative Support & 2.5 & 2.2 & 3.3 & 2.2 & 1.6 \\
\hline Craft Workers & 0.3 & 0.2 & 0.1 & 0.0 & 0.0 \\
\hline Operatives & 4.5 & 3.7 & 2.8 & 3.9 & 3.6 \\
\hline Laborers \& Helpers & 85.9 & 88.6 & 89.1 & 80.0 & 84.8 \\
\hline Service Workers & 0.1 & 0.0 & 0.0 & 1.4 & 0.6 \\
\hline All Black employees in USA & 100.0 & 100.0 & 100.0 & 100.0 & 100.0 \\
\hline
\end{tabular}

Table V.20 compares the racial, ethnic, and gender distribution of Amazon's U.S. jobs by occupation for whites, Blacks, Hispanics, and Asians in 2020, distinguishing between males and females in each occupation. Blacks are the only group in which there was a larger number of female than male employees (the numbers for Hispanic females and males are virtually identical), and in the laborers \& helpers category Black females ( 86.7 percent) are even more concentrated than Black males (82.5 percent). Asians and whites dominate the professionals category, but there is a huge gender imbalance in favor of males among both groups. The representation of Asian males as professionals is about five times their share of the U.S. 
population, while the representation of both Black males and Black females among laborers \& helpers is about seven times their shares of the U.S. population.

Table V.20: Racial, ethnic, and gender composition of Amazon's U.S.-based labor force, 2020

\begin{tabular}{|c|c|c|c|c|c|c|c|c|}
\hline 2020 & $\begin{array}{l}\text { Black } \\
\text { males }\end{array}$ & $\begin{array}{c}\text { Black } \\
\text { females }\end{array}$ & $\begin{array}{c}\text { Hispanic } \\
\text { males }\end{array}$ & $\begin{array}{c}\text { Hispanic } \\
\text { females }\end{array}$ & $\begin{array}{l}\text { Asian } \\
\text { males }\end{array}$ & $\begin{array}{c}\text { Asian } \\
\text { females }\end{array}$ & $\begin{array}{l}\text { White } \\
\text { males }\end{array}$ & $\begin{array}{l}\text { White } \\
\text { females }\end{array}$ \\
\hline \multicolumn{9}{|l|}{ Number of Amazon employees in USA } \\
\hline Executive/SR Officials \& Managers & 56 & 37 & 83 & 26 & 416 & 93 & 1,396 & 454 \\
\hline First/Mid Officials \& Managers & 3,414 & 1,931 & 3,669 & 1,654 & 5,809 & 1,944 & 19,593 & 7,835 \\
\hline Professionals & 2,230 & 1,737 & 3,703 & 1,810 & 31,643 & 14,039 & 30,608 & 13,262 \\
\hline Technicians & 736 & 170 & 859 & 267 & 564 & 148 & 3,206 & 748 \\
\hline Sales Workers & 5,709 & 6,105 & 8,628 & 7,772 & 2,363 & 2,356 & 17,460 & 16,602 \\
\hline Administrative Support & 1,069 & 2,809 & 1,387 & 1,825 & 602 & 1,019 & 4,218 & 6,482 \\
\hline Craft Workers & 59 & 1 & 120 & 5 & 30 & 0 & 575 & 11 \\
\hline Operatives & 5,015 & 3,619 & 5,451 & 3,118 & 1,483 & 672 & 10,520 & 5,641 \\
\hline Laborers \& Helpers & 90,815 & 110,729 & 79,236 & 87,211 & 31,828 & 25,317 & 90,357 & 74,309 \\
\hline Service Workers & 1,030 & 512 & 1,553 & 921 & 345 & 182 & 1,677 & 744 \\
\hline All U.S. employees & 110,133 & 127,650 & 104,689 & 104,609 & 75,083 & 45,770 & 179,510 & 126,088 \\
\hline \multicolumn{9}{|c|}{$\%$ of all Amazon employees in USA, by occupation } \\
\hline Executive/SR Officials \& Managers & 2.1 & 1.4 & 3.2 & 1.0 & 15.9 & 3.6 & 53.5 & 17.4 \\
\hline First/Mid Officials \& Managers & 7.2 & 4.1 & 7.7 & 3.5 & 12.2 & 4.1 & 41.1 & 16.4 \\
\hline Professionals & 2.2 & 1.7 & 3.6 & 1.8 & 31.0 & 13.8 & 30.0 & 13.0 \\
\hline Technicians & 10.4 & 2.4 & 12.1 & 3.8 & 7.9 & 2.1 & 45.2 & 10.5 \\
\hline Sales Workers & 8.1 & 8.7 & 12.3 & 11.1 & 3.4 & 3.4 & 24.8 & 23.6 \\
\hline Administrative Support & 5.1 & 13.5 & 6.7 & 8.8 & 2.9 & 4.9 & 20.3 & 31.2 \\
\hline Craft Workers & 7.0 & 0.1 & 14.2 & 0.6 & 3.6 & 0.0 & 68.2 & 1.3 \\
\hline Operatives & 13.3 & 9.6 & 14.5 & 8.3 & 3.9 & 1.8 & 27.9 & 15.0 \\
\hline Laborers \& Helpers & 14.6 & 17.8 & 12.7 & 14.0 & 5.1 & 4.1 & 14.5 & 11.9 \\
\hline Service Workers & 14.2 & 7.1 & 21.4 & 12.7 & 4.8 & 2.5 & 23.1 & 10.3 \\
\hline All U.S. employees & 12.0 & 13.9 & 11.4 & 11.4 & 8.2 & 5.0 & 19.6 & 13.7 \\
\hline \multicolumn{9}{|c|}{ Occupation as \% of all employees in USA } \\
\hline Executive/SR Officials \& Managers & 0.1 & 0.0 & 0.1 & 0.0 & 0.6 & 0.2 & 0.8 & 0.4 \\
\hline First/Mid Officials \& Managers & 3.1 & 1.5 & 3.5 & 1.6 & 7.7 & 4.2 & 10.9 & 6.2 \\
\hline Professionals & 2.0 & 1.4 & 3.5 & 1.7 & 42.1 & 30.7 & 17.0 & 10.5 \\
\hline Technicians & 0.7 & 0.1 & 0.8 & 0.3 & 0.8 & 0.3 & 1.8 & 0.6 \\
\hline Sales Workers & 5.2 & 4.8 & 8.2 & 7.4 & 3.1 & 5.1 & 9.7 & 13.2 \\
\hline Administrative Support & 1.0 & 2.2 & 1.3 & 1.7 & 0.8 & 2.2 & 2.3 & 5.1 \\
\hline Craft Workers & 0.1 & 0.0 & 0.1 & 0.0 & 0.0 & 0.0 & 0.3 & 0.0 \\
\hline Operatives & 4.6 & 2.8 & 5.2 & 3.0 & 2.0 & 1.5 & 5.9 & 4.5 \\
\hline Laborers \& Helpers & 82.5 & 86.7 & 75.7 & 83.4 & 42.4 & 55.3 & 50.3 & 58.9 \\
\hline Service Workers & 0.9 & 0.4 & 1.5 & 0.9 & 0.5 & 0.4 & 0.9 & 0.6 \\
\hline All U.S. employees & 100.0 & 100.0 & 100.0 & 100.0 & 100.0 & 100.0 & 100.0 & 100.0 \\
\hline
\end{tabular}

Source: Amazon EEO-1 reports to the U.S. Equal Opportunity Employment Commission.

These disparities on the basis of race, ethnicity, and gender prevail at all the tech companies that have released their EEO-1 submissions. Table V.21 compares the employment by race/ethnicity/gender and occupation at the 12 tech companies in the San Francisco Bay Area with the largest numbers of U.S. employees among tech firms that made their EEO-1 reports available in either 2016 or 2017. In all, these 12 companies employed over 600,000 people in the United States, ranging from 9,382 at Uber (2017) to 174,449 at Amazon (2016). All of these companies except HP Inc. and Hewlett-Packard Enterprise (HPE) - the only formerly Old Economy companies in the group - employed between 50 percent and 70 percent of their worldwide labor force in the United States.

As shown in Table V.21, Blacks make up less than four percent of the labor force at seven of the 12 companies. These are companies that employ very few people in the last four "blue collar" occupational categories, as shown in Table V.22. We have seen that Amazon, with is distribution facilities, and Apple, with its retail stores, employ high proportions of Blacks, predominantly in 
low-paid work. Data displayed in Table V.21, published by companies since 2017/2018 in compliance with the SEC's Pay Ratio Disclosure Rule, reflect the vast difference in median pay between, at one extreme, \$240,420 at Facebook, where in 201792.9 percent of 19,679 U.S. employee were in the top three occupational categories, and, at the other extreme, \$28,446 at Amazon, where in 201664.9 percent of 174,449 U.S. employees were laborers \& helpers. ${ }^{63}$

Table V.21: Comparison of employment by gender, race, or ethnicity and by occupation in the U.S.-based labor forces of 12 major tech companies, 2016 or 2017

\begin{tabular}{|c|c|c|c|c|c|c|c|c|c|c|c|c|}
\hline & Amazon & Apple & Microsoft & Alphabet & Intel & HPE & Cisco & Facebook & Salesforce & HP Inc & PayPal & Uber \\
\hline \multicolumn{13}{|c|}{ Total number of the company's employees in USA } \\
\hline & 174,449 & 83,759 & 74,427 & 55,546 & 54,135 & 51,989 & 37,526 & 19,679 & 18,264 & 13,613 & 10,357 & 9,382 \\
\hline \multicolumn{13}{|c|}{ The company's U.S. employees as a percent of worldwide employees } \\
\hline & 61.0 & 66.9 & 60.0 & 69.3 & 51.9 & 24.8 & 50.9 & 78.4 & 62.1 & 28.1 & 55.4 & 58.6 \\
\hline \multicolumn{13}{|c|}{ Annual earnings of the median employee in the company } \\
\hline & $\$ 28,446$ & na & $\$ 167,689$ & $\$ 197,274$ & $\$ 102,100$ & na & $\$ 132,764$ & $\$ 240,420$ & $\$ 155,284$ & $\$ 92,800$ & $\$ 70,228$ & na \\
\hline \multicolumn{13}{|c|}{ Number of the company's employees in USA by race, ethnicity, or gender } \\
\hline Black or African American & 37,463 & 7,710 & 2,932 & 1,343 & 2,108 & 3,734 & 1,283 & 612 & 492 & 519 & 822 & 764 \\
\hline Hispanic & 22,794 & 11,098 & 4,340 & 2,954 & 4,362 & 2,987 & 1,913 & 1,104 & 730 & 1,087 & 761 & 727 \\
\hline Asian & 22,475 & 17,944 & 23,884 & 19,830 & 19,448 & 6,634 & 13,491 & 7,952 & 4,612 & 1,671 & 3,134 & 2,799 \\
\hline White & 83,208 & 44,176 & 41,375 & 29,905 & 26,921 & 37,771 & 20,344 & 9,251 & 11,868 & 10,066 & 5,426 & 4,636 \\
\hline Native Hawaiian or Pacific Isiander & 794 & 385 & 161 & 112 & 299 & 80 & 55 & 61 & 57 & 21 & 23 & 27 \\
\hline American Indian or Native Alaskan & 1,016 & 298 & 357 & 58 & 306 & 206 & 92 & 21 & 29 & 63 & 23 & 28 \\
\hline Two or more races & 6,699 & 2,148 & 1,378 & 1,344 & 691 & 577 & 348 & 678 & 476 & 186 & 168 & 401 \\
\hline Female & 71,584 & 26,064 & 20,090 & 16,417 & 14,051 & 17,195 & 9,845 & 6,725 & 6,010 & 4,220 & 4,371 & 3,055 \\
\hline Male & 102,865 & 57,695 & 54,337 & 39,129 & 40,084 & 34,794 & 27,681 & 12,954 & 12,254 & 9,393 & 5,986 & 6,327 \\
\hline \multicolumn{13}{|c|}{$\%$ of the company's employees in USA by race, ethnicity, or gender } \\
\hline Black or African American & 21.5 & 9.2 & 3.9 & 2.4 & 3.9 & 7.2 & 3.4 & 3.1 & 2.7 & 3.8 & 7.9 & 8.1 \\
\hline Hispanic & 13.1 & 13.2 & 5.8 & 5.3 & 8.1 & 5.7 & 5.1 & 5.6 & 4.0 & 8.0 & 7.3 & 7.7 \\
\hline Asian & 12.9 & 21.4 & 32.1 & 35.7 & 35.9 & 12.8 & 36.0 & 40.4 & 25.3 & 12.3 & 30.3 & 29.8 \\
\hline White & 47.7 & 52.7 & 55.6 & 53.8 & 49.7 & 72.7 & 54.2 & 47.0 & 65.0 & 73.9 & 52.4 & 49.4 \\
\hline Native Hawaiian or Pacific Isiander & 0.5 & 0.5 & 0.2 & 0.2 & 0.6 & 0.2 & 0.1 & 0.3 & 0.3 & 0.2 & 0.2 & 0.3 \\
\hline American Indian or Native Alaskan & 0.6 & 0.4 & 0.5 & 0.1 & 0.6 & 0.4 & 0.2 & 0.1 & 0.2 & 0.5 & 0.2 & 0.3 \\
\hline Two or more races & 3.8 & 2.6 & 1.9 & 2.4 & 1.3 & 1.1 & 0.9 & 3.4 & 2.6 & 1.4 & 1.6 & 4.3 \\
\hline All U.S. employees & 100.0 & 100.0 & 100.0 & 100.0 & 100.0 & 100.0 & 100.0 & 100.0 & 100.0 & 100.0 & 100.0 & 100.0 \\
\hline Female & 41.0 & 31.1 & 27.0 & 29.6 & 26.0 & 33.1 & 26.2 & 34.2 & 32.9 & 31.0 & 42.2 & 32.6 \\
\hline Male & 59.0 & 68.9 & 73.0 & 70.4 & 74.0 & 66.9 & 73.8 & 65.8 & 67.1 & 69.0 & 57.8 & 67.4 \\
\hline \multicolumn{13}{|c|}{ Occupational category as \% of the company's employees in USA } \\
\hline Executive/SR Officials \& Managers & 0.1 & 0.1 & 0.7 & 0.5 & 0.2 & 1.2 & 0.8 & 3.9 & 1.7 & 1.5 & 0.8 & 2.0 \\
\hline First/Mid Officials \& Managers & 7.7 & 10.9 & 14.9 & 23.4 & 12.4 & 11.4 & 14.9 & 14.3 & 17.9 & 14.3 & 19.0 & 16.1 \\
\hline Professionals & 17.4 & 32.2 & 75.0 & 69.2 & 66.8 & 65.6 & 71.0 & 74.7 & 57.2 & 53.6 & 49.2 & 55.6 \\
\hline Technicians & 1.0 & 17.9 & 0.8 & 0.7 & 15.7 & 7.1 & 0.1 & 1.3 & 0.0 & 14.8 & 0.0 & 0.8 \\
\hline Sales Workers & 0.6 & 31.2 & 7.5 & 4.1 & 2.4 & 8.6 & 11.5 & 2.5 & 20.8 & 11.7 & 6.1 & 1.9 \\
\hline Administrative Support & 4.4 & 6.9 & 1.0 & 1.6 & 1.8 & 5.6 & 1.6 & 2.7 & 2.4 & 4.0 & 24.9 & 18.4 \\
\hline Craft Workers & 0.2 & 0.1 & 0.0 & 0.0 & 0.7 & 0.0 & 0.0 & 0.1 & 0.0 & 0.0 & 0.0 & 0.0 \\
\hline Operatives & 3.7 & 0.0 & 0.0 & 0.0 & 0.0 & 0.1 & 0.0 & 0.0 & 0.0 & 0.0 & 0.0 & 5.2 \\
\hline Laborers \& Helpers & 64.9 & 0.0 & 0.0 & 0.0 & 0.0 & 0.4 & 0.0 & 0.0 & 0.0 & 0.0 & 0.0 & 0.0 \\
\hline Service Workers & 0.0 & 0.7 & 0.0 & 0.4 & 0.0 & 0.0 & 0.0 & 0.6 & 0.0 & 0.0 & 0.0 & 0.0 \\
\hline All U.S. employees & 100.0 & 100.0 & 100.0 & 100.0 & 100.0 & 100.0 & 100.0 & 100.0 & 100.0 & 100.0 & 100.0 & 100.0 \\
\hline
\end{tabular}

Note: Data are for fiscal year 2016 for Amazon, Intel, Hewlett Packard Enterprise (HPE), Cisco, and HP Inc.; and for fiscal year 2017 for Apple, Microsoft, Alphabet, Facebook, Salesforce, PayPal, and Uber.

Sources: Company EEO-1 reports to the U.S. Equal Opportunity Employment Commission. Median pay data are from company proxy statements and AFL-CIO, "Company Pay Ratios," at https://aflcio.org/paywatch/company-pay-ratios; Marlize von Romburgh, "How much the CEOs of Facebook, Alphabet, Intel, Twitter, eBay, Tesla, ad other big Bay Area tech employers make compared to their workers," Silicon Valley Business journal, June 5, 2018, at https://www.bizjournals.com/sanjose/news/2018/06/05/tech-ceo-pay-ratiofb-goog-intc-twtr-tsla-nflx-crm.html.

At 8.1 percent of its U.S. labor force, the Black representation at Uber was also relatively high among these 12 companies, mainly because of Blacks - two-thirds of them female - employed in administrative support. At PayPal, Black overall representation was 7.9 percent because of their high concentrations as sales workers and administrative support, with females predominating in these occupations (see Table V.22). Finally, there was a relatively high proportion of Blacks (7.2

${ }^{63}$ These median pay data are for worldwide employees. Note that in 2018 Amazon declared that the median pay of its U.S. employees was $\$ 34,123$. See Weise, “Amazon to raise minimum wage to $\$ 15$ for all U.S, workers." 
percent of its U.S.-based labor force) at HPE with strengths as professionals (43 percent female), technicians (28 percent), and administrative support (81 percent).

Table V.22: Comparison of employment of Blacks in the U.S.-based labor forces of 12 major tech companies, 2016 or 2017

\begin{tabular}{|c|c|c|c|c|c|c|c|c|c|c|c|c|}
\hline & Amazon & Apple & Microsoft & Alphabet & Intel & HPE & Cisco & Facebook & Salesforce & HP Inc & PayPal & Uber \\
\hline \multicolumn{13}{|c|}{ Number of the company's Black employees in USA, by occupation } \\
\hline Executive/SR Officials \& Managers & 0 & 3 & 9 & 8 & 3 & 10 & 6 & 23 & 4 & 3 & 5 & 6 \\
\hline First/Mid Officials \& Managers & 733 & 280 & 266 & 321 & 192 & 251 & 125 & 75 & 61 & 42 & 67 & 80 \\
\hline Professionals & 798 & 486 & 2,010 & 816 & 1,247 & 2,170 & 962 & 445 & 273 & 234 & 155 & 155 \\
\hline Technicians & 171 & 2,331 & 45 & 17 & 536 & 450 & 2 & 7 & 0 & 181 & 0 & 1 \\
\hline Sales Workers & 44 & 3,948 & 565 & 104 & 60 & 223 & 151 & 20 & 116 & 41 & 180 & 14 \\
\hline Administrative Support & 1,249 & 635 & 37 & 55 & 61 & 580 & 37 & 36 & 38 & 18 & 415 & 468 \\
\hline Craft Workers & 26 & 2 & 0 & 0 & 8 & 0 & 0 & 2 & 0 & 0 & 0 & 0 \\
\hline Operatives & 1,052 & 0 & 0 & 0 & 0 & 15 & 0 & 0 & 0 & 0 & 0 & 40 \\
\hline Laborers \& Helpers & 33,379 & 0 & 0 & 0 & 1 & 35 & 0 & 0 & 0 & 0 & 0 & 0 \\
\hline Service Workers & 11 & 25 & 0 & 22 & 0 & 0 & 0 & 4 & 0 & 0 & 0 & 0 \\
\hline All U.S. employees & 37,463 & 7,710 & 2,932 & 1,343 & 2,108 & 3,734 & 1,283 & 612 & 492 & 519 & 822 & 764 \\
\hline \multicolumn{13}{|c|}{ Blacks as \% of the company's employees in USA, by occupation } \\
\hline Executive/SR Officials \& Managers & 0.0 & 2.6 & 1.6 & 2.8 & 2.8 & 1.7 & 2.0 & 3.0 & 1.3 & 1.4 & 6.0 & 3.2 \\
\hline First/Mid Officials \& Managers & 5.5 & 3.1 & 2.4 & 2.5 & 2.9 & 4.2 & 2.2 & 2.7 & 1.9 & 2.2 & 3.4 & 5.3 \\
\hline Professionals & 2.6 & 1.8 & 3.6 & 2.1 & 3.4 & 6.4 & 3.6 & 3.0 & 2.6 & 3.2 & 3.0 & 3.0 \\
\hline Technicians & 9.8 & 15.6 & 7.7 & 4.2 & 6.3 & 12.2 & 6.3 & 2.8 & na & 9.0 & 0.0 & 1.4 \\
\hline Sales Workers & 4.6 & 15.1 & 10.1 & 4.6 & 4.5 & 5.0 & 3.5 & 4.0 & 3.1 & 2.6 & 28.6 & 7.8 \\
\hline Administrative Support & 16.2 & 11.0 & 4.9 & 6.0 & 6.3 & 19.9 & 6.3 & 6.8 & 8.8 & 3.3 & 16.1 & 27.1 \\
\hline Craft Workers & 6.1 & 2.0 & na & na & na & na & 0.0 & 20.0 & na & na & na & na \\
\hline Operatives & 16.3 & na & 0.0 & na & 100.0 & 22.1 & 0.0 & na & na & 0.0 & na & 8.2 \\
\hline Laborers \& Helpers & 29.5 & na & na & na & na & 19.1 & 0.0 & na & na & 0.0 & na & na \\
\hline Service Workers & 33.3 & 4.5 & na & 9.1 & na & na & 0.0 & 3.7 & 0.0 & na & na & na \\
\hline All U.S. employees & 21.5 & 9.2 & 3.9 & 2.4 & 3.9 & 7.2 & 3.4 & 3.1 & 2.7 & 3.8 & 7.9 & 8.1 \\
\hline \multicolumn{13}{|c|}{ Blacks by occupation as \% of all Black employees of the company in USA } \\
\hline Executive/SR Officials \& Managers & 0.0 & 0.0 & 0.3 & 0.6 & 0.1 & 0.3 & 0.5 & 3.8 & 0.8 & 0.6 & 0.6 & 0.8 \\
\hline First/Mid Officials \& Managers & 2.0 & 3.6 & 9.1 & 23.9 & 9.1 & 6.7 & 9.7 & 12.3 & 12.4 & 8.1 & 8.2 & 10.5 \\
\hline Professionals & 2.1 & 6.3 & 68.6 & 60.8 & 59.2 & 58.1 & 75.0 & 72.7 & 55.5 & 45.1 & 18.9 & 20.3 \\
\hline Technicians & 0.5 & 30.2 & 1.5 & 1.3 & 25.4 & 12.1 & 0.2 & 1.1 & 0.0 & 34.9 & 0.0 & 0.1 \\
\hline Sales Workers & 0.1 & 51.2 & 19.3 & 7.7 & 2.8 & 6.0 & 11.8 & 3.3 & 23.6 & 7.9 & 21.9 & 1.8 \\
\hline Administrative Support & 3.3 & 8.2 & 1.3 & 4.1 & 2.9 & 15.5 & 2.9 & 5.9 & 7.7 & 3.5 & 50.5 & 61.3 \\
\hline Craft Workers & 0.1 & 0.0 & 0.0 & 0.0 & 0.4 & 0.0 & 0.0 & 0.3 & 0.0 & 0.0 & 0.0 & 0.0 \\
\hline Operatives & 2.8 & 0.0 & 0.0 & 0.0 & 0.0 & 0.4 & 0.0 & 0.0 & 0.0 & 0.0 & 0.0 & 5.2 \\
\hline Laborers \& Helpers & 89.1 & 0.0 & 0.0 & 0.0 & 0.0 & 0.9 & 0.0 & 0.0 & 0.0 & 0.0 & 0.0 & 0.0 \\
\hline Service Workers & 0.0 & 0.3 & 0.0 & 1.6 & 0.0 & 0.0 & 0.0 & 0.7 & 0.0 & 0.0 & 0.0 & 0.0 \\
\hline All U.S. employees & 100.0 & 100.0 & 100.0 & 100.0 & 100.0 & 100.0 & 100.0 & 100.0 & 100.0 & 100.0 & 100.0 & 100.0 \\
\hline
\end{tabular}

Note that, at the two former HP companies, Blacks had a much stronger representation at HPE, an information-technology services company, than at HP Inc., a computer and printer company. The highest concentrations of Blacks at both companies were as professionals, but Blacks were 6.4 percent of this occupation at HPE and only 3.2 percent at HP Inc. With 3.8 times the number of U.S. employees as HP Inc., HPE had 9.2 times the number of professionals as well as 32.2 times the number of administrative-support employees.

Table V.23 focuses the comparison among the 12 companies on professionals employment. As stated previously, it is this occupational category that offers the greatest prospect for upward 
mobility in one of the most important industrial sectors in the United States for offering wellpaid work. In total, these 12 companies employed 291,295 people as professionals in the United States in 2016/2017, equal to 48.3 percent of their combined U.S. labor forces. Blacks represented only 3.3 percent of these professionals and Hispanics only 5.2 percent, while Asians were 37.0 percent and whites, 52.2 percent. Among the 12 companies, only HPE is an outlier in the employment of Blacks as professionals with 6.4 percent - a far higher proportion than any of the other 11 companies. HPE is also an outlier in employing Asians as professionals, with only 15.2 percent, along with HP Inc. with 16.2 percent - one-half to one-third of the proportion at the other 10 companies. At the same time, the representation of whites as professionals at both HPE and HP Inc. is over 70 percent, far higher than any of the other companies in Table V.23. Yet Hewlett-Packard was a tech company that helped give birth to Silicon Valley. Presently, we shall provide an answer to why the employment patterns of HP and its divested successors have differed from those other tech companies included in these tables. As we shall see, it has to do with Hewlett-Packard's historical roots in the "Old Economy business model." 64

Table V.23: Comparison of the employment of professionals by race/ethnicity/gender in the U.S.-based labor forces of 12 major tech companies, 2016 or 2017

\begin{tabular}{|c|c|c|c|c|c|c|c|c|c|c|c|c|}
\hline & Amazon & Apple & Microsoft & Alphabet & Intel & HPE & Cisco & Facebook & Salesforce & HP Inc & PayPal & Uber \\
\hline \multicolumn{13}{|c|}{ Total number of the company's employees in USA } \\
\hline & 174,449 & 83,759 & 74,427 & 55,546 & 54,135 & 51,989 & 37,526 & 19,679 & 18,264 & 13,613 & 10,357 & 9,382 \\
\hline \multicolumn{13}{|c|}{ Professionals as \% of the company's employees in USA } \\
\hline & 17.4 & 32.2 & 75.0 & 69.2 & 66.8 & 65.6 & 71.0 & 74.7 & 57.2 & 53.6 & 49.2 & 55.6 \\
\hline \multicolumn{13}{|c|}{ Race/ethnicity/gender of the company's professional employees in USA } \\
\hline All U. S. professional employees & 30,433 & 27,010 & 55,829 & 38,428 & 36,160 & 34,123 & 26,661 & 14,695 & 10,448 & 7,295 & 5,096 & 5,217 \\
\hline Black or African American & 798 & 486 & 2,010 & 816 & 1,247 & 2,170 & 962 & 445 & 273 & 234 & 155 & 155 \\
\hline Hispanic & 1,052 & 1,422 & 3,074 & 1,867 & 2,277 & 2,011 & 1,250 & 783 & 408 & 475 & 247 & 247 \\
\hline Asian & 11,977 & 11,636 & 20,069 & 15,432 & 15,990 & 5,193 & 11,471 & 6,672 & 3,518 & 1,179 & 2,435 & 2,174 \\
\hline White & 15,715 & 12,973 & 29,178 & 19,295 & 15,888 & 24,221 & 12,631 & 6,244 & 5,938 & 5,282 & 2,186 & 2,444 \\
\hline Native Hawaiian or Pacific Isiander & 44 & 66 & 113 & 59 & 224 & 47 & 40 & 33 & 33 & 10 & 13 & 11 \\
\hline American Indian or Native Alaskan & 53 & 53 & 300 & 25 & 143 & 143 & 61 & 13 & 15 & 26 & 9 & 14 \\
\hline Two or more races & 794 & 374 & 1,085 & 934 & 391 & 338 & 246 & 505 & 263 & 89 & 51 & 172 \\
\hline Female & 8,124 & 6,804 & 14,295 & 9,369 & 9,866 & 11,273 & 6,932 & 4,747 & 3,428 & 2,447 & 1,735 & 1,579 \\
\hline Male & 22,309 & 20,206 & 41,534 & 29,059 & 26,294 & 22,850 & 19,729 & 9,948 & 7,020 & 4,848 & 3,361 & 3,638 \\
\hline \multicolumn{13}{|c|}{ Race/ethnicity/gender as \% of the company's professional employees in USA } \\
\hline Black or African American & 2.6 & 1.8 & 3.6 & 2.1 & 3.4 & 6.4 & 3.6 & 3.0 & 2.6 & 3.2 & 3.0 & 3.0 \\
\hline Hispanic & 3.5 & 5.3 & 5.5 & 4.9 & 6.3 & 5.9 & 4.7 & 5.3 & 3.9 & 6.5 & 4.8 & 4.7 \\
\hline Asian & 39.4 & 43.1 & 35.9 & 40.2 & 44.2 & 15.2 & 43.0 & 45.4 & 33.7 & 16.2 & 47.8 & 41.7 \\
\hline White & 51.6 & 48.0 & 52.3 & 50.2 & 43.9 & 71.0 & 47.4 & 42.5 & 56.8 & 72.4 & 42.9 & 46.8 \\
\hline Native Hawaiian or Pacific Isiander & 0.1 & 0.2 & 0.2 & 0.2 & 0.6 & 0.1 & 0.2 & 0.2 & 0.3 & 0.1 & 0.3 & 0.2 \\
\hline American Indian or Native Alaskan & 0.2 & 0.2 & 0.5 & 0.1 & 0.4 & 0.4 & 0.2 & 0.1 & 0.1 & 0.4 & 0.2 & 0.3 \\
\hline Two or more races & 2.6 & 1.4 & 1.9 & 2.4 & 1.1 & 1.0 & 0.9 & 3.4 & 2.5 & 1.2 & 1.0 & 3.3 \\
\hline \begin{tabular}{|l|} 
Female \\
\end{tabular} & 26.7 & 25.2 & 25.6 & 24.4 & 27.3 & 33.0 & 26.0 & 32.3 & 32.8 & 33.5 & 34.0 & 30.3 \\
\hline Male & 73.3 & 74.8 & 74.4 & 75.6 & 72.7 & 67.0 & 74.0 & 67.7 & 67.2 & 66.5 & 66.0 & 69.7 \\
\hline
\end{tabular}

Source: Company EEO-1 reports to the U.S. Equal Opportunity Employment Commission.

At Intel, Facebook, and PayPal, Asians had higher shares of professional employment than whites. The overrepresentation of Asians in tech companies in the San Francisco Bay Area is corroborated by a study, "The Illusion of Asian Success: Scant Progress for Minorities in Cracking the Glass Ceiling from 2007-2015," carried out by two former Cisco executives, Buck Gee and Denise Peck. They used publicly available aggregate EEO-1 data on "manufacturing" and "information" companies in the San Francisco Bay Area as proxies for tech-company data. Writing for Ascend, a foundation that calls itself "the largest non-profit Pan-Asian organization for business professionals in North America," 65 Gee and Peck entitled their report "The Illusion of Asian Success" because, relative to Asian over-representation among professionals, Asians

${ }^{64}$ Lazonick, Sustainable Prosperity.

${ }^{65}$ Ascend: Pan-Asian Leaders, "Who We Are," at https://www.ascendleadership.org/. 
were less over-represented going up the organizational hierarchy to "managers" (EEO-1 classification First/Mid Officials \& Managers) and "executives" (EEO-1 classification Executive/SR Officials \& Managers).

As shown in Table V.24, Asians' share of "professionals" employment in manufacturing and information companies in the Bay Area rose from 37.0 percent in 2007 to 41.2 percent in 2015, while whites' share fell from 52.1 percent to 47.0 percent. Meanwhile, Hispanics' share stayed constant at 5.7 percent, while Blacks' share fell from 3.6 percent to 3.1 percent. Asian men made the largest gains, although Asian women also increased their share and were overrepresented throughout the period. The underlying data show that there were persistently more Black female professionals than Black male professionals.

Table V.24: Representation by race/ethnicity/gender among employees in manufacturing and information companies in the San Francisco Bay Area, 2007-2015

\begin{tabular}{|c|c|c|c|c|c|c|c|c|c|}
\hline & 2007 & 2008 & 2009 & 2010 & 2011 & 2012 & 2013 & 2014 & 2015 \\
\hline \multicolumn{10}{|c|}{ Number of employees } \\
\hline Professionals & 357,107 & 375,781 & 365,104 & 369,809 & 392,510 & 411,604 & 439,175 & 455,477 & 482,459 \\
\hline Managers & 145,326 & 150,074 & 140,293 & 143,084 & 149,025 & 155,568 & 159,405 & 169,986 & 180,158 \\
\hline Executives & 28,755 & 29,097 & 26,941 & 27,507 & 28,462 & 29,514 & 33,223 & 35,006 & 34,647 \\
\hline \multicolumn{10}{|c|}{$\%$ share of professionals } \\
\hline Blacks & 3.6 & 3.5 & 3.6 & 3.4 & 3.3 & 3.3 & 3.2 & 3.2 & 3.1 \\
\hline Hispanics & 5.7 & 5.6 & 5.6 & 5.5 & 5.6 & 5.6 & 5.7 & 5.8 & 5.7 \\
\hline Asians & 37.0 & 37.9 & 38.0 & 38.4 & 38.8 & 39.3 & 39.0 & 40.4 & 41.2 \\
\hline Whites & 52.1 & 51.3 & 51.0 & 50.6 & 50.1 & 49.3 & 49.3 & 47.8 & 47.0 \\
\hline Other & 1.6 & 1.7 & 1.8 & 2.0 & 2.3 & 2.6 & 2.7 & 2.9 & 3.0 \\
\hline \multicolumn{10}{|c|}{$\%$ share of managers } \\
\hline Blacks & 4.3 & 4.2 & 4.1 & 3.9 & 3.8 & 3.7 & 3.6 & 3.5 & 3.5 \\
\hline Hispanics & 8.1 & 8.0 & 8.0 & 7.9 & 7.8 & 7.9 & 7.7 & 7.8 & 7.8 \\
\hline Asians & 22.1 & 22.9 & 23.8 & 24.5 & 25.0 & 25.8 & 26.1 & 26.9 & 27.7 \\
\hline Whites & 63.9 & 63.3 & 62.5 & 61.8 & 61.5 & 60.4 & 60.1 & 59.1 & 58.0 \\
\hline Other & 1.5 & 1.5 & 1.6 & 1.8 & 2.0 & 2.3 & 2.5 & 2.7 & 2.9 \\
\hline \multicolumn{10}{|c|}{$\%$ share of executives } \\
\hline Blacks & 2.1 & 1.8 & 1.8 & 1.9 & 1.6 & 1.6 & 1.7 & 1.7 & 1.7 \\
\hline Hispanics & 4.7 & 3.7 & 3.8 & 3.9 & 3.7 & 4.7 & 3.9 & 4.1 & 4.2 \\
\hline Asians & 15.4 & 16.6 & 16.4 & 16.9 & 17.7 & 17.5 & 20.1 & 21.0 & 20.0 \\
\hline Whites & 76.6 & 76.6 & 76.6 & 75.9 & 75.6 & 74.7 & 72.7 & 71.4 & 72.1 \\
\hline Other & 1.3 & 1.2 & 1.3 & 1.4 & 1.4 & 1.5 & 1.7 & 1.9 & 2.0 \\
\hline
\end{tabular}

Source: Buck Gee and Denise Peck, "The Illusion of Asian Success: Scant Progress for Minorities in Cracking the Glass Ceiling from 2007-2015," Ascend: Pan-Asian Leaders, at

https://c.ymcdn.com/sites/www.ascendleadership.org/resource/resmgr/research/TheIllusionofAsianSucces s.pdf.

The trends were much the same among managers and executives, with Asians increasing their representation over the nine-year period, while Blacks, Hispanics, and whites lost share. Indeed, there were slightly fewer Black managers in 2015 than in 2007, despite the fact that the total number of managerial positions in the San Francisco Bay Area manufacturing and information companies increased by 24 percent over these nine years. Even at the executive level, where the gap between the proportional representation of whites and the other groups remained greatest, Asians were vastly over-represented while Blacks and Hispanics were vastly under-represented. Over time, Asians have been closing the proportional-representation gap with whites, while the representation of Blacks has continued to be dismal. 


\section{Equal employment opportunity in the New Economy?}

Thus far in reporting the findings of our Fifty Years After project, our analysis of what has happened to Black employment over the past half century has documented the importance of manufacturing employment to the upward socioeconomic mobility of Blacks in the 1960s and 1970s and the devastating impact of rationalization - the permanent elimination of blue-collar employment — on their socioeconomic mobility in the 1980s and beyond. The upward mobility of Blacks in the earlier decades was based on OEBM. The founding of the EEOC in 1965 assumed the existence of OEBM with its characteristic "career-with-one-company" (CWOC) employment relations. OEBM enabled Blacks to advance over the course of their working lives by gaining access to stable employment within companies, and it was through these internal employment structures that Blacks could gain the advantages of affirmative action.

In the 1960s and 1970s, that upward mobility occurred on the basis of internal employment structures within blue-collar occupations for which no more than a high-school education was required. Access to unionized semiskilled jobs still gave working people, including Blacks, the large measure of employment stability as well as rising wages and benefits characteristic of the lower levels of a "middle class." The next stage in this process of upward socioeconomic mobility should have been - and in a nation as prosperous as the United States could have been - the entry of the offspring of the new blue-collar middle class into white-collar occupations requiring college educations. The data that we have presented above on the underrepresentation of Blacks among STEM workers is a stark manifestation of the short-circuiting of intergenerational upward mobility.

What explains the enormous presence of Asian Americans and the glaring absence of African Americans in well-paid employment in the New Economy? A cogent answer to this question requires an understanding of the institutional conditions that determine the availability of qualified Asians and Blacks to fill these employment opportunities as well as the access of these qualified people to the employment opportunities that are available. Our analysis of the racial determinants of STEM employment focuses on a) stark differences among racial and ethnic groups in educational performance relevant to accessing STEM occupations, b) the decline in the implementation of affirmative-action legislation from the early 1980s, c) changes in U.S. immigration policy that favored the entry of well-educated Asians, especially with the passage of the Immigration Act of 1990, and d) consequent social barriers that qualified Blacks have faced relative to Asians in accessing tech employment as a result of a combination of statistical discrimination and their absence from relevant social networks.

\section{a) Rationalization and the racialization of education performance}

In Working Paper \#2, we presented the 2016 levels of educational attainment for persons 25 or older by race and Hispanic ethnicity showing the degree to which Blacks have lagged whites. Briefly, a higher proportion of Blacks than whites has only a high-school degree, 31 percent compared to 26 percent, and only some years of college without getting a degree, 21 percent compared to 16 percent. Roughly, the same proportion of Blacks and whites has an associate's degree, 11 versus 12 percent, but Blacks lag whites noticeably in the proportion with a bachelor's degree or more, 29 percent compared to 39 percent. Yet, 40 percent of Blacks have an associate's or college degree. 
It is critical, however, to start searching for answers to the persistent lack of equal opportunity for Blacks in the K-12 grades of school. A 2018 report, "Public Education Funding Inequity in an Era of Increasing Concentration of Poverty and Resegregation," by the United States Commission on Civil Rights, ${ }^{66}$ begins:

In 1954, the Supreme Court decreed in Brown v. Board of Education that public education "is a right which must be made available to all on equal terms," 67 yet all across the United States (U.S.), there are many millions of students who are unable to access a quality public education due to inequities in public education finance. With insufficient financial resources, our nation's public schools generally struggle to provide a quality education on equal terms and evidence is concrete that "the U.S. educational system is one of the most unequal in the industrialized world, and students routinely receive dramatically different learning opportunities based on their social status." 68

Below we document the stark achievement gap between Black and white high-school students on PISA, a well-recognized international standardized test. As background for these results, we review extremely briefly what is known about the trends in the Black-white achievement gap and, more generally, how racial and income segregation as well as income inequality are associated with the gap. ${ }^{69}$ This brief discussion serves two purposes. First, as we argue below, disparities in achievement and educational opportunities are undoubtedly part of the explanation for the disappointing record of Black employment in the technology sector. Second, our story of employment gains for Blacks in the 1960s and 1970s and the stalling of those gains in later decades parallels the time path of the racial gap in educational achievement and are connected in two ways. Better employment generates the income for greater local school resources as well as housing mobility, while disparities in school resources and racial segregation are associated with racial achievement gaps.

On average, resources available to students in predominantly Black schools are significantly fewer than for students going to predominantly white schools because predominantly Black schools are on average in poorer school districts and because of racial segregation itself. Within school districts in the United States, schools are highly segregated by race and income. ${ }^{70}$ Segregation by income has increased substantially and is an important predictor of racial achievement gaps. ${ }^{71}$ One specific aspect of racial socioeconomic segregation, the average

${ }^{66}$ U.S. Commission on Civil Rights, "Public Education Funding Inequity in an Era of Increasing Concentration of Poverty and Resegregation," Briefing Report, January 2018, at https://www.usccr.gov/pubs/2018/2018-01-10-Education-Inequity.pdf.

${ }^{67}$ The citation of the quote in the Briefing Report, p. 3, is Brown v. Board of Education of Topeka, 347 U.S. 483,493 (1954).

${ }^{68}$ The citation of the quote in the Briefing Report, p. 3, is Linda Darling Hammond, "Unequal Opportunity: Race and Education," Brookings Institution, March 1, 1998, at https://www.brookings.edu/articles/unequal-opportunity-race-andeducation/.

${ }^{69}$ Causes of the manifest gap in school achievement between Blacks and whites have been studied extensively for decades, and the debate is very politically charged. Here we only summarize some of the latest and, in our judgement, most carefully researched empirical findings, drawing heavily on the work of Sean Reardon and his colleagues at the Center for Education Policy Analysis at Stanford University, using a curated national data archive. See https://cepa.stanford.edu/seda/overview.

70 "The average black student, for example, attends a school that is 50 percent black (and 29 percent white), whereas blacks only comprise 16 percent of all public-school enrollment (and whites 54 percent)." Jonathan Rothwell, "Housing Costs, Zoning, and Access to High Scoring Schools," Metropolitan Policy Program Report, Brookings Institution, April 2012, p. 9, at

https:/www.brookings.edu/research/housing-costs-zoning-and-access-to-high-scoring-schools/.

71 Sean Reardon, "The Widening Income Achievement Gap,” Educational Leadership, 70, 8, 2013: 10-16 
poverty rate in schools which Blacks attend versus schools which whites attend, is a very strong predictor of Black-white achievement gaps. ${ }^{72}$

Blacks are clustered in poorer performing schools. The average Black student attends a school at the $37^{\text {th }}$ percentile for test score results. The average white student attends a school at the $60^{\text {th }}$ percentile and the average Asian at the $63{ }^{\text {rd }} .{ }^{73}$ Considering the trends from the period of the civilrights legislation, Black-white achievement gaps in math and reading lessened in the 1970s and 1980 s. $^{74}$ The gap increased in the 1990s and then decreased after $1999 .{ }^{75}$ Research has also shown that the experiences of Blacks versus whites during their time going through K-12 exacerbates the disparities in achievement. The gap is smallest when children start school in kindergarten but then grows, particularly in elementary school. ${ }^{76}$ Research indicates that the degree of racial and socioeconomic segregation explains a significant portion of the variation in racial achievement gaps. The research is less capable, however, of giving a clear answer on the contributions among separate possible channels through which segregation affects the gaps, why the gaps have changed over time, or why they increase as a child progresses through school.

Racial and income segregation affects the amount of school resources available to white versus Black students, and such segregation is associated with differences in family resources and a host of neighborhood factors that may also affect school achievement. All of these influences are closely intertwined, and the independent influences cannot be pulled apart with the data available. Sean Reardon, Demetra Kalogrides, and Kenneth Shores use extensive national data on nearly all school districts and metropolitan areas in the United States to document the enormous variation in achievement gaps across school districts and metropolitan areas, from no gaps to very substantial gaps. ${ }^{77}$ Recognizing that identifying separate causal factors behind the effect of racial segregation is not possible, they "set out to answer a different (and simpler) set of questions: 'to what extent do racial achievement gaps vary across the U.S., and what are the strongest correlates of these gaps?"”

The analyses here confirm that family resource differences and segregation patterns are strongly associated with racial achievement gaps in school districts and metropolitan areas. In all of our analyses, racial socioeconomic disparities and segregation patterns are consistently the strongest predictors of racial achievement gaps. ${ }^{78}$

The importance of household socioeconomic resources to educational performance is the most robust finding of this research, but variations in resources available to schools matter as well.

\footnotetext{
72. Sean Reardon, "School Segregation and Racial Academic Achievement Gaps," Russell Sage Foundation Journal of the Social Sciences, 2, 5, 2016: 34-57.

${ }^{73}$ Rothwell, "Housing Costs," p. 8.

${ }^{74}$ Sean Reardon, Joseph Robinson, and Ericka S. Weathers, "Patterns and Trends in Racial/Ethnic and Socioeconomic Academic Achievement Gaps," in Helen A. Ladd and Margaret E. Goertz, eds., Handbook of Research in Education Finance and Policy, Routledge, 2014: 491-509. Reardon et al. use data from the National Assessment of Educational Progress (NAEP).

${ }^{75}$ Although we cannot prove causation from these time trends in achievement gaps, they are consistent with the time path of employment gains and the stalling of those gains for Blacks that we have documented in our project.

${ }^{76}$ Reardon et al., "Patterns and Trends."

${ }^{77}$ Sean Reardon, Demetra Kalogrides, and Kenneth Shores, "The Geography of Racial/Ethnic Test Score Gaps, Stanford University Center for Education Policy," American Journal of Sociology, 124, 4, 2019: 1164-1221.

${ }^{78}$ In another paper, Reardon explains the measure of racial socioeconomic disparities and segregation and its effect as follows: "the disparity in average school poverty rates between white and black students' schools...is consistently the single most powerful correlate of achievement gaps." Reardon, "School Segregation," p. 35.
} 
Racial segregation has an impact on the level of school resources beyond its direct effect on household socioeconomic resources available to districts and schools. Weathers and Sosina report that more racial segregation is associated with larger racial disparities in school revenue, net of racial socioeconomic segregation (measured by the extent of child poverty). ${ }^{79}$

When one looks at school districts that are either predominantly Black or predominantly white, the disparity in resources is more marked. EdBuild has compiled statistics from the 2015-16 school year on the resources available to districts that are greater than 75 percent white compared to districts that are 75 percent Black. ${ }^{80}$ Over half of U.S. students go to schools in very racially segregated school districts, 27 percent in districts that are more than 75 percent Black, and 26 percent in districts that are more than 75 percent white. The per pupil spending in predominantly Black school districts is $\$ 2,226$ less than the per pupil spending in predominantly white school districts, $\$ 11,682$ compared to $\$ 13,908$. The national average is $\$ 13,118 .{ }^{81}$

While resources are clearly uneven across segregated Black and white districts, until recently research was not conclusive on the importance of resource disparities in explaining achievement gaps. Several recent studies have established, however, that more school resources lead to higher achievement levels; that is, "money matters" in educational outcomes. ${ }^{82}$ This finding suggests that the reversal of employment gains for Blacks that we have documented is related to racial achievement gaps through its effect on disparities in school and household resources.

The inferior quality of education that Blacks receive in the United States shows up in the Performance for International Student Assessment (PISA) scores that the Organisation for Economic Cooperation and Development (OECD) has administered internationally to 15-yearold students since $2000 .{ }^{83}$ The first assessment, carried out in 2000 , was on reading, the second in 2003 on mathematics, and the third in 2006 on science. New rounds of reading tests were done in 2003 and mathematics tests in 2006, and since 2009 all three types of assessments have been done every three years. In addition, in 2012 OECD carried out a problem-solving test and in 2015 collaborative problem-solving and financial literacy tests. For the United States, the results have been reported by race, ethnicity, and gender, using the same demographic classifications as the EEO-1 diversity reports, discussed above. The results of the reading, mathematics, and science assessments through 2018, by race and ethnicity are compiled in Table V.25.

\footnotetext{
${ }^{79}$ Ericka S. Weathers and Victoria E. Sosina, "Separate Remains Unequal: Contemporary Segregation and Racial Disparities in School District Revenue," Stanford University Center for Education Policy, Working Paper No. 19-02, March 2019.

${ }^{80}$ EdBuild, "Nonwhite school districts get $\$ 23$ billion less than white districts despite serving the same number of students," 23 Billion, at https://edbuild.org/content/23-billion. The methods and data used are presented at https://edbuild.org/content/23billion/methodology EdBuild is a non-profit organization working on inequitable funding across U.S. school districts.

81 These numbers and those in the previous sentence are from EdBuild, "23 Million."

82 Julien Lafortune, Jesse Rothstein, and Diane Whitmore Schanzenbach, "School Finance Reform and the Distribution of Student Achievement,” American Economic Journal: Applied Economics, 10, 2, 2018: 1-26; C. Kirabo Jackson, Rucker C. Johnson, and Claudia Persico, "The Effects of School Spending on Educational and Economic Outcomes: Evidence from School Finance Reforms," Quarterly Journal of Economics, 131, 1, 2016: 157-218; C. Kirabo Jackson, "Does School Spending Matter? The New Literature on An Old Question," National Bureau of Economic Research, Working Paper 25368, 2018, at http://www.nber.org/papers/w25368.

${ }^{83}$ See National Center for Education Statistics, "Program for International Student Assessment (PISA)," at https://nces.ed.gov/surveys/pisa/
} 
Table V.25: U.S. Performance for International Assessment (PISA) mean scores, by race and ethnicity and compared with the OECD average, 2000-2018

\begin{tabular}{|c|c|c|c|c|c|c|c|c|c|c|c|c|c|c|}
\hline \multirow{3}{*}{\begin{tabular}{|l} 
READING \\
White \\
\end{tabular}} & \multicolumn{2}{|c|}{2000} & \multicolumn{2}{|c|}{2003} & \multirow{2}{*}{\multicolumn{2}{|c|}{\begin{tabular}{|c|}
2006 \\
Not administered \\
\end{tabular}}} & \multicolumn{2}{|c|}{2009} & \multicolumn{2}{|c|}{2012} & \multicolumn{2}{|c|}{2015} & \multicolumn{2}{|c|}{2018} \\
\hline & Mean & s.e & Mean & s.e & & & Mean & s.e & Mean & s.e & Mean & s.e & Mean & s.e \\
\hline & 538 & 5.1 & 525 & 2.6 & & & 525 & 3.8 & 519 & 4.1 & 526 & 3.3 & 531 & 3.8 \\
\hline Black & 445 & 8.2 & 430 & 5.6 & & & 441 & 7.2 & 443 & 8.3 & 443 & 5.4 & 448 & 7.1 \\
\hline Hispanic & 449 & 7.6 & 453 & 5.9 & & & 466 & 4.3 & 478 & 4.5 & 478 & 5.7 & 481 & 5.7 \\
\hline Asian & 546 & 15.8 & 513 & 9.2 & & & 541 & 9.4 & 550 & 8.1 & 527 & 13.3 & 556 & 9.0 \\
\hline Multiracial & na & na & 515 & 7.3 & & & 502 & 6.4 & 517 & 7.6 & 498 & 7.1 & 501 & 5.7 \\
\hline U.S. Average & 504 & 7.0 & 495 & 3.2 & & & 500 & 3.7 & 498 & 3.7 & 497 & 3.4 & 505 & 3.6 \\
\hline OECD Average & 492 & 0.7 & 494 & 0.6 & & & 493 & 0.5 & 496 & 0.5 & 493 & 0.5 & 487 & 0.4 \\
\hline MATHEMATICS & Not adm & nistered & Mean & s.e & Mean & s.e & Mean & s.e & Mean & s.e & Mean & s.e & Mean & s.e \\
\hline White & & & 512 & 2.5 & 502 & 3.1 & 515 & 3.9 & 506 & 3.7 & 499 & 2.8 & 503 & 3.4 \\
\hline Black & & & 417 & 5.1 & 404 & 8.9 & 423 & 6.6 & 421 & 6.2 & 419 & 4.7 & 419 & 5.8 \\
\hline Hispanic & & & 443 & 5.1 & 436 & 4.5 & 453 & 3.8 & 455 & 4.8 & 446 & 5.2 & 452 & 4.6 \\
\hline Asian & & & 506 & 9.8 & 494 & 8.7 & 524 & 9.6 & 549 & 9.0 & 498 & 10.1 & 539 & 7.9 \\
\hline Multiracial & & & 502 & 6.4 & 482 & 7.6 & 487 & 6.4 & 492 & 7.4 & 475 & 7.0 & 474 & 5.8 \\
\hline U.S. Average & & & 483 & 2.9 & 474 & 4.0 & 487 & 3.6 & 481 & 3.6 & 470 & 3.2 & 478 & 3.2 \\
\hline OECD Average & & & 499 & 0.6 & 494 & 0.5 & 495 & 0.5 & 494 & 0.5 & 490 & 0.4 & 489 & 0.4 \\
\hline SCIENCE & Not $a d m$ & istered & Not adn & istered & Mean & s.e & Mean & s.e & Mean & s.e & Mean & s.e & Mean & s.e \\
\hline White & & & & & 523 & 3.0 & 532 & 4.0 & 528 & 3.7 & 531 & 2.8 & 529 & 3.4 \\
\hline Black & & & & & 409 & 8.8 & 435 & 7.2 & 439 & 6.8 & 433 & 4.9 & 440 & 6.3 \\
\hline Hispanic & & & & & 439 & 4.7 & 464 & 3.8 & 462 & 4.7 & 470 & 4.8 & 478 & 5.1 \\
\hline Asian & & & & & 499 & 9.7 & 536 & 9.7 & 546 & 8.6 & 525 & 12.0 & 551 & 9.4 \\
\hline Multiracial & & & & & 501 & 8.0 & 503 & 7.6 & 511 & 7.8 & 503 & 6.4 & 502 & 6.1 \\
\hline U.S. Average & & & & & 489 & 4.2 & 502 & 3.6 & 497 & 3.8 & 496 & 3.2 & 502 & 3.3 \\
\hline OECD Average & & & & & 498 & 0.5 & 501 & 0.5 & 501 & 0.5 & 493 & 0.4 & 489 & 0.4 \\
\hline
\end{tabular}

Note: The mean scores (and standard errors) on the 2012 problem-solving test were white 532 (4.2), black 436 (7.1), Hispanic 486 (5.7), Asian 564 (10.9), multiracial 523 (8.7); on the 2015 collaborative problem-solving test were white 550 (3.5), black 471 (6.3), Hispanic 497 (5.1), Asian 559 (14.1), multiracial 523 (8.1); and on the financialliteracy test were white 524 (3.7), black 422 (6.4), Hispanic 460 (5.8), Asian 525 (13.7), multiracial 494 (7.5).

Source: National Center for Education Statistics, "Program for International Student Assessment (PISA)," PISA Data Explorer, at https://nces.ed.gov/surveys/international/ide/.

In PISA 2000, the reading performance of U.S. students was above the average for the 29 participating OECD nations, with the United States ranked 13 ${ }^{\text {th }}$. In PISA 2018, the reading performance of U.S. students was still above the OECD average, with the United States now ranked $9^{\text {th }}$ out of 35 OECD nations. In all cases, in the United States, Blacks and Hispanics did significantly worse on the reading assessments than whites and Asians. In the PISA 2018 reading rankings, U.S. Asians had a score of 556 that would have placed them-as a hypothetical nation - ahead of the $1^{\text {st }}$ place OECD country, Estonia (523), and one point ahead of China (555), the highest scoring among all countries which reported PISA scores. With a score of 526, U.S. whites would have been tied with Finland for $2^{\text {nd }}$, while with a score of 443 U.S. Blacks would have ranked $33^{\text {rd }}$, ahead of only Turkey (428) and Mexico (423) among OECD nations.

In PISA 2003, the mathematics performance of U.S. students was below the OECD average, with the United States ranked $25^{\text {th }}$ out of 30 OECD countries. In PISA 2018, the mathematics performance of U.S. students was still below the OECD average, with the United States ranked $31^{\text {st }}$ out of 35 OECD nations and whites and Asians performing far better than Blacks and Hispanics. In the PISA 2018 mathematics rankings, U.S. whites had a score of 503, which would have placed them as a hypothetical nation $12^{\text {th }}$ among OECD countries, and U.S. Asians a score of 539, which would have elevated them to $1^{\text {st }}$ place. The score for U.S. Blacks of 419 would have ranked them $34^{\text {th }}$, ahead of only Chile (417) and Mexico (409) among OECD nations. 
In PISA 2006, the science performance of U.S. students was also below the OECD average, with the United States ranked $24^{\text {th }}$ of 35 OECD countries. In PISA 2018, however, the science performance of U.S. students was now above the OECD average, with the United States ranked $13^{\text {th }}$ of 35 OECD countries. As in reading and mathematics, for the United States, the science scores of whites and Asians were far better than those of Blacks and Hispanics. In the PISA 2018 science rankings, U.S. whites had a score of 529, which would have tied them for $1^{\text {st }}$ with Japan among OECD nations. U.S. Asians had a score of 551, which would have placed them tied with Singapore for $2^{\text {nd }}$ among all nations, while U.S. Blacks had a score of 440, which would have ranked them $33^{\text {rd }}$, ahead of only Mexico (419) among OECD nations.

The U.S. K-12 system has left Blacks as a group ill-prepared for high-level STEM occupations, whereas just the opposite is the case for Asians and whites. Most studies of the problem, including the 2018 report of the U.S. Commission on Civil Rights, lay the blame on continued patterns of residential segregation of Blacks and Hispanics combined with the underfunding both across and within school districts of the public schools that Blacks and Hispanics attend. ${ }^{84}$

Our findings, however, point to the more fundamental role of the transformation of employment relations since the 1980s in limiting the intergenerational socioeconomic mobility of Blacks. First, the rationalization of employment relations eliminated blue-collar manufacturing employment that had enabled high-school educated Blacks, as well as whites, to attain a middleclass standard of living. Second, there was the marketization of employment relations that eliminated career-with-one-company employment in white-collar occupations, including those in STEM fields that require advanced education. And third, there was globalization of the high-tech labor force that gave U.S. companies access to highly qualified STEM labor, especially from the emerging Asian economies, India, China, South Korea, and Taiwan foremost among them. Deficiencies in Black education did not create these employment outcomes. Rather, we argue, the lack of commitment of U.S. business enterprises and government agencies to create new employment opportunities for Blacks as the old opportunities disappeared resulted in a lack of social commitment to provide Blacks with the upgraded education and ongoing career support that the new middle-class employment opportunities require.

\section{b) Marketization and the undermining of affirmative action}

In the 1960s and 1970s, with unionized blue-collar employment in strong demand, the implementation of affirmative action under the EEOC supported the upward mobility of Blacks within the ranks of blue-collar manufacturing. During this period, also encouraged by affirmative action, many large U.S. corporations also sought to integrate Blacks into their college-educated white-collar labor forces on a significant but much more limited scale. A case in point for the implementation of affirmative action in the decades immediately following the creation of the EEOC is Hewlett-Packard (HP), a company that until the late 1990s epitomized the provision of a career with one company under OEBM - a system of employment that in 1995 founder David Packard extolled in his best-selling book, The HP Way. ${ }^{85}$ Moreover, founded in Palo Alto,

\footnotetext{
${ }^{84}$ See Ary Spatig-Amerikaner, "Unequal Education: Federal Loophole Enables Lower Spending on Students of Color," Center for American Progress, August 12, 2012, at https://www.americanprogress.org/issues/education-k12/reports/2012/08/22/29002/unequal-education/.

85 David Packard, The HP Way: How Bill Hewlett and I Built Our Company, HarperBusiness, 1995.
} 
California in 1939 by Stanford University engineering graduates, HP was located in the heart of the industrial district that from the 1970s became known as Silicon Valley.

In its 1957 Annual Report, when HP had just listed on the stock market, the company's management wrote: "It is Hewlett-Packard's policy to select the best possible people and give them real authority. This delegation, plus a manufacturing organization built up of small groups each producing a single kind or class of instruments, has made possible quality, low cost and maximum output." 86 The following year, HP reported a growth in full-time personnel from 1,440 to 1,700 , who "continued to enjoy the benefits and conditions offered by Hewlett-Packard under its personnel philosophy of informality, friendliness, and sharing financially in the Company's success." 87 The 1959 Report stated that "Hewlett-Packard today is a Company of over 2,000 youthful, energetic people developed during 20 years of careful selection, training, and meritbased advancement." 88 In its 1960 Report, with 3,500 employees, HP said that it had "accelerated the training of its own sales force to keep pace with the rapid development of new products. To provide field engineers with a thorough technical knowledge of these new devices, the company increased the number and scope of its factory sales seminars." 89

In short, HP was a high-tech company that, like other Old Economy firms, viewed "its fine engineering group" to be "one of its most valuable assets." ${ }^{90}$ It is significant, therefore, that in its 1966 Report, the year in which the EEOC was launched, HP's top executives, David Packard as Board Chairman and William Hewlett as President, informed the company's shareholders: "We have asked all our management people to continue to place emphasis on employment and advancement of people from minority groups." 91 In 1968, the company reported that "the appointment of a full-time Equal Opportunities Manager enhanced our corporate-wide efforts to provide worthwhile jobs for minorities and less advantaged groups in our society. We are accelerating these efforts particularly in the area of training, as a means of obtaining good people and contributing constructively to the solution of a critical social and economic problem." 92

In 1970, employing 16,000 people at year end, HP saw its first decline in profits since 1958, and had a net increase of employment of only 200. Restating its "commitment to broadening opportunities to minorities and less advantaged people," HP reported that "Affirmative Action programs are in effect throughout our plants and offices to assure advancement opportunities for qualified minority personnel and to assure, as well, that when we resume normal hiring, minorities will represent a fair share of our new people." 93

In its 1975 Annual Report, HP laid out "The Four Dimensions of Hewlett-Packard Responsibility." From its founding in 1939, the first three areas of responsibility were "to customers, to employees, and to the community at large. Later [in 1957], when stock ownership was extended to the public, a fourth was added - responsibility to shareholders." 94 With the

\footnotetext{
${ }^{86}$ Hewlett-Packard, Annual Report 1957, p. 8.

${ }^{87}$ Hewlett-Packard, Annual Report 1958, p. 12.

${ }^{88}$ Hewlett-Packard, Annual Report 1959, p. 15.

${ }^{89}$ Hewlett-Packard, Annual Report 1960, p. 5.

${ }^{90}$ Hewlett-Packard, Annual Report 1959, p. 8.

${ }^{91}$ Hewlett-Packard, Annual Report 1966, p. 4.

${ }^{92}$ Hewlett-Packard, Annual Report 1968, p. 5.

${ }^{93}$ Hewlett-Packard, Annual Report 1970, p. 4.

${ }^{94}$ Hewlett-Packard, Annual Report 1975, p. 4.
} 
company focusing on employees and the community, in the 1975 Report HP began documenting its "Affirmative Action Progress" in a table with the number of minorities and females employed and their percentages of the company's U.S. "managers \& supervisors," "professionals," "technicians," and "skilled" in 1970 and $1975 .{ }^{95}$ HP then continued to report these EEO-1 data in every annual report for the next 14 years, enabling us to construct Table V.26.

Table V.26: Hewlett-Packard minority and female employment in the United States, by occupational category, 1970-1989

\begin{tabular}{|c|c|c|c|c|c|c|c|c|c|c|}
\hline & \multicolumn{5}{|c|}{ Managers \& Supervisors } & \multicolumn{5}{|c|}{ Professionals } \\
\hline & Total & Minorities & $\%$ of total & Females & $\%$ of total & Total & Minorities & $\%$ of total & Females & $\%$ of total \\
\hline 1970 & 1,101 & 41 & 3.7 & 26 & 2.4 & 2,658 & 121 & 4.6 & 75 & 2.8 \\
\hline 1971 & 1,344 & 59 & 4.4 & 33 & 2.5 & 2,483 & 115 & 4.6 & 77 & 3.1 \\
\hline 1972 & 1,597 & 78 & 4.9 & 47 & 2.9 & 2,534 & 141 & 5.6 & 133 & 5.2 \\
\hline 1973 & 1,831 & 95 & 5.2 & 70 & 3.8 & 3,501 & 251 & 7.2 & 232 & 6.6 \\
\hline 1974 & 2,298 & 121 & 5.3 & 157 & 6.8 & 4,195 & 380 & 9.1 & 432 & 10.3 \\
\hline 1975 & 2,342 & 121 & 5.2 & 175 & 7.5 & 4,495 & 429 & 9.5 & 493 & 11.0 \\
\hline 1976 & 2,517 & 144 & 5.7 & 226 & 9.0 & 5,260 & 521 & 9.9 & 648 & 12.3 \\
\hline 1977 & 2,775 & 180 & 6.5 & 267 & 9.6 & 6,079 & 586 & 9.6 & 836 & 13.8 \\
\hline 1978 & 3,849 & 302 & 7.8 & 640 & 16.6 & 7,278 & 748 & 10.3 & 1,132 & 15.6 \\
\hline 1979 & 4,931 & 448 & 9.1 & 943 & 19.1 & 9,610 & 1,046 & 10.9 & 1,711 & 17.8 \\
\hline 1980 & 5,830 & 564 & 9.7 & 1,198 & 20.5 & 10,838 & 1,180 & 10.9 & 2,206 & 20.4 \\
\hline 1981 & 6,717 & 649 & 9.7 & 1,427 & 21.2 & 12,799 & 1,436 & 11.2 & 2,924 & 22.8 \\
\hline 1982 & 7,375 & 743 & 10.1 & 1,658 & 22.5 & 13,559 & 1,586 & 11.7 & 3,291 & 24.3 \\
\hline 1983 & 7,866 & 806 & 10.2 & 1,863 & 23.7 & 15,178 & 1,832 & 12.1 & 3,998 & 26.3 \\
\hline 1984 & 8,680 & 926 & 10.7 & 2,187 & 25.2 & 17,429 & 2,226 & 12.8 & 4,949 & 28.4 \\
\hline 1985 & 9,282 & 991 & 10.7 & 2,375 & 25.6 & 18,569 & 2,477 & 13.3 & 5,415 & 29.2 \\
\hline 1986 & 9,376 & 1,016 & 10.8 & 2,368 & 25.3 & 18,830 & 2,605 & 13.8 & 5,573 & 29.6 \\
\hline 1987 & 9,025 & 954 & 10.6 & 2,317 & 25.7 & 19,634 & 2,935 & 14.9 & 5,955 & 30.3 \\
\hline 1988 & 9,257 & 1,044 & 11.3 & 2,391 & 25.8 & 22,082 & 3,494 & 15.8 & 6,835 & 31.0 \\
\hline \multirow[t]{3}{*}{1989} & 9,668 & 1,100 & 11.4 & 2,543 & 26.3 & 22,733 & 3,618 & 15.9 & 6,977 & 30.7 \\
\hline & \multicolumn{5}{|c|}{ Technicians } & \multicolumn{5}{|c|}{ Skilled } \\
\hline & Total & Minorities & $\%$ of total & Females & $\%$ of total & Total & Minorities & \% of total & Females & $\%$ of total \\
\hline 1970 & 1,612 & 154 & 9.6 & 136 & 8.4 & 1,584 & 163 & 10.3 & 233 & 14.7 \\
\hline 1971 & 1,547 & 145 & 9.4 & 121 & 7.8 & 1,521 & 161 & 10.6 & 235 & 15.5 \\
\hline 1972 & 1,643 & 173 & 10.5 & 142 & 8.6 & 1,638 & 181 & 11.1 & 209 & 12.8 \\
\hline 1973 & 2,138 & 226 & 10.6 & 174 & 8.1 & 1,848 & 230 & 12.4 & 279 & 15.1 \\
\hline 1974 & 2,418 & 295 & 12.2 & 233 & 9.6 & 2,294 & 355 & 15.5 & 485 & 21.1 \\
\hline 1975 & 2,607 & 340 & 13.0 & 274 & 10.5 & 2,422 & 385 & 15.9 & 500 & 20.6 \\
\hline 1976 & 2,592 & 330 & 12.7 & 288 & 11.1 & 2,336 & 365 & 15.6 & 394 & 16.9 \\
\hline 1977 & 2,852 & 368 & 12.9 & 317 & 11.1 & 2,428 & 410 & 16.9 & 426 & 17.5 \\
\hline 1978 & 3,338 & 448 & 13.4 & 367 & 11.0 & 2,283 & 366 & 16.0 & 292 & 12.8 \\
\hline 1979 & 4,133 & 591 & 14.3 & 497 & 12.0 & 2,320 & 379 & 16.3 & 296 & 12.8 \\
\hline 1980 & 4,558 & 707 & 15.5 & 575 & 12.6 & 2,426 & 428 & 17.6 & 321 & 13.2 \\
\hline 1981 & 5,059 & 798 & 15.8 & 727 & 14.4 & 2,577 & 469 & 18.2 & 361 & 14.0 \\
\hline 1982 & 5,214 & 844 & 16.2 & 794 & 15.2 & 2,718 & 515 & 18.9 & 404 & 14.9 \\
\hline 1983 & 5,379 & 896 & 16.7 & 831 & 15.4 & 2,843 & 552 & 19.4 & 448 & 15.8 \\
\hline 1984 & 5,719 & 993 & 17.4 & 872 & 15.2 & 2,914 & 594 & 20.4 & 500 & 17.2 \\
\hline 1985 & 5,797 & 1,031 & 17.8 & 907 & 15.6 & 2,884 & 614 & 21.3 & 517 & 17.9 \\
\hline 1986 & 5,663 & 1,022 & 18.0 & 875 & 15.5 & 2,665 & 581 & 21.8 & 460 & 17.3 \\
\hline 1987 & 5,505 & 1,007 & 18.3 & 830 & 15.1 & 2,521 & 557 & 22.1 & 444 & 17.6 \\
\hline 1988 & 5,401 & 1,001 & 18.5 & 816 & 15.1 & 2,265 & 531 & 23.4 & 403 & 17.8 \\
\hline \multirow[t]{2}{*}{1989} & 5,757 & 1,118 & 19.4 & 875 & 15.2 & na & na & & na & \\
\hline & & & & & & \multicolumn{5}{|c|}{ Skilled/Semi-skilled } \\
\hline 1984 & & & & & & 15,519 & 4,446 & 28.6 & 8,264 & 53.3 \\
\hline 1989 & & & & & & 10,716 & 3,241 & 30.2 & 5,615 & 52.4 \\
\hline
\end{tabular}

Source: Hewlett-Packard Annual Reports, 1975-1989

${ }^{95}$ Ibid., p. 12. 
As Table V.26 shows, HP made significant progress in the employment of minorities and females in all occupational categories, and especially as professionals. In 1971, out of 2,483 professionals at HP in the United States, only 4.5 percent were minorities. By 1989, the number of professionals in HP's U.S.-based labor force had increased more than nine-fold, while the number of minority professionals had grown by more than 31 times, now representing 15.9 percent of HP's U.S. professionals. HP's affirmative-action agenda in the 1970s and 1980s opened up employment opportunities for highly educated minorities.

While useful, the data in Table V.26 are from ideal. We do not know what type of minorities HP employed in the 1970s and 1980s. Specifically, to what extent were these employees Black? Access to HP's actual EEO-1 filings for these decades would permit a definitive answer to this question, but, in their absence, there are reasons to believe African Americans were wellrepresented among HP's minority employees in the 1970s and 1980s. During those decades, as shown in Table V.27, Asians were only a small, albeit rising, percentage of the U.S. population. We can assume, therefore, that a significant number of Blacks were among the increased number of minorities employed as professionals at HP in the 1970s and 1980s.

Table V.27: People of Asian birth or ancestry as percentage of U.S. population, 1860-2020

\begin{tabular}{|c|c|c|c|}
\hline & Total population & \multicolumn{1}{c|}{ Asians } & \% Asian \\
\hline 1860 & $31,443,321$ & 34,933 & 0.11 \\
\hline 1870 & $38,558,371$ & 63,254 & 0.16 \\
\hline 1880 & $50,189,209$ & 105,613 & 0.21 \\
\hline 1890 & $62,979,766$ & 109,527 & 0.17 \\
\hline 1900 & $76,212,168$ & 114,189 & 0.15 \\
\hline 1910 & $92,228,496$ & 146,863 & 0.16 \\
\hline 1920 & $106,021,537$ & 182,137 & 0.17 \\
\hline 1930 & $123,202,624$ & 264,766 & 0.21 \\
\hline 1940 & $132,164,569$ & 254,918 & 0.19 \\
\hline 1950 & $151,325,798$ & 321,033 & 0.21 \\
\hline 1960 & $179,323,175$ & 980,337 & 0.55 \\
\hline 1970 & $203,211,926$ & $1,538,721$ & 0.76 \\
\hline 1980 & $226,545,805$ & $3,500,439$ & 1.55 \\
\hline 1990 & $248,709,873$ & $6,908,638$ & 2.78 \\
\hline 2000 & $281,421,906$ & $11,896,828$ & 4.23 \\
\hline 2010 & $308,745,538$ & $17,320,856$ & 5.61 \\
\hline 2020 & $331,449,281$ & $24,009,902$ & 7.24 \\
\hline
\end{tabular}

Note: 2000, 2010, and 2020 data are for people reported as Asian alone or as Asian and one or more other race or ethnicity. The number of people reported as Asian alone were $10,242,998$, in 2000 ( 3.6 percent of the total), 14,674,252 ( 4.8 percent) in 2010 , and 19,890,050 (6.0 percent) in 2020.

Sources: Campbell Gibson and Kay Jung, "Historical Census Statistics on the ForeignBorn Population of the United States: 1850 to 2000," Population Division, U.S. Census Bureau, Working Paper No. 81, February 2006, at https://www.census.gov/population/www/documentation/twps0081/twps0081.h tml; Elizabeth M. Hoeffel, Sonya Rastogi, Myoung Ouk Kim, and Hasan Shahid, "The Asian Population: 2010," 2010 Census Briefs, U.S. Census Bureau, March 2012, at https://www.census.gov/prod/cen2010/briefs/c2010br11.pdf; U.S. Census Bureau, "Decennial Census, 2020, P2: Hispanic or Latino or Not Hispanic or Latino by Race," at https://data.census.gov/cedsci/table? $\mathrm{q}=\& \mathrm{y}=2020 \& \mathrm{~d}=\mathrm{DEC} \% 20$ Redistricting $\% 2$ 0Data\%20\%28PL\%2094-171\%29\&tid=DECENNIALPL2020.P1. 
Moreover, there is strong evidence that HP's affirmative-action legacy in providing employment as professionals in the 1970s and 1980s persisted during the following decades, despite organizational changes in HP's business model that, as implemented in most other leading tech companies, were far less favorable to the employment of Blacks as professionals. Recall from Table V.23 that, at 6.4 percent, in 2016 the proportion of Blacks among professionals at Hewlett Packard Enterprise (HPE), the main successor to HP, was far higher-typically double - the proportion at other major tech companies for which we have EEO-1 data for 2016 or 2017.

As Lazonick has shown elsewhere, by the 2000s HP had shed OEBM in favor of NEBM, and, in the process jettisoning "The HP Way," had ceased to be a company defined by the provision of career employment to its personnel. ${ }^{96}$ Notwithstanding this organizational transition, it makes sense to postulate that the relative success of Blacks as professionals at HPE in 2016 was in large part due to the legacy of the recruitment, training, and promotion of Blacks under HP's proactive affirmative-action policies in the 1970s and 1980s - decades during which CWOC was solidly in place. The presence of Blacks in higher-level positions at HP at the end of the 1980s appears to have favored the continued recruitment and retention of Blacks as professionals over a quarter of a century later. In 2016, Blacks as professionals at HPE remained under-represented compared with their share of the U.S. population, but they were far better represented at HPE, with its OEBM roots, than, as we have seen, at other companies that grew from startups to dominant corporations on the basis of NEBM.

Corroboration of this finding that affirmative action under the CWOC employment relations that characterized OEBM in the 1970s and 1980s had a salutary impact on the employment of Blacks as professionals at tech companies is found in the data on IBM's diversity employment from 1996 to 2008 that we presented earlier in Table V.8. While IBM did not provide data comparable to HP's on the progress of minorities at the company in the 1970s and 1980s, it did make explicit reference to its concern with equal employment opportunity, beginning with its 1972 Annual Report. As stated in a section of the Report on "IBM and Society": "IBM has made considerable progress in promoting minority employees into positions of greater responsibility. There are now more than 700 managers from minority groups, including managers of three IBM plants." 97

In the 1974 Report, under the heading "Affirmative Action," IBM stated that during the year it had increased the number of its minority employees from 9.7 percent to 10.6 percent of its U.S. labor force, including 1,100 minority managers. ${ }^{98}$ Two years later, the proportion of minority employees had grown to 11.3 percent and the number of minority managers to $1,437 .{ }^{99}$ By 1978 its minority managers numbered $1,973,{ }^{100}$ and a year later over 2,200. ${ }^{101}$ During the 1980s, IBM continued to report its progress in employing minority managers in the United States, with the number rising to 3,900 in $1986,{ }^{102}$ and 12.9 percent of all managers in $1989 .{ }^{103}$ In its 1989

\footnotetext{
96 Lazonick, Sustainable Prosperity, ch. 4.

97 IBM, Annual Report 1972, p. 19.

98 IBM, Annual Report 1974, p. 18.

99 IBM, Annual Report 1976, p. 27.

${ }^{100}$ IBM, Annual Report 1978, p. 35. In its 1978 Report, IBM also mentioned its efforts to purchase goods and services from minority-owned suppliers, increasing "from 7 in 1968 to more than 420 companies doing more than \$35 million worth of business with IBM in 1978." Ibid.

${ }^{101}$ IBM, Annual Report 1979, p. 38.

102 IBM, Annual Report 1986, p. 20.

${ }^{103}$ IBM, Annual Report 1989, p. 22.
} 
Report, the company stated that minorities were now 17.4 percent of the U.S.-based labor force, up six percentage points from 13 years earlier. ${ }^{104}$

As in the case of HP, a legacy of IBM's affirmative-action policies in the 1970s and 1980s was the persistence of high shares of Blacks as professionals at the company in the following decades, even as IBM, from the early 1990s (as we recounted earlier), rid itself of its CWOC system, which it called "lifelong employment." As IBM marketized its employment relations, laying off senior employees whom it had once valued for their knowledge of the company's proprietary technology systems, and hired younger employees with the latest "open-systems technology" education and experience, the company transitioned from being the epitome of OEBM to a highly financialized version of NEBM. ${ }^{105}$ IBM has not released its EEO-1 data for recent years, but, as documented earlier in Table V.8, in 2008, IBM employed 3,347 Blacks who represented 6.8 percent of professionals in IBM's U.S. labor force, down from 7.8 percent $(5,047$ Black professionals) in 2001. These are, as we have seen, relatively high proportions for a tech company and similar to the shares of Blacks as professionals at HPE in 2016.

OEBM employment relations based on a career with one company were highly conducive to affirmative-action policies because of the commitment inherent in CWOC for training, retaining, and rewarding over decades the employees whom a company had recruited at the early stages of their careers. With affirmative action in place, OEBM companies like HP and IBM employed much larger proportions of Black employees than NEBM companies that, as a central characteristic of this business model, lacked explicit systems of career employment through which large numbers of Blacks, among others, could be recruited, trained, and retained as professionals. Even after IBM, from the early 1990s, and HP, from the late 1990s, shed CWOC, these companies apparently had many more Black role models in higher-level occupations who helped to keep the Old Economy affirmative-action policies in place.

From the early 1990s neither IBM nor HP continued to tout their commitments to affirmative action, in part because of declines in employment in the recession of 1990-91-documented in the Sharpe article discussed earlier ${ }^{106}$ (with IBM's downsizing in the early 1990s far more extreme than HP's) and in part because of the availability of large supplies of highly educated Asians to join the ranks of professionals in ICT. Trained in the latest open-systems technologies and often employed on H-1B and L-1 temporary immigration visas, this influx of young Asian talent into the U.S. high-tech labor force fit well with the marketized employment relations that characterized NEBM. These large supplies of Asian labor did not, however, simply appear because of "market forces." Rather, as we shall now outline, the growing importance of people of Asian origin in the U.S. high-tech labor force was enabled by U.S. immigration policy that began to be put in place with immigration reform in 1965 and which took a great leap forward with the Immigration Act of 1990.

\section{c) Globalization of the high-tech labor force through employment-based immigration reform}

In the 1980 s and beyond the combination of rationalization, marketization, and globalization struck a critical blow to the opportunities and aspirations for intergenerational upward mobility

\footnotetext{
104 Ibid.

105 Lazonick, Sustainable Prosperity, ch. 4.

106 Sharpe, "Losing ground."
} 
of the newly emerged and highly fragile Black middle class. Yet, in 1983, as the venture-capitalbacked microelectronics and biotechnology revolutions unfolded, the publication of "A Nation at Risk: The Imperative of Educational Reform," served as a forceful public recognition of the need for the United States to have an ample STEM-educated labor force that would include not only white males but also women, Blacks, and Hispanics. Released by President Reagan's Department of Education, "A Nation at Risk" raised the alarm concerning the need to make massive educational investments in the future U.S. labor force if the United States hoped to stay competitive in the global information economy. ${ }^{107}$

The Report cited a litany of deficiencies of the U.S. educational system, "amply documented in testimony received by the Commission," for producing a labor force relevant to the new "information age." 108 To wit (quoting from the report):

- International comparisons of student achievement, completed a decade ago, reveal that on 19 academic tests American students were never first or second and, in comparison with other industrialized nations, were last seven times.

- Some 23 million American adults are functionally illiterate by the simplest tests of everyday reading, writing, and comprehension.

- About 13 percent of all 17-year-olds in the United States can be considered functionally illiterate. Functional illiteracy among minority youth may run as high as 40 percent. Average achievement of high school students on most standardized tests is now lower than 26 years ago when Sputnik was launched.

- Over half the population of gifted students do not match their tested ability with comparable achievement in school.

- The College Board's Scholastic Aptitude Tests (SAT) demonstrate a virtually unbroken decline from 1963 to 1980. Average verbal scores fell over 50 points and average mathematics scores dropped nearly 40 points.

- College Board achievement tests also reveal consistent declines in recent years in such subjects as physics and English.

- Both the number and proportion of students demonstrating superior achievement on the SATs (i.e., those with scores of 650 or higher) have also dramatically declined.

- Many 17-year-olds do not possess the "higher order" intellectual skills we should expect of them. Nearly 40 percent cannot draw inferences from written material; only one-fifth can write a persuasive essay; and only one-third can solve a mathematics problem requiring several steps.

- There was a steady decline in science achievement scores of U.S. 17-year-olds as measured by national assessments of science in 1969, 1973, and 1977.

- Between 1975 and 1980, remedial mathematics courses in public 4-year colleges increased by 72 percent and now constitute one-quarter of all mathematics courses taught in those institutions.

- Average tested achievement of students graduating from college is also lower.

107 U.S. Department of Education, “A Nation at Risk: The Imperative of Educational Reform," A Report to the Nation and the Secretary of Education, United States Department of Education by The National Commission on Excellence in Education, April 1983, at https://www.edreform.com/wp-content/uploads/2013/02/A_Nation_At Risk_1983.pdf.

108 Ibid., p. 11. 
- Business and military leaders complain that they are required to spend millions of dollars on costly remedial education and training programs in such basic skills as reading, writing, spelling, and computation. The Department of the Navy, for example, reported to the Commission that one-quarter of its recent recruits cannot read at the ninth grade level, the minimum needed simply to understand written safety instructions. Without remedial work they cannot even begin, much less complete, the sophisticated training essential in much of the modern military.

The Report went on to warn that "these deficiencies come at a time when the demand for highly skilled workers in new fields is accelerating rapidly." 109

- Computers and computer-controlled equipment are penetrating every aspect of our lives - homes, factories, and offices.

- One estimate indicates that by the turn of the century millions of jobs will involve laser technology and robotics.

- Technology is radically transforming a host of other occupations. They include health care, medical science, energy production, food processing, construction, and the building, repair, and maintenance of sophisticated scientific, educational, military, and industrial equipment.

"The risk," the Report warned, "is not only that the Japanese make automobiles more efficiently than Americans and have government subsidies for development and export. It is not just that the South Koreans recently built the world's most efficient steel mill, or that American machine tools, once the pride of the world, are being displaced by German products."

It is also that these developments signify a redistribution of trained capability throughout the globe. Knowledge, learning, information, and skilled intelligence are the new raw materials of international commerce and are today spreading throughout the world as vigorously as miracle drugs, synthetic fertilizers, and blue jeans did earlier. If only to keep and improve on the slim competitive edge we still retain in world markets, we must dedicate ourselves to the reform of our educational system for the benefit of all—old and young alike, affluent and poor, majority and minority. Learning is the indispensable investment required for success in the "information age" we are entering.

The Report went on to spell out the social consequences of inaction in a fundamental upgrading of the educational system for all.

Our concern, however, goes well beyond matters such as industry and commerce. It also includes the intellectual, moral, and spiritual strengths of our people which knit together the very fabric of our society. The people of the United States need to know that individuals in our society who do not possess the levels of skill, literacy, and training essential to this new era will be effectively disenfranchised, not simply from the material rewards that accompany competent performance, but also from the chance to participate fully in our national life. A high level of shared education is essential to a free,

${ }^{109}$ Ibid., p. 12. 
democratic society and to the fostering of a common culture, especially in a country that prides itself on pluralism and individual freedom.

In the 1980s and 1990s, however, the agenda for educational reform was not enacted. Instead, children in downwardly mobile blue-collar households continued to receive inferior K-12 education in the nation's public schools. Tuitions and fees at public as well as private highereducation institutions skyrocketed, while even government-backed student loans to pay for higher education bore high interest rates, forcing students lacking family resources to take on onerous, and often unsustainable, debt to obtain a higher degree, or forego higher education altogether.

Meanwhile, as "A Nation at Risk" recognized, the demand for STEM labor by U.S. business enterprises and government agencies accelerated, along with, as the Report put it, "a redistribution of trained capability throughout the globe." And it was because U.S. employers were able in the decades that followed to gain ready access to the trained STEM capability from around the world - and in particular from Asian nations such as Taiwan, South Korea, India, and China - that the United States as a nation no longer seemed to be "at risk." With access to an enormous and expansive supply of highly qualified STEM labor, either by importing it from Asian nations that invested in a college-educated labor force or offshoring research and production activities to Asia, the "nation at risk" need for U.S. educational reform to stay competitive in global markets apparently disappeared. ${ }^{110}$

In short, instead of investing in upgrading the productive capabilities of Blacks and Hispanics as blue-collar middle-class jobs were disappearing through rationalization, U.S. business corporations and government agencies accessed ample supplies of the college-educated labor that the digital revolution required, both through migration of that labor from education-rich Asian nations to the United States and by offshoring employment requiring well-educated labor to Asia.

Table V.27 (above) shows the proportions of the total U.S. population made up of people of Asian ancestry, whether born in the United States or abroad, recorded in each decennial census from 1860 to 2020 . For the first 90 years, through the 1940s, Asians were largely excluded from the United States, never exceeding 0.21 percent of the total population. That began to change in the 1950s, 1960s, and 1970s, as Asians who were, in general, well-educated were admitted into the United States, with the proportion of Asians in the U.S. population more than doubling between 1970 and 1980, when it reached 1.55 percent. During these decades, there was widespread discussion about a "brain drain" that was depriving Asian economies of some of their brightest young people to the benefit of the United States. ${ }^{11}$ The growing importance of Asians in the U.S. population has continued over the past half century, with increases of 1.23 percent in the $1980 \mathrm{~s}, 1.45$ percent in the $1990 \mathrm{~s}, 1.38$ percent in the $2000 \mathrm{~s}$, and 1.63 percent in the $2010 \mathrm{~s}$.

Back in the decades spanning the U.S. Civil War, China had been a critical source of cheap, unskilled labor, as workers moved East so that the United States as a nation could move West. After 238,000 Chinese had immigrated to the United States in the 1850s through the 1870s,

110 Lazonick, Sustainable Prosperity, ch.5; William Lazonick, "The New Economy Business Model and the Crisis of U.S. Capitalism," Capitalism and Society, 4, 2, 2009: Article 4.

111 Lazonick, Sustainable Prosperity, ch. 5. 
primarily to work in gold mines and railroad construction, in 1882 Congress enacted the Chinese Exclusion Act. It would not be repealed until 1943. The Emergency Quota Act of 1921, the Immigration Act of 1924, and the Immigration and Naturalization Act of 1952 all placed national quotas on admissible immigrants based on the representations of the nation of origin in the U.S. population at prior census dates, with the 1952 quotas being based on the 1920 census.

As shown in Table V.28, in 1950 the largest group of Asian Americans was the Japanese, whose numbers tripled over the next decade, mainly because the 1952 Act permitted immigration of family members of U.S. citizens outside the quotas. ${ }^{112}$ Chinese were the next largest group. Japanese and Chinese admitted into the United States entered relatively well educated, and, according to Charles Hirschman and Morrison Wong, "the selective character of the immigrant stream strengthened the Asian-American community in a way that probably led to higher educational expectations for their children." 113

Table V.28: Ancestry of Asian Americans by nations of origin, 1950-2010

\begin{tabular}{|c|c|c|c|c|c|c|c|}
\hline Ancestry & 1950 & 1960 & 1970 & 1980 & 1990 & 2000 & 2010 \\
\hline TOTAL ASIAN & 321,033 & 877,934 & $1,438,542$ & $3,258,585$ & $6,908,638$ & $11,898,856$ & $17,320,856$ \\
\hline Chinese & 117,629 & 237,292 & 435,062 & 806,040 & $1,645,472$ & $2,720,437$ & $3,779,732$ \\
\hline Filipino & 61,636 & 176,310 & 343,060 & 774,652 & $1,406,770$ & $2,364,815$ & $3,416,840$ \\
\hline Indian & & & & 361,531 & 815,447 & $1,899,599$ & $3,183,063$ \\
\hline Vietnamese & & & & 261,729 & 614,547 & $1,233,736$ & $1,737,433$ \\
\hline Korean & & & & 354,593 & 798,849 & $1,228,427$ & $1,706,822$ \\
\hline Japanese & 141,768 & 464,332 & 591,290 & 700,040 & 847,562 & $1,148,932$ & $1,304,286$ \\
\hline Other Asian, not specified & & 0 & 69,130 & & 302,209 & 376,723 & 623,761 \\
\hline Pakistani & & & & & & 204,309 & 409,163 \\
\hline Cambodian & & & & & 147,411 & 206,052 & 276,667 \\
\hline Hmong & & & & & 90,082 & 186,310 & 260,073 \\
\hline Thai & & & & & 91,275 & 150,283 & 237,583 \\
\hline Laotian & & & & & 149,014 & 198,203 & 232,130 \\
\hline Taiwanese & & & & & & 130,391 & 215,441 \\
\hline Bangladeshi & & & & & & 57,412 & 147,300 \\
\hline Burmese & & & & & & 16,720 & 100,200 \\
\hline Indonesian & & & & & & 63,073 & 95,270 \\
\hline Nepalese & & & & & & 9,399 & 59,490 \\
\hline Sri Lankan & & & & & & 24,587 & 45,381 \\
\hline Malaysian & & & & & & 18,566 & 26,179 \\
\hline Bhutanese & & & & & & 212 & 19,439 \\
\hline Mongolian & & & & & & 5,868 & 18,344 \\
\hline Chinese and Taiwanese & & & & & & 14,404 & 14,941 \\
\hline Okinawan & & & & & & 10,599 & 11,326 \\
\hline Singaporean & & & & & & 2,394 & 5,347 \\
\hline Maldivian & & & & & & 51 & 127 \\
\hline Iwo Jiman & & & & & & 78 & 12 \\
\hline
\end{tabular}

Sources: U.S. Department of Commerce, U.S. Census Bureau, "Asian and Pacific Islander, for the United States, Regions, Divisions, and States, 1990," Appendix Table C-1, September 13, 2002; Gibson and Jung, "Historical Census Statistics on the ForeignBorn Population of the United States: 1850 to 2000"; Hoeffel, et al., "The Asian Population: 2010."

The Immigration and Nationality Act of 1965 ended the system of quotas based on national origins, opening the door to major increases in Asian immigration. Emphasizing family reunification and introducing specific employment-based preferences-that is, preferential

112 Charles Hirschman and Morrison G. Wong, "The Extraordinary Educational Attainment of Asian Americans: A Search for Historical Evidence and Explanations," Social Forces, 65, 1, 1986: 1-27, cited at p. 6. See also Jennifer Lee and Min Zhou, The Asian American Achievement Paradox, Russell Sage Foundation, 2015. On the history of the closing and then reopening of Asian immigration to the United States, see Jia Lynn Yang, One Mighty and Irresistible Tide: The Epic Struggle Over American Immigration, 1924-1965, W.W. Norton, 2020.

113 Hirschman and Morrison, "Extraordinary Educational Attainment," p. 10. 
admission to those with skills deemed to be in short supply in the United States - the 1965 Act favored more highly educated immigrants, resulting in what Jennifer Lee and Min Zhou have called the "hyper-selectivity" of the immigrant population based on educational attainment. ${ }^{114}$ Table V.28 displays the enormous increases in the number of Asian Americans, from various nations, in the decades subsequent to the 1965 Act. Through Asian immigration, U.S. employers gained access to a highly educated labor force for the "information age," without upgrading the educational opportunities of African Americans and Hispanic Americans.

In their study of the educational attainment of Chinese Americans and Vietnamese Americans, based on the 2010 census, Lee and Zhou show that, while only four percent of the population 25 years of age and older in China had bachelor's degrees, 50 percent of foreign-born Chinese in the United States had bachelor's degrees. In comparison, that educational attainment was 28 percent for the general U.S. population, 31 percent for non-Hispanic whites, and 18 percent for nonHispanic Blacks. Of foreign-born Vietnamese in the United States, 23 percent had bachelor's degrees, which was lower than the attainment of the general U.S. population, but far higher than the five percent of the 25-years-plus population of Vietnam with bachelor's degrees. In sharp contrast, only five percent of foreign-born Mexicans in the United States had bachelor's degrees, while the population of Mexico had a far higher level of attainment at 17 percent. ${ }^{115}$

Overall, in 2010, 49.0 percent of Asian Americans 25 years and older had at least a bachelor's degree (see Table V.29). Although 16.3 percent of foreign-born Asian Americans had less than a high-school education in 2010 compared with 4.7 percent for native-born Asian Americans, both groups had almost the same proportions with at least a bachelor's degree: 49.4 percent for nativeborn and 48.9 percent for foreign-born. With median household income in the U.S. general population in 2010 at $\$ 49,800$, median household income for Asian Americans was \$66,000; whites, \$54,000; Hispanics, \$40,000; and Blacks, \$33,000. Median household income of \$65,200 for foreign-born Asian Americans was only \$2,200 less than for native-born Asian Americans. ${ }^{116}$

As shown in Table V.29, with a median household income of $\$ 88,000$ and 87 percent foreign born, Indians lifted the foreign-born median for Asian Americans as a whole. Referring to foreign-born Indians, the Pew Research Center 2013 report, "The Rise of the Asian Americans," states: "In an economy that increasingly relies on highly skilled workers, they are the besteducated, highest-income, fastest-growing race group in the country."117

These labor-force outcomes were the result of U.S. government visa policy that, taking advantage of extraordinary investments in education by a number of East Asian nations, increasingly focused on attracting this "human capital" to the United States. Table V.30 shows the extent to which various national groups of Asians, and in particular Chinese, Filipinos, Indians, Koreans, and Vietnamese, entered the United States as the digital revolution was unfolding in the 1980s. The hyper-selectivity of Asian immigrants became even more pronounced with the passage of the Immigration Act of 1990, which increased the number of employment-based preferences for permanent visas to 140,000 per year from 56,000 per year,

\footnotetext{
${ }^{114}$ Lee and Zhou, Asian American Achievement Paradox, ch. 2; see also Madeline Y. Hsu, The Good Immigrants: How the Yellow Peril Became the Model Minority, Princeton University Press, chs. 8-9.

${ }^{115}$ Lee and Zhou, Asian American Achievement Paradox, p. 31.

${ }^{116}$ Pew Research Center, "The Rise of Asian Americans," April 4, 2013, at http://www.pewsocialtrends.org/2012/06/19/the-riseof-asian-americans/, pp. 2 and 10.

117 Ibid., p. 2.
} 
while greatly expanding the use of non-immigrant $\mathrm{H}-1 \mathrm{~B}$ visas for the specific purpose of attracting a high-tech labor force. ${ }^{118}$ In addition non-immigrant L-1 visas enable highly educated foreigners to work in the United States for five to seven years for the companies for which they were already employed abroad.

Table V.29: Income, education, and nativity of Asian American groups, 2010

\begin{tabular}{|l|r|r|c|c|}
\hline & $\begin{array}{c}\text { Population } \\
\text { in 2010 }\end{array}$ & $\begin{array}{c}\text { Median } \\
\text { household } \\
\text { income, \$ }\end{array}$ & $\begin{array}{c}\text { College } \\
\text { degree or } \\
\text { higher, \% }\end{array}$ & $\begin{array}{c}\text { Foreign } \\
\text { born, \% }\end{array}$ \\
\hline U.S. population & $308,745,538$ & 49,800 & 28 & 16 \\
\hline U.S. Asians & $17,320,856$ & 66,000 & 49 & 74 \\
\hline U.S. Asian groups & \multicolumn{5}{|l|}{} \\
\hline Chinese & $3,779,732$ & 65,500 & 51 & 76 \\
\hline Filipino & $3,416,840$ & 75,000 & 47 & 69 \\
\hline Indian & $3,183,063$ & 88,000 & 70 & 87 \\
\hline Vietnamese & $1,737,433$ & 53,400 & 26 & 84 \\
\hline Korean & $1,706,822$ & 50,000 & 53 & 78 \\
\hline Japanese & $1,304,286$ & 65,300 & 46 & 32 \\
\hline
\end{tabular}

Source: See Table V.27 for population data. The other data from Pew Research Center, "The Rise of Asian Americans," p. 18.

Table V.30: Asian Americans, 1990, by nativity and year of entry

\begin{tabular}{|c|c|c|c|c|c|c|c|}
\hline \multicolumn{5}{|c|}{ Persons 16 years and over, 1990} & \multicolumn{2}{|c|}{ Year of entry } & \multirow[b]{2}{*}{$\begin{array}{c}\text { \% before } \\
1980\end{array}$} \\
\hline & Total & Native & \begin{tabular}{|c|}
$\%$ \\
native
\end{tabular} & $\begin{array}{c}\text { Foreign } \\
\text { Born }\end{array}$ & $\begin{array}{c}\text { Before } \\
1980\end{array}$ & $\begin{array}{c}1980 \text { to } \\
1990\end{array}$ & \\
\hline All Asians & $5,167,530$ & $1,119,450$ & 22 & $4,048,080$ & $1,868,712$ & $2,179,368$ & 46 \\
\hline Chinese & $1,309,042$ & 255,369 & 20 & $1,053,673$ & 484,506 & 569,167 & 46 \\
\hline Chinese, except Taiwanese & $1,253,150$ & 251,124 & 20 & $1,002,026$ & 463,856 & 538,170 & 46 \\
\hline Taiwanese & 55,892 & 4,245 & 8 & 51,647 & 20,650 & 30,997 & 40 \\
\hline Filipino & $1,078,817$ & 229,060 & 21 & 849,757 & 459,383 & 390,374 & 54 \\
\hline Japanese & 724,683 & 472,932 & 65 & 251,751 & 126,588 & 125,163 & 50 \\
\hline Korean & 579,867 & 53,504 & 9 & 526,363 & 246,081 & 280,282 & 47 \\
\hline Indian & 576,157 & 40,607 & 7 & 535,550 & 240,524 & 295,026 & 45 \\
\hline Vietnamese & 423,121 & 14,707 & 3 & 408,414 & 172,216 & 236,198 & 42 \\
\hline Cambodian & 85,500 & 1,447 & 2 & 84,053 & 12,741 & 71,312 & 15 \\
\hline Hmong & 40,649 & 874 & 2 & 39,775 & 12,159 & 27,616 & 31 \\
\hline Laotian & 87,683 & 1,412 & 2 & 86,271 & 20,680 & 65,591 & 24 \\
\hline Thai & 71,907 & 6,276 & 9 & 65,631 & 39,163 & 26,468 & 60 \\
\hline Pakistani & 58,151 & 2,263 & 4 & 55,888 & 20,134 & 35,754 & 36 \\
\hline Indonesian & 24,965 & 2,015 & 8 & 22,950 & 9,284 & 13,666 & 40 \\
\hline
\end{tabular}

Source: U.S. Department of Commerce, United States Census Bureau, "Asians and Pacific Islanders in the United States," 1990 Census of the Population, Table 3, at https://www.census.gov/prod/cen1990/cp3/cp-3-5.pdf.

During the 1980s, there was concern in government agencies (particularly the National Science Foundation), research universities, and high-tech industries about whether, without a greatly

118 Lazonick, Sustainable Prosperity, ch. 5. 
increased influx of STEM workers from abroad, the existing U.S. labor force would provide the quantity and quality of science and engineering professionals that the microelectronics revolution was demanding. ${ }^{119}$ Some states launched initiatives to increase the engineers graduating from their universities. For example, in the early 1980s, the Massachusetts High Technology Council coordinated the " 2 percent solution" among the region's leading technology companies, the state government, and the public universities. The companies agreed to donate two percent of their annual R\&D budgets to the state's public universities to expand their engineering offerings. ${ }^{120}$ These business contributions (in some cases equipment rather than cash) did not in and of themselves finance a substantial growth of engineering education, but they sent a strong, and effective, signal to the Massachusetts government of the need for increased public funding.

By the mid-1980s, however, many graduates of U.S. engineering colleges were doing MBAs to secure jobs as Wall Street "quants." 121 Meanwhile, increasing numbers of foreign students, and especially Asians, received student visas to enroll in U.S. science and engineering programs. Figure V.2 shows the rising numbers and proportions of temporary-mainly F-1 - visa holders among graduate students in science and engineering at U.S. universities from 1980 to 2016.

The proportions of foreign students varied with booms and busts in the economy, and from the late 1990s the proportion of graduate students in engineering with temporary visas was greater than 50 percent of the total number of engineering graduate students, rising to 65 percent in 2015 and 2016. Asians and particularly Chinese have been dominant among holders of F-1 visas (for all levels of education, not just graduate studies), as shown in Figure V.3, which charts F-1 visa holders by country of origin for the ten nations with the highest numbers of visas in 2019 .

Table V.31 shows the percentage of the F-1 visas held by students from the top ten nations. Restrictions on travel during the COVID-19 pandemic resulted in a dramatic decline in the total number of F-1 visas issued, from 364,204 in 2019 to 111,387 in 2020. Asians held more than 50 percent of all F-1 visas in every year from 1997 through 2018, but the distribution across nations changed. In 1997 Chinese possessed 4.5 percent of all F-1 visas and Indians 4.0 percent, while South Koreans received 13.6 percent and Japanese 13.2 percent. The visa shares of Chinese and Indians increased in the late 1990s and first half of the 2000s, with both nations surpassing the share of the Japanese in 2006, but South Koreans still leading with 15.6 percent. The total number of visas issued exploded, tripling between 2003 and 2015, with Chinese becoming ever more numerous, holding 42.6 percent of all visas in the peak year of 2015.

119 See Eric R. Weinstein, "How and Why Government, Universities, and Industry Create Domestic Shortages of Scientists and High-Tech Workers," Institute for New Economic Thinking Commentary, March 28, 2017 (originally published by the National Bureau of Economic Research in 1998), at https:/www.ineteconomics.org/perspectives/blog/how-why-governmentuniversities-industry-create-domestic-labor-shortages-of-scientists-high-tech-workers; William Lazonick, "How the U.S. New Economy Business Model Has Devalued Science and Engineering PhDs," Institute for New Economic Thinking Commentary, May 9, 2017, at https://www.ineteconomics.org/perspectives/blog/marketization-and-financialization.

120 Elizabeth M. Fowler, "Financing engineers' education," New York Times, February 3, 1982; Elizabeth M. Fowler, "Focus on factory engineers," New York Times, June 29, 1983; Michael H. Best, The New Competitive Advantage: The Renewal of American Industry, Oxford University Press, 2001, p. 156.

121 Elizabeth M. Fowler, "Engineers and quest for M.B.A.," New York Times, January 9, 1985; Ben Zimmer, "Quants," New York Times Magazine, May 13, 2010, at https://www.nytimes.com/2010/05/16/magazine/16FOB-OnLanguage-t.html; Michelle Celarier, "How a misfit group of computer geeks and English majors transformed Wall Street," New York, January 18, 2018, at http://nymag.com/intelligencer/2018/01/d-e-shaw-the-first-great-quant-hedge-fund.html. 
Figure V.2: Full-time science and engineering graduate students in U.S. universities, 1980-2016, by type of visa

250,000



Source: National Science Foundation, National Center for Science and Engineering Statistics, "Survey of Graduate Students and Post-Doctorates in Science and Engineering, Fall 2016," at https://ncsesdata.nsf.gov/gradpostdoc/2016/.

Figure V.3: F-1 (student) visa holders, 1997-2019, for the ten countries with the highest number of nationals with F-1 visas in 2019

300,000

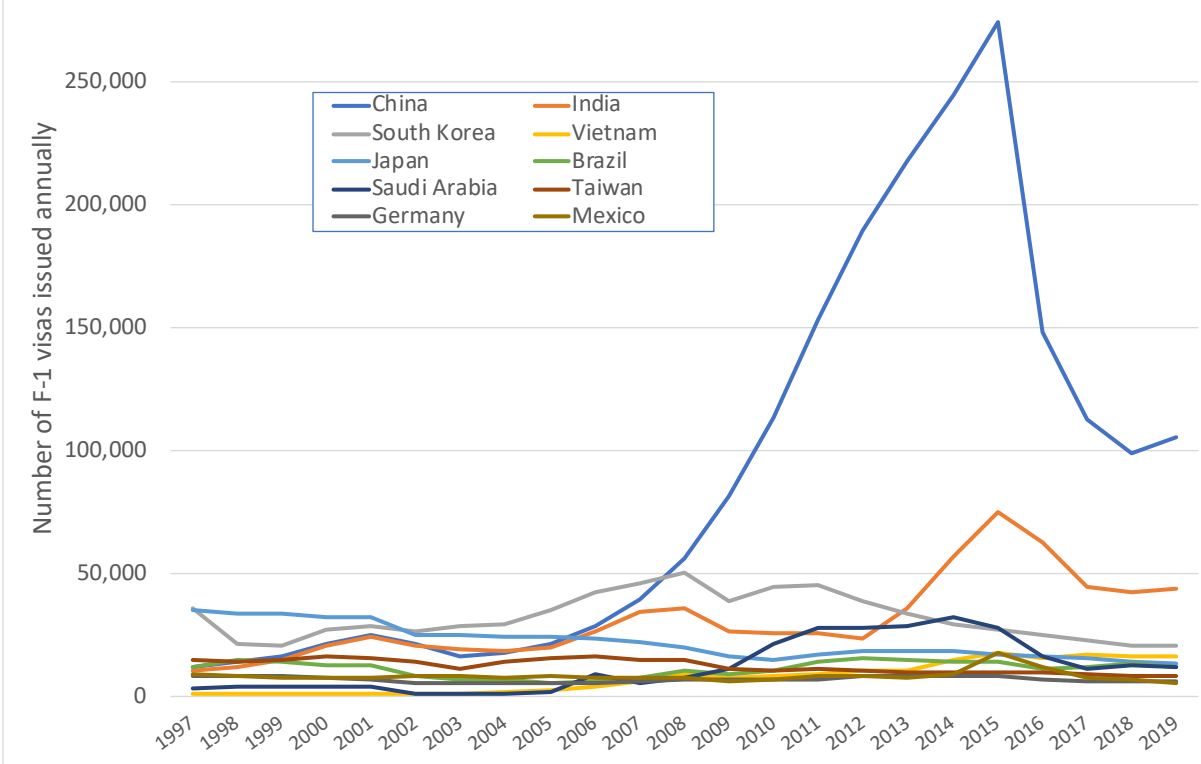

Source: U.S. Department of State, Nonimmigrant Visa Statistics, "FY1997-2020 NIV Detail Table (Excel spreadsheet)," at https://travel.state.gov/content/travel/en/legal/visa-law0/visastatistics/nonimmigrant-visa-statistics.html. 
Table V.31: F-1 visa holders, 1997-2019, by percentage shares of all F-1 visas issued by the ten countries with the highest number of nationals with F-1 visas in 2019

\begin{tabular}{|l|l|r|r|r|r|r|r|r|r|r|r|r|}
\hline & $\begin{array}{c}\text { Total F-1 } \\
\text { Visas }\end{array}$ & \multicolumn{1}{c|}{ Asia } & China & \multicolumn{1}{|c|}{ India } & $\begin{array}{c}\text { South } \\
\text { Korea }\end{array}$ & Vietnam & Japan & Brazil & $\begin{array}{c}\text { Saudi } \\
\text { Arabia }\end{array}$ & Taiwan & Germany & Mexico \\
\hline $\mathbf{1 9 9 7}$ & $\mathbf{2 6 6 , 4 8 3}$ & $\mathbf{5 5 . 8}$ & 4.5 & 4.0 & 13.6 & 0.4 & 13.2 & 4.6 & 1.3 & 5.6 & 3.1 & 3.5 \\
\hline $\mathbf{1 9 9 8}$ & $\mathbf{2 5 1 , 5 6 5}$ & $\mathbf{5 0 . 8}$ & 5.5 & 4.8 & 8.5 & 0.5 & 13.5 & 5.9 & 1.5 & 5.5 & 3.3 & 3.4 \\
\hline $\mathbf{1 9 9 9}$ & $\mathbf{2 6 2 , 5 4 2}$ & $\mathbf{5 1 . 7}$ & 6.2 & 5.8 & 8.0 & 0.3 & 12.9 & 5.3 & 1.5 & 5.6 & 3.1 & 2.9 \\
\hline $\mathbf{2 0 0 0}$ & $\mathbf{2 8 4 , 0 5 3}$ & $\mathbf{5 5 . 0}$ & 7.6 & 7.2 & 9.7 & 0.3 & 11.5 & 4.4 & 1.4 & 5.7 & 2.6 & 2.8 \\
\hline $\mathbf{2 0 0 1}$ & $\mathbf{2 9 3 , 3 5 7}$ & $\mathbf{5 6 . 0}$ & 8.6 & 8.2 & 9.9 & 0.4 & 11.0 & 4.3 & 1.5 & 5.4 & 2.3 & 2.7 \\
\hline $\mathbf{2 0 0 2}$ & $\mathbf{2 3 4 , 3 2 2}$ & $\mathbf{5 6 . 1}$ & 9.3 & 8.9 & 11.4 & 0.6 & 10.7 & 3.6 & 0.6 & 6.0 & 2.5 & 3.4 \\
\hline $\mathbf{2 0 0 3}$ & $\mathbf{2 1 5 , 6 9 5}$ & $\mathbf{5 6 . 9}$ & 7.5 & 8.9 & 13.3 & 0.6 & 11.5 & 3.3 & 0.5 & 5.3 & 2.5 & 4.0 \\
\hline $\mathbf{2 0 0 4}$ & $\mathbf{2 1 8 , 8 9 8}$ & $\mathbf{5 8 . 2}$ & 8.3 & 8.4 & 13.6 & 0.8 & 11.2 & 3.1 & 0.5 & 6.5 & 2.4 & 3.7 \\
\hline $\mathbf{2 0 0 5}$ & $\mathbf{2 3 7 , 8 9 0}$ & $\mathbf{6 0 . 3}$ & 9.1 & 8.5 & 14.8 & 1.0 & 10.3 & 2.5 & 0.9 & 6.5 & 2.3 & 3.4 \\
\hline $\mathbf{2 0 0 6}$ & $\mathbf{2 7 3 , 8 7 0}$ & $\mathbf{6 4 . 7}$ & 10.4 & 9.6 & 15.6 & 1.4 & 8.6 & 2.2 & 3.4 & 6.1 & 2.0 & 2.9 \\
\hline $\mathbf{2 0 0 7}$ & $\mathbf{2 9 8 , 3 9 3}$ & $\mathbf{6 5 . 4}$ & 13.2 & 11.6 & 15.4 & 2.1 & 7.3 & 2.5 & 1.9 & 5.0 & 2.0 & 2.6 \\
\hline $\mathbf{2 0 0 8}$ & $\mathbf{3 4 0 , 7 1 1}$ & $\mathbf{6 5 . 3}$ & 16.5 & 10.6 & 14.7 & 2.7 & 5.8 & 3.1 & 2.4 & 4.3 & 2.1 & 2.2 \\
\hline $\mathbf{2 0 0 9}$ & $\mathbf{3 3 1 , 2 0 8}$ & $\mathbf{6 6 . 6}$ & 24.7 & 8.1 & 11.8 & 2.3 & 5.0 & 2.8 & 3.4 & 3.3 & 2.2 & 1.9 \\
\hline $\mathbf{2 0 1 0}$ & $\mathbf{3 8 5 , 2 1 0}$ & $\mathbf{6 9 . 1}$ & 29.5 & 6.7 & 11.5 & 2.3 & 3.9 & 2.7 & 5.5 & 2.8 & 1.9 & 1.9 \\
\hline $\mathbf{2 0 1 1}$ & $\mathbf{4 4 7 , 4 1 0}$ & $\mathbf{7 1 . 2}$ & 34.2 & 5.7 & 10.2 & 2.1 & 3.8 & 3.2 & 6.2 & 2.5 & 1.6 & 1.9 \\
\hline $\mathbf{2 0 1 2}$ & $\mathbf{4 8 6 , 9 0 0}$ & $\mathbf{7 2 . 4}$ & 38.9 & 4.8 & 8.0 & 2.1 & 3.8 & 3.2 & 5.7 & 2.2 & 1.7 & 1.7 \\
\hline $\mathbf{2 0 1 3}$ & $\mathbf{5 3 4 , 3 2 0}$ & $\mathbf{7 3 . 8}$ & 40.7 & 6.8 & 6.3 & 2.0 & 3.5 & 2.8 & 5.4 & 1.9 & 1.6 & 1.5 \\
\hline $\mathbf{2 0 1 4}$ & $\mathbf{5 9 5 , 5 6 9}$ & $\mathbf{7 5 . 1}$ & 41.1 & 9.5 & 4.9 & 2.5 & 3.1 & 2.4 & 5.4 & 1.6 & 1.5 & 1.5 \\
\hline $\mathbf{2 0 1 5}$ & $\mathbf{6 4 4 , 2 3 3}$ & $\mathbf{7 6 . 5}$ & 42.6 & 11.6 & 4.2 & 2.7 & 2.7 & 2.2 & 4.4 & 1.5 & 1.3 & 2.7 \\
\hline $\mathbf{2 0 1 6}$ & $\mathbf{4 7 1 , 7 2 8}$ & $\mathbf{7 1 . 2}$ & 31.4 & 13.3 & 5.4 & 3.3 & 3.5 & 2.3 & 3.5 & 2.1 & 1.5 & 2.5 \\
\hline $\mathbf{2 0 1 7}$ & $\mathbf{3 9 3 , 5 7 3}$ & $\mathbf{6 8 . 2}$ & 28.7 & 11.4 & 5.8 & 4.3 & 4.1 & 3.1 & 2.9 & 2.3 & 1.7 & 1.9 \\
\hline $\mathbf{2 0 1 8}$ & $\mathbf{3 6 2 , 9 2 9}$ & $\mathbf{6 7 . 3}$ & 27.3 & 11.8 & 5.8 & 4.4 & 4.0 & 3.7 & 3.4 & 2.3 & 1.7 & 1.9 \\
\hline $\mathbf{2 0 1 9}$ & $\mathbf{3 6 4 , 2 0 4}$ & $\mathbf{6 8 . 8}$ & 29.0 & 12.0 & 5.8 & 4.6 & 3.8 & 3.4 & 3.2 & 2.3 & 1.7 & 1.6 \\
\hline
\end{tabular}

Note: Data are available for 2020, but because of the pandemic the total number of F-1 visas issued in 2020 declined significantly to 111,387 , with 14,436 to China, 15,323 to India, and 9,450 in South Korea.

Source: U.S. Department of State, Nonimmigrant Visa Statistics, "FY1997-2020 NIV Detail Table (Excel spreadsheet)."

After receiving higher education in the United States, many foreign nationals have wanted to extend their stays to gain job experience at U.S.-based business enterprises, government agencies, or civil-society organizations. Provisions of the Immigration Act of 1990 enable college-educated foreigners, especially those with computer-related skills, to work in the United States either as permanent residents, who can then become U.S. citizens after five years, or on temporary $\mathrm{H}-1 \mathrm{~B}$ and L-1 visas. U.S. high-tech employers lobbied for these changes in immigration law, and their interests prevailed. ${ }^{122}$

Indeed, with the rapid development of East Asia — dubbed "the East Asian miracle" by the World Bank in a 1993 publication ${ }^{123}$-U.S. employers found that the migration of educated and experienced labor could be a two-way street. With the demand for high-tech labor booming in the late 1980s, U.S. employers had to be concerned about the departure of experienced foreign nationals in the U.S. labor force, especially to South Korea and Taiwan, whose governments had instituted active policies to reverse the "brain drain" from their homelands to the United States that had been occurring since the late 1960s. ${ }^{124}$ In 1989 a Wall Street Journal article entitled "Costly Exports," had the subhead: "Reverse 'Brain Drain' Helps Asia but Robs U.S. of Scarce Talent-Korea in Particular Benefits as Scientists Return to Take Top Jobs." 125 At the time, there were an estimated 6,000 Korean nationals working as scientists or engineers in the United States.

122 Lazonick, Sustainable Prosperity, pp. 156-162.

123 The World Bank, The East Asian Miracle: Economic Growth and Public Policy, Oxford University Press, 1993.

124 Lazonick, Sustainable Prosperity, pp. 162-176.

125 Stephen Kreider Yoder, "Costly exports: Reverse 'brain drain' helps Asia but robs U.S. of scarce talent," Wall Street Journal, April 18, 1989. 
The Wall Street Journal story quoted Chin Hai Sool, director general of Korea's Ministry of Science and Technology, who said that Koreans in the United States "have become a precious resource for us."

In sharp contrast to the Korean perspective was the point of view of Americans concerned with the implications of the reverse brain drain for the supply of scientists and engineers in the United States. As Betty Vetter, executive director of the Commission on Professionals in Science and Technology, in Washington D.C., put it: "We've been counting on foreign graduates to stay here and fill our needs because we haven't been filling our own needs for a long time. There's nobody to replace these people." 126

By the early 1990s Korea had developed to a stage at which its economy could quickly tap this "precious resource": Korean nationals with advanced education and high-tech work experience in the United States. Of 13,878 foreign S\&E doctorate recipients with temporary visas from U.S. universities in 1990-91, 56 percent were from China $(2,779)$, Korea $(1,912)$, Taiwan $(1,824)$, or India $(1,235)$. In 199547 percent of the 1990-91 recipients were working in the United States, including 88 percent of the Chinese, 79 percent of the Indians, 42 percent of the Taiwanese, but only 11 percent of the Koreans - a proportion that was even lower than the 13 percent of the 227 Japanese doctoral recipients working in the United States. ${ }^{127}$

The prime purpose of the Immigration Act of 1990 was to bring Asians with STEM qualifications to the United States to join the U.S. labor force, either immediately or once they had finished their higher education in the United States. In addition to expansion of employmentbased preferences for permanent residents with their "green cards," H-1B and L-1 temporary immigration visas enabled foreigners with higher education to work in the United States for extended periods of time. These immigrant and non-immigrant visas resulted in a vast increase in STEM personnel available for employment in the United States, even as some experienced foreign-born members of the U.S. science and engineering labor force were migrating back to their places of birth because of new employment opportunities opening up there. ${ }^{128}$ As a result of this continued inflow of STEM personnel into the United States, the nation was, apparently no longer at risk, and U.S. business executives and government legislators abandoned any serious attempt to upgrade the educations of the now downwardly-mobile American working class —of whatever race or ethnicity.

On average, 14 percent of all immigrants annually have gained permanent residency by virtue of employment-based preference (EBP) visas. The beneficiaries are people whose existing education and skills, or in a small number of cases money, will, according to the assessment of the immigration authorities, add significant value to the U.S. economy. Table V.32, with data on the types of EBP immigrants admitted to the United States in 1995, 1996, and 1997, shows the importance of professionals within the EBP category.

126 Quoted in ibid.

127 Jean M. Johnson and Mark C. Regets, "International Mobility of Scientists and Engineers to the United States-Brain Drain or Brain Circulation?" National Science Foundation, Division of Science Resources Studies Issue Brief, NSF 98-316, 1998, at https://www.nsf.gov/statistics/issuebrf/sib98316.htm.

128 See AnnaLee Saxenian, The New Argonauts: Regional Advantage in a Global Economy, Harvard University Press, 2007; Ron Hira, "Bridge to Immigration or Cheap Temporary Labor? The H-1B and L-1 Visa Programs Are a Source of Both," EPI Briefing Paper \#257, Economic Policy Institute, February 17, 2010, at https://www.epi.org/publication/bp257/. 
Table V.32: Employment-based preferences (EBP) for admission of permanent residents to the United States, by category of admission, number of EBP visas, and percent of all permanent resident visas, 1995, 1996, and 1997

\begin{tabular}{|l|r|r|r|r|c|c|}
\hline \multirow{2}{*}{ Category of admission } & \multicolumn{2}{c|}{1995} & \multicolumn{2}{c|}{1996} & \multicolumn{2}{c|}{1997} \\
\cline { 2 - 7 } & Number & Percent & Number & Percent & Number & Percent \\
\hline Employment-based preferences & $\mathbf{8 5 , 3 3 6}$ & $\mathbf{1 1 . 8}$ & $\mathbf{1 1 7 , 4 9 9}$ & $\mathbf{1 2 . 8}$ & $\mathbf{9 0 , 6 0 7}$ & $\mathbf{1 1 . 3}$ \\
\hline Priority workers & 17,339 & 2.4 & $\mathbf{2 7 , 5 0 1}$ & 3.0 & 21,810 & 2.7 \\
\hline Professionals, advanced degree or exceptional ability & 10,475 & 1.5 & 18,462 & 2.0 & 17,059 & 2.1 \\
\hline Skilled, professionals, and unskilled & 50,245 & 7.0 & 62,756 & 6.9 & 42,596 & 5.3 \\
\hline Chinese Student Protection Act & 4,213 & 0.6 & 401 & 0.0 & 142 & 0.0 \\
\hline Needed unskilled workers & 7,884 & 1.1 & 11,849 & 1.3 & 8,702 & 1.1 \\
\hline Other skilled workers and professionals & 38,148 & 5.3 & 50,506 & 5.5 & 33,752 & 4.2 \\
\hline Special immigrants & 6,737 & 0.9 & 7,844 & 0.9 & 7,781 & 1.0 \\
\hline Investors & 540 & 0.1 & 936 & 0.1 & 1,361 & 0.2 \\
\hline
\end{tabular}

Source: U.S. Department of Justice, 1997 Statistical Yearbook of the Immigration and Naturalization Service, U.S. Government Printing Office, 1999, Table A, p. 19.

Figure V.4 charts the importance of Indian and Chinese nationals in receiving EBP permanentresident visas, while Table V.33 translates these numbers into proportions of EBP visas that, from 1996 through 2019, went to Asians and to the top ten nations in terms of total number of EBP visas over the entire 24 years.

Figure V.4: Employment-based preference (EBP) immigration visas, 1996-2019, by the ten nations with the most EBP visa holders over the 24-year period



Source: U.S. Department of Homeland Security, "Persons Obtaining Lawful Permanent Resident Status by Broad Class of Admission and Region and Country of Birth," Yearbook of Immigration Statistics, editions 1996 to 2019, at https://www.dhs.gov/immigration-statistics/yearbook. 
Table V.33: EBP visas, 1996-2019, and percent shares of these visas by the ten nations with the most EBP visa holders over the 24-year period

\begin{tabular}{|c|c|c|c|c|c|c|c|c|c|c|c|c|}
\hline & \multirow{2}{*}{\begin{tabular}{|c|}
$\begin{array}{c}\text { No. of EBP } \\
\text { visas }\end{array}$ \\
World \\
\end{tabular}} & \multicolumn{11}{|c|}{$\%$ of total employment-based preference immigration visas } \\
\hline & & Asia & India & China & Philippines & South Korea & Mexico & Canada & UK & Brazil & Pakistan & Taiwan \\
\hline 1996 & 117,499 & 50.5 & 8.4 & 13.8 & 7.6 & 5.2 & 3.0 & 7.4 & 4.8 & 1.7 & 1.4 & 3.2 \\
\hline 1997 & 90,607 & 50.7 & 9.7 & 14.9 & 7.6 & 5.1 & 3.4 & 5.8 & 4.4 & 1.3 & 1.7 & 3.0 \\
\hline 1998 & 77,517 & 44.9 & 11.2 & 9.8 & 4.4 & 5.2 & 3.8 & 6.0 & 4.6 & 1.7 & 1.7 & 3.1 \\
\hline 1999 & 56,817 & 45.0 & 8.8 & 8.9 & 6.7 & 6.2 & 4.3 & 6.7 & 4.9 & 2.1 & 2.2 & 2.5 \\
\hline 2000 & 107,024 & 54.4 & 14.4 & 12.7 & 9.3 & 5.0 & 3.5 & 6.7 & 4.9 & 2.0 & 1.8 & 2.5 \\
\hline 2001 & 179,195 & 59.3 & 21.8 & 12.5 & 6.7 & 4.7 & 4.1 & 5.9 & 4.7 & 1.9 & 1.8 & 2.6 \\
\hline 2002 & 174,968 & 61.2 & 24.5 & 11.8 & 7.2 & 5.3 & 4.3 & 5.4 & 4.3 & 2.0 & 1.9 & 1.8 \\
\hline 2003 & 82,137 & 63.0 & 25.0 & 9.1 & 11.9 & 5.2 & 4.0 & 5.3 & 3.7 & 1.8 & 1.7 & 1.4 \\
\hline 2004 & 155,330 & 61.8 & 24.7 & 10.0 & 10.0 & 5.6 & 4.7 & 4.3 & 4.1 & 2.3 & 1.7 & 1.5 \\
\hline 2005 & 246,877 & 53.2 & 19.3 & 8.4 & 7.4 & 6.5 & 6.6 & 5.0 & 4.4 & 3.6 & 1.9 & 1.2 \\
\hline 2006 & 159,081 & 50.7 & 10.8 & 6.0 & 14.9 & 6.8 & 5.6 & 4.0 & 4.0 & 3.5 & 2.0 & 1.1 \\
\hline 2007 & 162,176 & 56.8 & 17.7 & 8.6 & 10.6 & 7.0 & 7.3 & 4.1 & 3.6 & 2.6 & 2.0 & 1.6 \\
\hline 2008 & 166511 & 56.4 & 15.4 & 9.2 & 5.5 & 9.7 & 5.3 & 4.2 & 4.0 & 2.1 & 2.5 & 2.0 \\
\hline 2009 & 144,034 & 54.8 & 14.1 & 7.8 & 5.9 & 9.8 & 6.0 & 4.8 & 4.9 & 2.3 & 2.2 & 1.7 \\
\hline 2010 & 148,343 & 57.6 & 21.0 & 12.1 & 4.3 & 7.8 & 7.8 & 3.9 & 3.8 & 2.2 & 2.0 & 1.4 \\
\hline 2011 & 139,339 & 63.8 & 24.1 & 12.6 & 5.3 & 9.0 & 6.6 & 3.7 & 3.3 & 1.7 & 1.8 & 1.6 \\
\hline 2012 & 143,998 & 63.6 & 23.2 & 13.8 & 6.4 & 8.3 & 5.5 & 3.8 & 3.6 & 1.8 & 1.5 & 1.3 \\
\hline 2013 & 161,110 & 63.2 & 22.2 & 12.6 & 6.5 & 8.9 & 5.0 & 3.8 & 3.7 & 1.7 & 1.6 & 1.5 \\
\hline 2014 & 151,596 & 66.7 & 27.0 & 15.0 & 5.5 & 7.8 & 4.8 & 3.4 & 3.2 & 1.6 & 1.5 & 1.1 \\
\hline 2015 & 144,047 & 62.2 & 19.1 & 15.6 & 7.3 & 6.7 & 4.5 & 3.9 & 3.8 & 1.9 & 1.6 & 1.5 \\
\hline 2016 & 137,893 & 59.0 & 15.0 & 14.5 & 5.6 & 9.8 & 4.4 & 3.8 & 3.7 & 2.5 & 1.4 & 1.3 \\
\hline 2017 & 77,517 & 44.9 & 11.2 & 9.8 & 4.4 & 5.2 & 3.8 & 6.0 & 4.6 & 1.5 & 2.9 & 3.1 \\
\hline 2018 & 138,171 & 60.7 & 16.4 & 13.6 & 6.3 & 7.7 & 4.1 & 3.3 & 3.1 & 3.2 & 1.6 & 1.8 \\
\hline 2019 & 139,458 & 55.7 & 13.3 & 12.3 & 5.4 & 7.5 & 4.8 & 3.6 & 3.3 & 4.2 & 1.6 & 1.8 \\
\hline $1996-2019$ & $3,301,245$ & 57.5 & 18.2 & 11.4 & 7.3 & 7.1 & 5.1 & 4.6 & 4.0 & 2.3 & 1.8 & 1.8 \\
\hline
\end{tabular}

Source: U.S. Department of Homeland Security, "Persons Obtaining Lawful Permanent Resident Status by Broad Class of Admission and Region and Country of Birth."

Over the period 1996-2019, 61.0 percent of the 3.3 million EBP visas issued went to people born in Asia, with Indians holding 18.2 percent, Chinese 11.4 percent, Filipinos 7.3 percent, and Koreans 7.1 percent. The Asian share was 50.3 percent in 1996 and reached a peak of 66.7 percent in 2014, dominated by the Indian share at 27.0 percent and the Chinese share of 15.0 percent.

Since the Immigration Act of 1990, non-immigrant visas that are employment related have expanded greatly under the H-1B and L-1 classifications. Under the 1990 Immigration Act, which amended earlier legislation, an H-1B visa is issued for an initial period of three years, with the possibility of reapplying for extension for another three years. $\mathrm{H}-1 \mathrm{~B}$ visa holders can apply for permanent resident (i.e., immigrant) status, and employers of H-1B visa holders often sponsor the nonimmigrant for permanent resident status. ${ }^{129}$ The American Competitiveness for the $21^{\text {st }}$ Century Act of 1998 enabled H-1B visa holders to obtain one-year extensions while waiting to become permanent residents. In 2001 more than 228,000 non-immigrant visa holders

129 Hira, "A Bridge to Immigration". For a taste of the vigorous debate over the use and abuse of H-1B visas, see The Editors, "Do we need foreign technology workers?" New York Times, April 8, 2009, at https://roomfordebate.blogs.nytimes.com/2009/04/08/do-we-need-foreign-technology-workers/. For a recent documentation of the abuses of the H-1B visa program, see Ron Hira, "Congressional Testimony: The Impact of High-Skilled Immigration on U.S. Workers,” Economic Policy Institute, March 1, 2016, at https://www.epi.org/publication/congressional-testimonythe-impact-of-high-skilled-immigration-on-u-s-workers-4/. 
became permanent residents. ${ }^{130}$ Alternatively, former H-1B visa holders who have been out of the United States for at least one year can take a job with a new H-1B visa, valid for three years, again with the possibility of a further three-year extension. ${ }^{131}$

Created in 1970, the L-1 visa category enables a multinational corporation, whether based in the United States or elsewhere, to bring foreign employees from abroad to work for the company or an affiliate in the United States. The sponsoring firm must have employed an "intracompany transferee" continuously for one year in the previous three years "in a managerial or executive position or in a position where she gained specialized knowledge." Executives and managers enter on an L-1A visa and can work in the United States for up to seven years, whereas employees with specialized knowledge enter on an L-1B visa and can work for up to five years. $^{132}$

There is no cap on the number of L-1 visas that can be issued. Such was also the case with H-1 visas prior to the Immigration Act of $1990 .{ }^{133}$ The number of $\mathrm{H}-1$ visas issued doubled from about 10,000 in 1969 to 20,000 in 1979 , and then climbed to almost 49,000 in $1989 .{ }^{134}$ Whether or not there was a high-tech "labor shortage" was a highly politicized issue. ${ }^{135}$ In the late 1980 s, a National Science Foundation prediction of an impending shortage of scientists and engineers bolstered high-tech industry's demand for more employment-based immigrant visas and H-1B and L-1 nonimmigrant visas. ${ }^{136}$ In the Congressional hearings that preceded the Immigration Act of 1990, labor economist Vernon Briggs advocated limits on the availability of high-tech visas: "I believe strongly that labor shortages are wonderful, and we should never do anything to eliminate that pressure, because it is forcing us to ask all the right questions about education and health, antidiscrimination policy, all the right policies are in place."137

Michael Teitelbaum, a demographer who was a program officer at the Sloan Foundation, argued against legislation that would succumb to declarations by business interests that they faced critical labor shortages, declaring that "what many employers and non-experts call 'labor shortages' are really mismatches between the skills needed and those being provided by U.S.

130 Jessica Vaughan, "Shortcuts to Immigration: The 'Temporary’ Visa Program is Broken,” Backgrounder. Washington, DC: Center for Immigration Studies, January 1, 2003, at https://cis.org/Report/Shortcuts-Immigration-Temporary-Visa-ProgramBroken.

131 Stephen Yale-Loehr, "Examining the Importance of the H-1B Visa to the American Economy," Testimony before the U.S. Senate Committee on the Judiciary, September 16, 2003, at https://www.judiciary.senate.gov/imo/media/doc/yaleloehr testimony $09 \quad 16 \quad$ 03.pdf.

132 Stephen Yale-Loehr, "The L-1 Visa and American Interests in the 21st Century Global Economy," Testimony before the U.S. Senate Committee on the Judiciary Subcommittee on Immigration and Border Security, July 29. 2003, at https://www.jackson-hertogs.com/testimony-by-stephen-yale-loehr-on-1-1-visas/

133 The H-1 visa for foreigners of "distinguished merit and ability" became known as the H-1B visas when a special category of H-1A visas was created for registered nurses under the Immigration Nursing Relief Act of 1989. See Stanley Mailman and Stephen Yale-Loehr, "Foreign nurses: Dealing with the shortage." New York Law Journal, December 22, 2003.

134 B. Lindsay Lowell, "H-1B Temporary Workers: Estimating the Population," Center for Comparative Immigration Studies Working Paper No. 12. University of California, San Diego, May 2000, p. 3, at https://escholarship.org/uc/item/4ms039dc.

135 See U.S. House of Representatives, "Joint Hearings before the Subcommittee of Immigration, Refugees, and International Law of the Committee of the Judiciary and the Immigration Task Force of the Committee on Education and Labor," 101st Congress, Second Session, on S. 358, H.R. 672, H.R. 2448, H.R. 2646, and H.R 4165, Immigration Act of 1989, February 21, March 1, 7, 13, and 14, 1990.

136 See Weinstein, "How and Why Government."

137 U.S. House of Representatives, "Joint Hearings before the Subcommittee of Immigration," p. 298; quoted in Weinstein, "How and Why Government." 
educational systems; hence the focus should be on educational and on-the-job training systems, to make them relate more effectively to labor demands, as do those in Germany and Japan."138

In the ultimate passage of the Immigration Act of 1990, however, high-tech business interests prevailed. The Bill that was enacted set the annual cap of initial H-1B visas at 65,000 , about 16,000 more than the number issued in 1989 , rather than the 25,000 cap that labor interests had been advocating. The change was influenced by lobbying efforts from the business community. ${ }^{139}$ Upon his election as president of the American Immigration Lawyers Association in 1988, H. Ronald Klesko declared: "This will be the year of business immigration. We will focus on creating a business immigration coalition composed of business leaders, chambers of commerce, human resource groups, corporate counsels, state development agency leaders and the immigration bar." "In November 1990, on the eve of the signing of the new Immigration Act by President George Bush, Harris N. Miller, coordinator of the Business Immigration Coalition, representing 250 companies and business associations formed to lobby for the new bill, told a New York Times reporter: "We're very concerned about shortages of skilled people, particularly in the sciences and engineering, computer science and mathematics."141 In 1991, with the Immigration Act in place, Miller remarked: "We were successful because we refashioned the debate from the jobs displacement issue, where we always lost, to the competitive issue." 142

Miller remained a key figure in the lobby for the free flow of the global ICT labor force into the United States. In 1995, he became president of the Information Technology Association of America (ITAA), a position he retained until 2006 when he quit to stage an unsuccessful campaign for the Democratic nomination in Virginia as candidate for the U.S. Senate. As a leading trade association for the ICT industries, ITAA was in the forefront of lobbying efforts that resulted in securing the American Competitiveness and Workforce Improvement Act of 1998. This legislation raised the annual H-1B cap to 115,000 initial visas in fiscal-years 1999 and 2000. ${ }^{143}$ The American Competitiveness for the $21^{\text {st }}$ Century Act of 2000 raised the annual cap to 195,000 initial visas in FY2001-2003. As of October 1, 2003, the annual cap of 65,000 was restored, but with an extra 20,000 visas available to foreign-born professionals who have an advanced degree from a U.S. institution of higher education. ${ }^{144}$

In 2007 and 2008, Congress debated an increase in the H-1B cap. Any such change, however, would now have to be enacted as part of Comprehensive Immigration Reform, legislation that includes a process for legalizing the status of illegal immigrants, almost all of whom are poorly educated and low paid. In effect, high-tech business interests found their efforts to have the H-1B cap raised stalled by the failure in Congress to reform of illegal immigration laws.

138 U.S. House of Representatives, "Joint Hearings before the Subcommittee of Immigration,” p. 572; see also Michael S. Teitelbaum, “Too Many Engineers, Too Few Jobs.” New York Times, March 19, 1996.

139 Joan C. Szabo, “Opening Doors for Immigrants,” Nation's Business, August 1, 1989.

140 “American Immigration Lawyers Association Elects New President," PR Newswire, July 19, 1988.

141 Anthony DePalma, "Graduate schools fill with foreigners," New York Times, November 29, 1990.

142 Susan Lee, "Train "em here: Foreign students crowd our schools for advanced scientific and engineering education," Forbes, 147, 11, 1991: 110-116.

143 The relevant fiscal year runs from October 1 to September 30.

144 Of the 65,000 visas that can be issued annually, 6,800 are set aside for Chile and Singapore under the terms of U.S. trade agreements with those countries. If any of these 6,800 visas are unused, they are added to the next year's visa cap. See AFLCIO, "Guest worker visas: The H-1B and the L-1," 2017 Fact Sheet, Department of Professional Employees, AFL-CIO, at https://dpeaflcio.org/programs-publications/issue-fact-sheets/guest-worker-visas-the-h-1b-and-1-1/. 
In Congressional hearings in 2007, Bill Gates of Microsoft argued:

Unfortunately, America's immigration policies are driving away the world's best and brightest precisely when we need them most. The terrible shortfall in our visa supply for the highly skilled stems not from security concerns, but from visa policies that have not been updated in over a decade and a half. We live in a different economy now. Simply put: It makes no sense to tell well-trained, highly skilled individuals - many of whom are educated at our top colleges and universities - that the United States does not welcome or value them. For too many foreign students and professionals, however, our immigration policies send precisely this message. ${ }^{145}$

Indian IT services companies such as TCS, Infosys, Wipro, Cognizant, and HCL Technologies have been among the biggest users of $\mathrm{H}-1 \mathrm{~B}$ visas, ${ }^{146}$ although these companies have complained that the U.S. government has disproportionately rejected their requests for visa extensions relative to U.S. corporations. ${ }^{147}$

Figure V.5 charts the number of H-1B visas issued from 1997 to 2019 for both first-stage and second-stage three-year periods by the countries of birth of people working in the United States on these visas, for the ten largest H-1B nations in 2019. The vast majority of H-1B visa holders have previous higher education related to ICT, and many of them also have acquired ICT skills through post-university employment in their home countries. The number of visas issued has varied with the changing legislative caps as well as with the economy's booms and busts (the bursting of the Internet bubble in early 2000s and the financial crisis of 2008-2009). In 2020, pandemic-related restrictions on cross-border movements of people resulted in a decline in $\mathrm{H}-1 \mathrm{~B}$ visas issued from 188,123 in 2019 to 124,983 in 2020.

Indians have dominated as beneficiaries of $\mathrm{H}-1 \mathrm{~B}$ visas, and since the mid-2000s Chinese have been a rising presence. Table V.34 shows the percentage shares of the top ten H-1B nations in 2019 for 1997 to 2019. In 199759.3 percent of H-1B visas went to Asians, and by 2018 this proportion had risen to 90.3 percent, with Indians' share increasing by over 30 percentage points over these 21 years. Indeed, even with Asians having a three-fifth share of H-1B visas in 1997, in 2020 Indians alone had 63 percent more H-1B visas than the total number issued to all foreign nationals in 1997. Meanwhile, the number of H-1B visas issued to Chinese increased by almost nine times from 1997 to 2019, with the Chinese share of annual visas increasing from 4.0 percent to 15.1 percent (see Table V.34).

Similarly, Figure V.6 and Table V.35 show the data for L-1 visas, in total and for the ten largest L-1 nations in 2019 for the 23 years from 1997 through 2019. As with H-1B visas, Indians are by

145 Peter Elstrom, "Gates to Senate: More visas,” Business Week, March 8, 2007.

146 Ron Hira, "Top ten users of H-1B guest worker program are all offshore outsourcing firms," Economic Policy Institute, February 14, 2013.

147 Ayan Pramanik and Priyanka Sangani, "H-1B extension rejections rob Indian IT firms of visa power," Economic Times, March 8, 2018, at https://economictimes.indiatimes.com/nri/visa-and-immigration/h-1b-extension-rejections-rob-indian-itfirms-of-visa-power/articleshow/68312136.cms. See also Louise Radnofsky, “Approval rate declined for H-1B visas,” Wall Street Journal, February 23, 2019, at https:/www.wsj.com/articles/approval-rate-declines-for-h-1b-visas-11550926800. 
far the largest beneficiaries of L-1 visas, but their dominance is much less marked. Chinese have been far less prominent as employees on L-1 visas than on H-1B visas. Travel restrictions in the pandemic resulted in a decline in L-1 visas issued from 76,988 in 2019 to 35,942, in 2020.

Figure V.5: H-1B visas, 1997-2019, the ten nations with the most H-1B visa holders in 2019

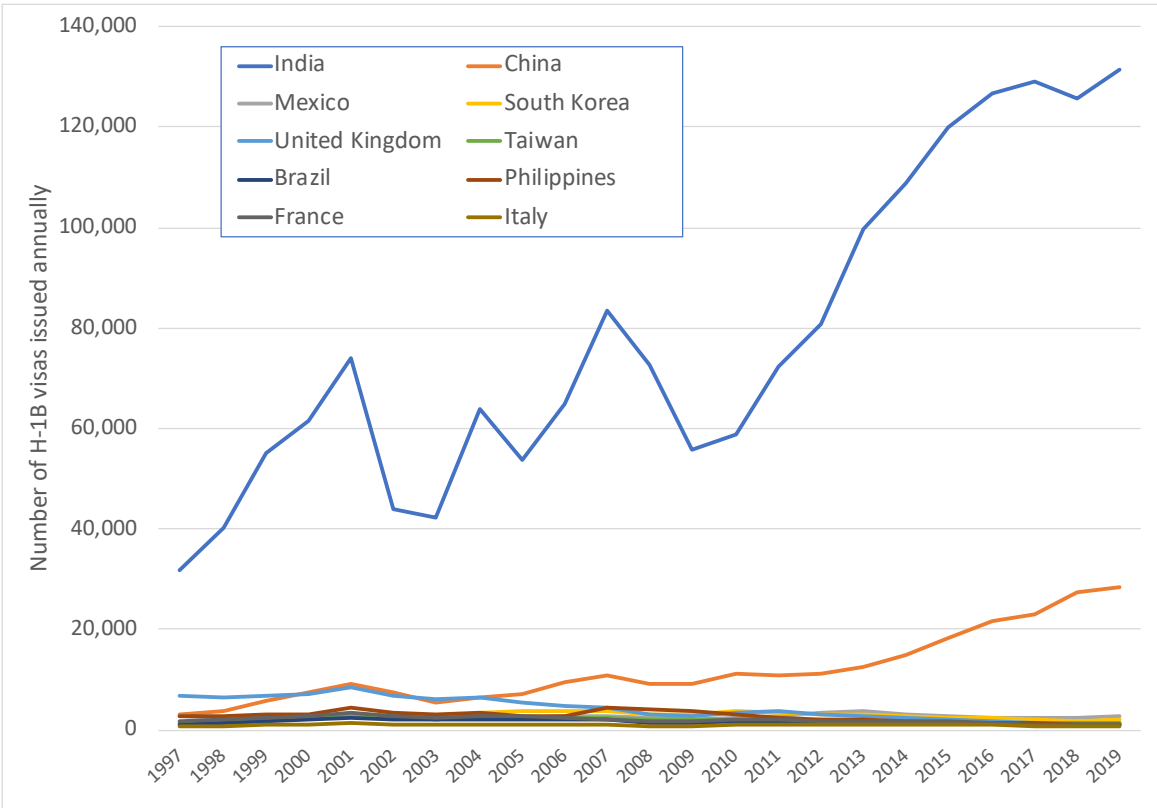

Source: U.S. Department of State, Nonimmigrant Visa statistics, “FY1997-2018 NIV Detail Table (Excel spreadsheet)."

Table V.34: Shares of H-1B visas, 1997-2019, Asia and the ten nations with the most H-1B visa holders in 2019

\begin{tabular}{|c|c|c|c|c|c|c|c|c|c|c|c|c|}
\hline & \multirow{2}{*}{\begin{tabular}{|c|}
$\begin{array}{c}\text { No. of } \mathrm{H}-1 \mathrm{~B} \\
\text { visas }\end{array}$ \\
World \\
\end{tabular}} & \multicolumn{11}{|c|}{$\%$ of total $\mathrm{H}-1 \mathrm{~B}$ visas } \\
\hline & & $\begin{array}{c}\text { Asia } \\
\text { (total) }\end{array}$ & India & China & Mexico & $\begin{array}{l}\text { South } \\
\text { Korea }\end{array}$ & $\begin{array}{c}\text { United } \\
\text { Kingdom }\end{array}$ & Taiwan & Brazil & Philippines & France & Italy \\
\hline 1997 & 80,547 & 59.3 & 39.3 & 4.0 & 3.5 & 1.1 & 8.6 & 1.8 & 1.3 & 3.3 & 2.4 & 1.0 \\
\hline 1998 & 91,360 & 63.8 & 44.1 & 4.2 & 2.5 & 1.0 & 6.9 & 1.9 & 1.4 & 3.0 & 2.3 & 0.9 \\
\hline 1999 & 116,513 & 68.4 & 47.3 & 5.0 & 2.1 & 1.6 & 5.7 & 1.9 & 1.4 & 2.6 & 2.1 & 0.8 \\
\hline 2000 & 133,290 & 68.7 & 46.2 & 5.6 & 1.8 & 1.7 & 5.5 & 2.0 & 1.4 & 2.3 & 2.1 & 0.8 \\
\hline 2001 & 161,643 & 68.3 & 45.8 & 5.6 & 1.8 & 1.8 & 5.2 & 1.8 & 1.5 & 2.8 & 2.1 & 0.8 \\
\hline 2002 & 118,352 & 61.5 & 37.2 & 6.4 & 2.5 & 2.5 & 5.8 & 2.2 & 1.8 & 2.9 & 2.5 & 0.9 \\
\hline 2003 & 107,196 & 61.6 & 39.4 & 5.2 & 2.5 & 2.7 & 5.7 & 1.9 & 1.9 & 2.8 & 2.4 & 0.9 \\
\hline 2004 & 138,965 & 66.6 & 45.9 & 4.7 & 2.2 & 2.5 & 4.7 & 1.9 & 1.6 & 2.5 & 2.0 & 0.9 \\
\hline 2005 & 124,099 & 66.0 & 43.2 & 5.7 & 2.0 & 3.1 & 4.5 & 2.0 & 1.6 & 2.3 & 2.1 & 0.9 \\
\hline 2006 & 135,421 & 70.7 & 47.9 & 7.0 & 2.0 & 2.9 & 3.5 & 1.9 & 1.5 & 2.1 & 1.8 & 0.8 \\
\hline 2007 & 154,053 & 75.6 & 54.2 & 7.0 & 1.9 & 2.5 & 2.9 & 1.6 & 1.3 & 2.8 & 1.4 & 0.6 \\
\hline 2008 & 129,464 & 77.3 & 56.0 & 7.1 & 1.9 & 2.5 & 2.4 & 1.5 & 1.1 & 3.1 & 1.4 & 0.7 \\
\hline 2009 & 110,367 & 74.9 & 50.6 & 8.4 & 2.0 & 2.9 & 2.6 & 1.9 & 1.3 & 3.3 & 1.5 & 0.8 \\
\hline 2010 & 117,409 & 74.5 & 50.0 & 9.6 & 2.1 & 3.1 & 3.0 & 1.8 & 1.4 & 2.7 & 1.7 & 0.9 \\
\hline 2011 & 129,134 & 76.4 & 56.1 & 8.4 & 2.0 & 2.7 & 2.8 & 1.3 & 1.2 & 1.8 & 1.6 & 0.8 \\
\hline 2012 & 135,530 & 78.3 & 59.5 & 8.2 & 2.6 & 2.3 & 2.2 & 1.2 & 1.2 & 1.5 & 1.4 & 0.9 \\
\hline 2013 & 153,223 & 82.3 & 65.1 & 8.2 & 2.4 & 2.0 & 1.8 & 1.0 & 0.9 & 1.4 & 1.2 & 0.7 \\
\hline 2014 & 161,369 & 84.5 & 67.4 & 9.2 & 2.0 & 1.7 & 1.6 & 0.9 & 0.8 & 1.1 & 1.1 & 0.6 \\
\hline 2015 & 172,748 & 86.7 & 69.4 & 10.6 & 1.7 & 1.5 & 1.2 & 0.8 & 0.7 & 0.8 & 0.9 & 0.6 \\
\hline 2016 & 180,057 & 88.5 & 70.4 & 12.0 & 1.4 & 1.3 & 1.0 & 0.8 & 0.7 & 0.8 & 0.8 & 0.5 \\
\hline 2017 & 179,049 & 90.2 & 72.1 & 12.8 & 1.3 & 1.1 & 0.8 & 0.7 & 0.6 & 0.7 & 0.7 & 0.4 \\
\hline 2018 & 179,660 & 90.3 & 69.9 & 15.3 & 1.4 & 1.0 & 0.8 & 0.7 & 0.6 & 0.7 & 0.6 & 0.5 \\
\hline 2019 & 188,123 & 90.2 & 69.9 & 15.1 & 1.5 & 1.1 & 0.7 & 0.7 & 0.6 & 0.6 & 0.6 & 0.5 \\
\hline
\end{tabular}

Note: Data are available for 2020, but because of the pandemic the total number of $\mathrm{H}-1 \mathrm{~B}$ visas issued in 2020 declined significantly to 124,983 , with 94,558 to India, 14,600 to China, and 1,552 to Mexico.

Source: U.S. Department of State, Nonimmigrant Visa statistics, "FY1997-2018 NIV Detail Table (Excel spreadsheet)." 
Figure V.6: L-1 visas, 1997-2019, the ten nations with the most L-1 visa holders in 2019

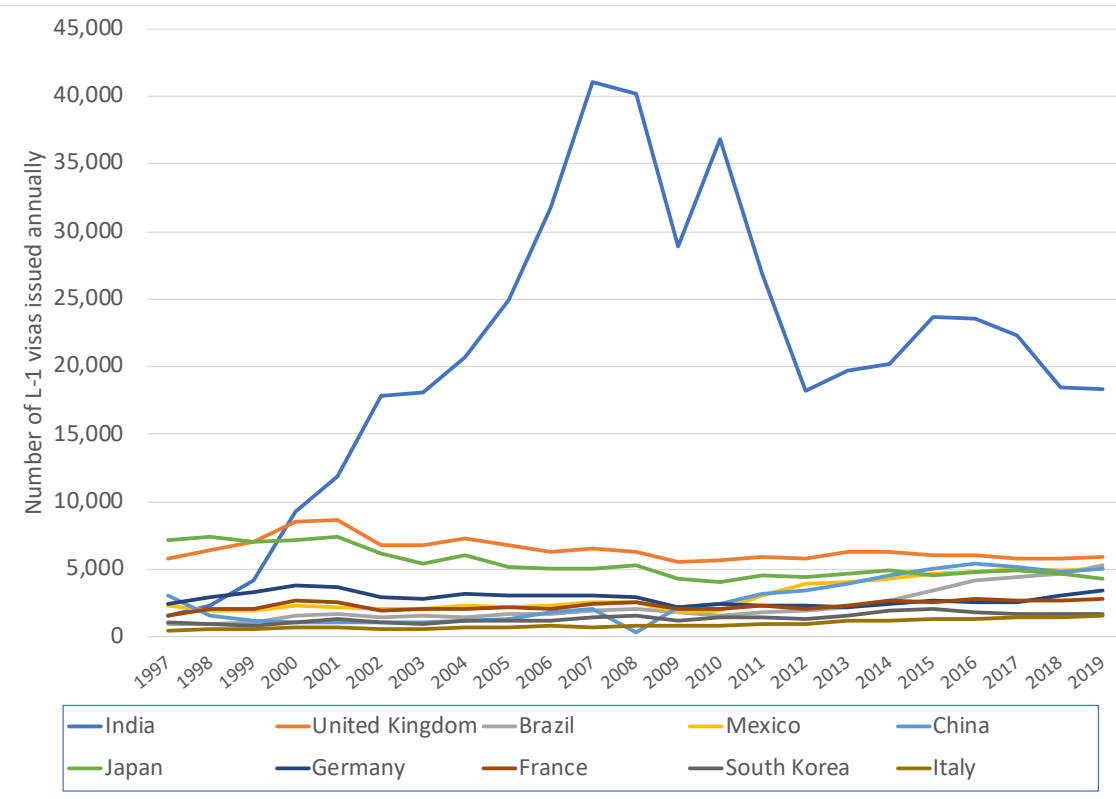

Source: U.S. Department of State, Nonimmigrant Visa statistics, "FY1997-2020 NIV Detail Table (Excel spreadsheet)."

Table V.35: Shares of L-1 visas, 1997-2019, Asia and the ten nations with the most L-1 visa holders in 2019

\begin{tabular}{|c|c|c|c|c|c|c|c|c|c|c|c|c|}
\hline & \multirow{2}{*}{\begin{tabular}{|c|}
$\begin{array}{c}\text { No. of } \mathrm{L}-1 \\
\text { visas }\end{array}$ \\
World \\
\end{tabular}} & \multicolumn{11}{|c|}{$\%$ of total L-1 visas } \\
\hline & & $\begin{array}{c}\text { Asia } \\
\text { (total) }\end{array}$ & India & \begin{tabular}{|c|} 
United \\
Kingdom
\end{tabular} & Brazil & Mexico & China & Japan & Germany & France & $\begin{array}{l}\text { South } \\
\text { Korea }\end{array}$ & Italy \\
\hline 1997 & 36,589 & 40.7 & 4.4 & 16.0 & 2.7 & 6.4 & 8.3 & 19.5 & 6.7 & 4.1 & 3.0 & 1.4 \\
\hline 1998 & 38,307 & 37.6 & 5.9 & 16.6 & 2.6 & 5.0 & 4.0 & 19.3 & 7.8 & 5.3 & 2.6 & 1.5 \\
\hline 1999 & 41,739 & 37.6 & 10.1 & 16.8 & 2.7 & 4.7 & 2.8 & 16.8 & 7.8 & 5.0 & 2.0 & 1.4 \\
\hline 2000 & 54,963 & 40.1 & 16.9 & 15.6 & 2.9 & 4.2 & 2.0 & 13.0 & 6.9 & 4.9 & 2.0 & 1.4 \\
\hline 2001 & 59,384 & 42.9 & 20.1 & 14.6 & 2.8 & 3.7 & 1.8 & 12.4 & 6.3 & 4.3 & 2.1 & 1.2 \\
\hline 2002 & 57,721 & 50.9 & 30.9 & 11.7 & 2.6 & 3.5 & 1.9 & 10.6 & 5.1 & 3.5 & 1.9 & 1.1 \\
\hline 2003 & 57,245 & 50.2 & 31.7 & 11.9 & 2.8 & 3.6 & 1.9 & 9.5 & 4.9 & 3.5 & 1.7 & 1.1 \\
\hline 2004 & 62,700 & 52.1 & 32.9 & 11.6 & 2.3 & 3.6 & 1.9 & 9.7 & 5.1 & 3.2 & 1.8 & 1.1 \\
\hline 2005 & 65,458 & 55.5 & 38.1 & 10.4 & 2.6 & 3.3 & 2.0 & 7.9 & 4.6 & 3.3 & 1.9 & 1.0 \\
\hline 2006 & 72,613 & 60.7 & 43.8 & 8.7 & 2.4 & 3.3 & 2.6 & 7.0 & 4.2 & 2.9 & 1.6 & 1.1 \\
\hline 2007 & 84,532 & 64.4 & 48.5 & 7.8 & 2.3 & 3.0 & 2.4 & 5.9 & 3.6 & 2.8 & 1.7 & 0.9 \\
\hline 2008 & 84,078 & 64.0 & 47.7 & 7.5 & 2.5 & 3.1 & 0.5 & 6.4 & 3.5 & 3.0 & 1.9 & 1.0 \\
\hline 2009 & 64,696 & 62.0 & 44.7 & 8.6 & 2.8 & 2.7 & 3.4 & 6.7 & 3.5 & 3.1 & 1.9 & 1.2 \\
\hline 2010 & 74,719 & 65.0 & 49.3 & 7.7 & 2.2 & 2.6 & 3.3 & 5.5 & 3.3 & 2.8 & 1.9 & 1.1 \\
\hline 2011 & 70,728 & 57.6 & 38.1 & 8.3 & 2.6 & 4.4 & 4.6 & 6.5 & 3.3 & 3.3 & 2.0 & 1.4 \\
\hline 2012 & 62,430 & 50.6 & 29.1 & 9.2 & 3.0 & 6.2 & 5.6 & 7.2 & 3.6 & 3.4 & 2.1 & 1.6 \\
\hline 2013 & 66,700 & 50.6 & 29.5 & 9.4 & 3.2 & 6.1 & 6.0 & 7.0 & 3.3 & 3.6 & 2.4 & 1.7 \\
\hline 2014 & 71,513 & 50.0 & 28.2 & 8.8 & 3.7 & 6.0 & 6.3 & 6.8 & 3.5 & 3.8 & 2.7 & 1.7 \\
\hline 2015 & 78,537 & 51.3 & 30.2 & 7.7 & 4.3 & 6.0 & 6.4 & 5.8 & 3.5 & 3.4 & 2.6 & 1.7 \\
\hline 2016 & 79,306 & 50.7 & 29.6 & 7.6 & 5.2 & 6.1 & 6.8 & 6.0 & 3.3 & 3.6 & 2.3 & 1.7 \\
\hline 2017 & 78,178 & 49.5 & 28.6 & 7.5 & 5.6 & 6.4 & 6.6 & 6.3 & 3.4 & 3.5 & 2.2 & 1.9 \\
\hline 2018 & 74,388 & 46.0 & 24.8 & 7.8 & 6.4 & 6.7 & 6.4 & 6.3 & 4.1 & 3.6 & 2.3 & 1.9 \\
\hline 2019 & 76,988 & 44.6 & 23.8 & 7.7 & 6.9 & 6.6 & 6.6 & 5.6 & 4.5 & 3.7 & 2.2 & 2.0 \\
\hline
\end{tabular}

Note: Data are available for 2020 , but because of the pandemic the total number of L-1 visas issued in 2020 declined significantly to 35,942, with 9,716 to India, 2,845 to United Kingdom, 2,207 to Brazil, and 2,417 to Mexico.

Source: U.S. Department of State, Nonimmigrant Visa statistics, "FY1997-2018 NIV Detail Table (Excel spreadsheet)." 


\section{d) Social networks and African American access to high-technology employment}

As is generally the case in all specialized endeavors that depend on organizational learning, access to relevant higher education and access to relevant employment experience are essential for building productive and remunerative careers in STEM occupations. In terms of access to higher education and work experience by minority groups in the U.S. labor force, people of Asian origin-including those born in the United States, naturalized citizens, permanent residents, non-immigrant student and work visa holders - have made remarkable progress in STEM occupations in general and as "professionals" at the leading tech companies that we have investigated. As a nation engaged in industrial innovation, the United States and the business enterprises that are foundational to the U.S. economy have benefited immensely-indeed, one might even say immeasurably - from the growing presence of people of Asian origin in the U.S. labor force.

This Asian contribution to U.S. innovation and growth is not the result of "market forces." U.S. government policy barred Chinese immigration to the United States for over six decades, until the 1942 repeal of the Chinese Exclusion Act of 1882 permitted 105 Chinese to enter the United States annually. ${ }^{148}$ The National Quotas system, enacted in 1924, placed severe limits on Asian immigration to the United States until it was repealed in 1965. Meanwhile, Asian nations such as China, Philippines, India, Japan, South Korea, and Taiwan were making massive investments in their education systems, with the now more open United States benefiting from Asian "brain drain" from the last half of the 1960s. ${ }^{149}$ Responding to the U.S. high-tech lobby about its growing need for university-educated workers, Congress passed the Immigration Act of 1990, which over the ensuring decades welcomed hundreds of thousands if not millions of highly educated Asian students, non-immigrants, and immigrants to become participants in the U.S. advanced-technology ecosystem.

Unfortunately, the very processes of accessing higher education and work experience that enabled the inclusion of Asians as an over-represented minority in STEM employment functioned to exclude African Americans from these jobs. As we have detailed in our Fifty Years After project, Blacks as a group in the United States have been disadvantaged in their access to both the types of higher education and types of work experience required to achieve a significant improvement to their glaring under-representation among employees at leading U.S. technology companies. While many Blacks have succeeded as scientists and engineers at these companies, Blacks as a demographic group have not. As we have stressed in our project, an explanation of Black exclusion requires a perspective that comprehends the role of race in social structures that determine access to higher education and to work experience required for upward socioeconomic mobility in the $21^{\text {st }}$ century knowledge economy. The stark contrast between Asian Americans and African Americans in their participation in advanced tech employment accentuates the need for such a social analysis.

"Social networks" are integral to these social structures of education and experience in the building of careers. Within the United States, for example, Asian immigrant groups have formed social networks that accelerated their access to high-level jobs, particularly as science and

\footnotetext{
${ }^{148}$ Hsu, The Good Immigrants, ch. 4.

${ }^{149}$ Lazonick, Sustainable Prosperity, ch. 5.
} 
engineering professionals and particularly in Silicon Valley. ${ }^{150}$ The evidence on social networks, which we survey in this section of the paper, suggests that in the process of seeking to build their careers, even those African Americans who attain levels of higher education that could potentially result in access to professionals employment at leading tech companies have been unable or unwilling to participate in these social networks.

Concretely, social networks can influence hiring by providing employers and job candidates access to one another that may not be available through formal means, and by affecting the quantity and quality of the information each side receives about the other. ${ }^{151}$ A referral from someone already in the organization or known by relevant people in the organization is a recommendation containing richer information about the capabilities of a candidate and his or her potential fit with the job. Networks also give members information about job opportunities that may not appear in formal job listings. An employee referring a candidate he or she knows also has some stake in the success of that referral to the organization. Add to these advantages the well-documented phenomenon of homophily, referring to the preference of people to associate and work with people like themselves, in terms of age, race, ethnicity, gender and/or income. ${ }^{152}$

While the use of networks has substantial benefits for the people and companies inside the relevant networks, the problems for those not in the networks are clear. They are able to identify fewer opportunities, and the information conveyed to candidates about jobs and to employers about candidates is less certain and therefore more likely to be discounted. ${ }^{153}$ The evidence we discuss below suggests that network recruiting is widespread in the technology industry. Since white men and Asian men are the largest groups of jobholders in the technology industry and often come from similar elite institutions of higher education in the United States, we would expect them to dominate social networks relevant to gaining access to the best employment opportunities available at technology companies.

These social networks exclude groups such as Blacks and women from the highest-level jobs and result in a loss of potential talent and less cross-fertilization and familiarity among people of different groups. Networks generate and sustain inequalities. This outcome would be true even if there were no aversion to Blacks by whites nor stereotyping of Blacks' attributes by whites not familiar with them. Discrimination and stereotyping only makes the social networks of white and Asian males that much more exclusive.

From the perspective of the institutional disadvantages faced by Blacks in terms of access to higher education and work experience that we have considered thus far, we discuss what is known about the influence of social networks and discrimination, with a focus on the impact of

150 Saxenian, The New Argonauts.

151 The seminal works in sociology are Mark Granovetter, "The Strength of Weak Ties," American Journal of Sociology, 78, 6, 1973: 1360-1380; Mark Granovetter, Getting a Job: A Study of Contacts and Careers, Harvard University Press,1974.

152 Miller McPherson, Lynn Smith-Lovin, and James M Cook, "Birds of a Feather: Homophily in Social Networks", Annual Review of Sociology, 27, 2001: 415-444, has an extensive review of the academic literature on this concept. See also the discussion of "social closure" in Donald Tomaskovic-Devey and Kevin Stainback, "Discrimination and Desegregation: Equal Opportunity Progress in U.S. Private Sector Workplaces since the Civil Rights Act", Annals of the American Academy of Political and Social Science, 609, 2007: 56-58.

153 Roberto M. Fernandez and Roman Galperin, "Contemporary Perspectives on Organizational Social Networks," in Ajay Mehra, Daniel J. Brass, Daniel S. Halgin, Giuseppe Labianca, and Stephen P. Borgatti, eds., The Causal Status of Social Capital in Labor Markets, Emerald Group Publishing, 2014: 445-462. 
statistical discrimination on the low representation of African Americans in STEM employment. We argue that the exclusionary effect of networks and the possibility for stereotyping and statistical discrimination have been exacerbated by the decline of OEBM and the rise to dominance of NEBM among U.S. technology companies.

The available, but still limited, evidence supports the hypothesis that in the STEM fields, the vast majority of Blacks with higher-education credentials lack the social networks into such employment that whites and Asians have developed, while the potentially relevant networks that some highly educated Blacks have are less effective for obtaining STEM employment. ${ }^{154}$ There is a large empirical literature in sociology and economics on the racial exclusionary effects of networks. But almost all the empirical literature has analyzed the disadvantages networks pose for Blacks and Hispanics for entry-level and middle-skill jobs and not for advanced technology jobs. There is also a substantial body of research on the influence of social networks on wage disparities as well as occupational segregation between men and women. The literature on how networks can disadvantage women has investigated their access to managerial jobs, STEM occupations generally, and computer science jobs in particular. ${ }^{155}$

Social networks evolve through social processes that generate social connections and the information that these connections convey. Racial attitudes such as stereotyping and statistical discrimination can result from a lack of cross-network contact, as can different expectations of success and isolation at work among those outside the dominant social networks. ${ }^{156}$ In addition, unequal educational opportunity at all levels affects the networks available to different groups.

The empirical literature on the use of networks in recruiting and hiring in middle-skill and entrylevel jobs supports the hypothesis that networks do have negative effects on the employment opportunities of African Americans. ${ }^{157}$ Networks tend to be racially and ethnically homogeneous; networks contribute to job segregation through occupational sorting on the supply side and reducing the likelihood that minorities have a person within employing organizations to refer them for hire, while minorities that do have access to networks (referrals) within employing organizations fare better than non-referred minorities. Not every study finds that the use of networks pays off in terms of access to employment, but the majority do. ${ }^{158}$ While the empirical

154 William Julius Wilson makes this argument in the influential book, When Work Disappears, Knopf, 1999. The argument appears in many papers before and after Wilson's book. The following papers have good reviews of earlier literature: Roberto M. Fernandez and Isabel Fernandez-Mateo, "Networks, Race, and Hiring," American Sociological Review, 71, 1, 2006 : 4271; Steve McDonald, "Networks of Opportunity: Gender, Race, and Job Leads," Social Problems, 56, 3, 2009: 385-402; Marianne Bertrand and Esther Duflo, "Field Experiments on Discrimination," in Abhijit Banerjee and Esther Duflo, eds., Handbook of Field Experiments, J-Pal, 2016, at https://www.povertyactionlab.org/handbook-field-experiments.

155 For a review of the literature, see Trond Petersen, Ishak Saporta and Marc-David L. Seidel, "Offering a Job: Meritocracy and Social Networks," American Journal of Sociology, 106, 3, 2000: 763-816. See the discussion and references in Barbara F. Reskin and Denise D. Bielby, "A Sociological Perspective on Gender and Career Outcomes," Journal of Economic Perspectives, 19, 1, 2005: 71-86.

156 Beasley, Opting Out; Ciara Byrne, "This basic fact about social networks disadvantages minorities," Fast Company, September 5, 2018, at https://www.fastcompany.com/90220470/this-basic-fact-about-social-networks-disadvantagesminorities; Sam Levin, "Women say they quit Google because of racial discrimination: 'I was invisible'," The Guardian, August 18, 2017, at https://www.theguardian.com/technology/2017/aug/18/women-google-memo-racism-sexismdiscrimination-quit. This last article also discusses the case of Black technology workers.

157 Brian Rubineau and Roberto M. Fernandez, "Missing Links: Referrer Behavior and Job Segregation," Management Science, 59, 11, 2013: 2470-2489. Roberto M. Fernandez and Jason Greenberg, "Race, Network Hiring, and Statistical Discrimination," in Steve McDonald, ed., Networks, Work and Inequality, Emerald Group Publishing, 2013: 81-102.

158 Fernandez and Galperin, "Contemporary Perspectives on Organizational Social Networks." After reviewing numerous labor market studies and eleven case studies of hiring in particular firms, Fernandez and Galperin conclude: "With the exception of 
literature is much thinner, there have been some studies of how the use of networks disadvantages the employment opportunity of Blacks in technology employment. The relatively high rates of job mobility among employees of technology firms under NEBM increases the importance of networks for hiring and recruiting. ${ }^{159}$

Trond Petersen, Ishak Saporta and Marc-David Seidel study the effects of networks on employment outcomes by race, ethnicity, and gender with extensive data from a mid-sized technology company. ${ }^{160}$ They secured data on all 35,229 applicants to this company over a 10year period, 1985-1994. In this study, they measure the use of social networks in one's recruitment to the firm by whether the person was referred by a friend. There are very large differences between Blacks and whites; 80.3 percent of whites but only 4.9 percent of Blacks came through a friend's referral. Blacks made much greater use of campus recruiters and job ads. Referral by a friend had a significant effect on a person ending up with a job.

Petersen et al. argue that the causal chain is as follows: Referral or not has a strong influence on where and by whom the candidate receives the first interview. Those referred are much more likely to be interviewed in a setting closer to the people who are likely to make the decision about a job offer. People who are referred are much more likely to get a first interview in the placement office (where job assignments are made) or by an executive in the organization. Nonreferred candidates get their first interview on campus by a campus recruiter or in the human resource department. The first two advantages are much more likely to result in a second interview, and no one without a second interview receives a job offer. Referral by a friend results in whites receiving 73.0 percent of their first interviews in the placement department, and 8.7 percent with upper management. For Blacks, the figures are only 19.0 percent and 1.7 percent. Controlling for referral, the likelihood of receiving a first interview in any of the four places is the same. In addition, the likelihood of getting a second interview is the same for Blacks and whites after controlling for referral. The result of this process is that 10.0 percent of whites but only 4.5 percent of Blacks receive an offer.

Petersen et al. also find that if offered a job, Blacks and whites receive similar initial offers, but the size of the negotiated final salary is somewhat lower for Blacks. Finally, they find that among all Blacks who receive an offer, the percent who leave the organization after a year is much higher than it is for whites. They calculate that the probability of leaving after a year is over five times higher for Blacks than for whites. Controlling for referral, however, the departure rates are the same for Blacks and whites. Over time, the higher departure rate of Blacks exacerbates the skewed composition of the technology workforce. In sum, Blacks who have access to social networks, here proxied by a friend's referral, have the same likelihood of a job offer, the same

Fernandez and Fernandez-Mateo, "Networks, Race, and Hiring," employers in all of these case studies showed a preference for referrals during screening, even after controls were applied." Ibid., p. 448. There are also several case studies the show that both Blacks and Latinos who rely on personal networks within their own race or ethnicity often do more poorly than whites in finding jobs and in the wages paid on the jobs they find. See Luis M. Falcon, "Social Networks and Employment for Latinos, Blacks, and Whites," New England Journal of Public Policy, 11, 1, 1995: 17-28.

159 Bruce Fallick, Charles A. Fleischman and James B. Rebitzer, "Job-Hopping in Silicon Valley: Some Evidence Concerning the Microfoundations of a High-Technology Cluster," Review of Economics and Statistics, 88, 3, 2006: 472-481. Using data from the CPS supplements on job turnover, they find significantly higher rates of job mobility in Silicon Valley than in other metropolitan areas with substantial IT clusters, and higher rates of mobility in the computer industry than in other industries. See also Chris Benner, Work in the New Economy: Flexible Labor Markets in Silicon Valley, Wiley-Blackwell, 2002.

160 Petersen et al., "Offering a Job." 
salary offer, and the same probability of leaving after a year as whites. It is just that Blacks have dramatically lower access to this type of social network, as reported in this study. ${ }^{161}$

Educational experiences help form and influence the nature of networks that later affect employment opportunity in technology fields. The explanation given very frequently among Silicon Valley executives for the very low numbers of Black technology workers is that there are not enough qualified Blacks in the educational "pipeline." Data on who goes into and who leaves STEM majors support the argument that the limited pipeline is a significant problem. The pipeline argument, however, does not explain why so few potential Black technology workers are in the Silicon Valley pipeline.

Drawing on data developed in a 2017 Wired article, ${ }^{162}$ Julia Carrie Wong reports: "In 2014, Wired analyzed LinkedIn profiles to come up with a list of the top five feeder universities for Microsoft, IBM, Google, Apple, Yahoo, Facebook, and Twitter. The thirteen US universities included the elite private schools Stanford, Carnegie Mellon, and MIT, as well as public schools such as UC Berkeley and the University of Washington." She then adds: "One thing the schools had in common were student bodies with significantly fewer African-American students than the national average for four-year universities of $14 \%$. Stanford had the highest rate of black students, at 7.8\%." 163 A big part of the pipeline problem is that a relatively narrow band of elite schools, none of which has large Black enrollments, is predominantly where the pipeline for technology companies begins.

Exacerbating the problem is the fact that Blacks choose STEM fields as a major less often than do whites and Asians. Further, they attrite from STEM majors at a greater rate than whites. As for choice of major, we report two sources of data. Anthony Carnevale et al., using American Community Survey data, report that in 2016, only five percent of Computer Engineering majors and eight percent of Computer Science majors were African American. These low proportions stand in contrast to Health and Medical Administration majors and Psychology and Social Work majors, each of which was about 20 percent Black. ${ }^{164}$ The National Center for Educational Statistics reports the percentage of all degrees conferred that are STEM degrees by race. For Blacks it is 12 percent, while for whites it is 18 percent. The figures for Asians and Hispanics are 33 percent and 15 percent, respectively. ${ }^{165}$

Blacks leave STEM majors at a higher rate than whites, but the difference is not enormous. A report from the National Center for Educational Statistics using a special longitudinal data set of students who began postsecondary education in 2003-04 shows that 36 percent of Black students

161 We should note that their results are cross-sectional associations. There may be differences among those referred and those who do not that affect the outcomes but are not measured in these data.

162 Joanna Perlstein, “The Schools Where Apple, Google, and Facebook Get Their Recruits," Wired, May 22, 2014, at https://www.wired.com/2014/05/alumni-network-2/.

163 Julia Carrie Wong, "Segregated Valley: the ugly truth about Google and diversity in tech", The Guardian, August 7, 2017, at https://www.theguardian.com/technology/2017/aug/07/silicon-valley-google-diversity-black-women-workers.

164 Anthony Carnevale. Megan Fasules, Andrea Porter, Jennifer Landis-Santos, "African Americans: College Majors and Earnings," Georgetown University Center on Education and the Workforce, 2016, Appendix: pp. 6-7, at https://1gyhoq479ufd3yna29x7ubjn-wpengine.netdna-ssl.com/wp-content/uploads/AfricanAmericanMajors_2016_web.pdf.

165 National Center for Educational Statistics, Table 306.20.Total fall enrollment in degree-granting postsecondary institutions, by level and control of institution and race/ethnicity of student: Selected years, 1976 through 2014, at https://nces.ed.gov/programs/digest/d15/tables/dt15 306.20.asp? current=yes. 
switched out of STEM majors, compared to 30 percent of white students. ${ }^{166}$ When the probability of attrition is analyzed with a multivariate model controlling for the education of parents, income, high-school mathematics courses, high-school GPA, and mathematics courses taken in the first year of post-secondary education, the effect of being Black is not statistically significant. ${ }^{167}$ These results support and amplify our discussion of the impact of educational disparities at the pre-college level.

Maya Beasley conducted two studies that shed light on why Blacks do not choose STEM majors as often as whites and why they leave STEM majors at a higher rate. Her book, Opting Out: Losing the Potential of America's Young Black Elite, reports on an in-depth qualitative study of 30 Black and 30 white college juniors, with the sample split between Stanford University and the University of California Berkeley. The sample is evenly divided between Blacks and whites at each campus. ${ }^{168}$ While acknowledging the large differences in high-school resources and the important effects of educational and residential segregation, Beasley concentrates her study on the psychological and social factors that influence Black versus white attitudes about how welcome and how isolated they might be in STEM versus other fields, and how they carry the legacy of economic and social segregation in shaping their career decisions. ${ }^{169}$

Pamela Bennett, in a review of Opting Out, aptly summarizes Beasley's argument:

... African- American students in her study opted for less prestigious and less lucrative occupations because of constraints on their social capital that directly emerge from racially segregated social networks (which, themselves, emerge from residential and school segregation), a desire to avoid experiences with discrimination in occupations dominated by whites, and a desire to enter occupations where they could put their degrees to work to improve the lives of other blacks. All of these factors lead AfricanAmerican students at elite schools to enter occupations in which African-Americans are already well represented. ${ }^{170}$

As a result, the Black students were more likely to choose non-profit work, civil rights law, and government work that focused on social goals relevant to Black communities. Beasley also highlights a phenomenon that she labels "stereotype threat," which refers to fears that they might reinforce the stereotype that Blacks are not as smart as whites, or that they will underperform on the job in STEM fields. She further reports that social networks were segregated, in part through self-selection, and as a result, Black students were less exposed to knowledge about whitedominated professions and their fears about racism and racial isolation were reinforced. In an interview about her book, Beasley notes that the rise of Black-themed dorms and Black clubs have contributed to the racial segregation of social networks. ${ }^{171}$

\footnotetext{
166 Xianglei Chen and Matthew Solder, “STEM Attrition: College Students' Paths Into and Out of STEM Fields,” National Center for Educational Statistics, 2013, Table 2, at https://nces.ed.gov/pubs2014/2014001rev.pdf.

167 Chen and Solder, "STEM Attrition," Table 5.

168 Maya A. Beasley, Opting Out: Losing the Potential of America's Young Black Elite, University of Chicago Press, 2011

169 See Pamela R. Bennett, "Book Review of Opting Out," American Journal of Sociology, 118, 6, 2013: 1731-1733; Susan E. Chase, "Book Review of Opting Out," The Review of Higher Education, 36, 3, 2013: 408-409; Allie Grasgreen, "Outing Out," InSide Higher Ed, December 2, 2011.

170 Bennett, "Book Review of Opting Out," p. 1731

171 Grasgreen, "Opting Out.”
} 
Beasley extends and strengthens the findings from her book in an article co-authored with Mary Fischer, "Why They Leave." 172 They estimate the effect of a measure of "group performance anxiety," using data from the National Longitudinal Study of Freshman. ${ }^{173}$ They argue that most research on the relatively lower numbers of Black STEM majors and relatively higher rates of attrition for these majors has focused on academic deficits as the explanation. As Beasley and Fischer explain:

Our primary measure of stereotype threat is what we call group based performance anxiety, which is derived from a series of questions from the third wave about race and/or gender self-consciousness and the extent to which students feel that their individual performance reflects upon their group. Items include student's agreement on three statements: "if I excel academically it reflects positively on my group", "if I do poorly academically it reflects negatively on my group", and "if I don't do well people will look down on others like me."...We also control for what we call general performance anxiety: the extent to which students feel pressure or anxiety unrelated to their group identity to perform academically. Because stereotype threat is sometimes confused with a more general anxiety, it is particularly important to include this as a separate variable. This measure is based on two questions: the extent to which a student agrees that if his/her instructor knows s/he is having difficulty with class they will think less of the student and the extent to which the student believes fellow students will think less of him/her if they know s/he is having difficulty with class. ${ }^{174}$

Beasley and Fischer then analyze the incidence of this measure across gender and race groups and its effect on the likelihood that the students who start in a STEM field decide to leave that major. The study from the National Center for Education Statistics reviewed above shows that academic deficits are an important part of the explanation. Our review of the large gap in educational resources available to Blacks compared to whites is strong corroborating evidence. ${ }^{175}$ Beasley and Fischer do not, however, view academic deficits as the whole story. Nor is interest in the STEM field. They cite a 2007 National Science Foundation report that indicates that 19 percent of graduates from Historically Black Colleges and Universities were in STEM fields. The rates for whites and Asians were 17 percent and 30 percent, respectively, at all institutions. ${ }^{176}$

Beasley and Fischer find that Blacks attrite from STEM at a higher rate than whites, who also attrite at a higher rate than Asians. With regard to anxiety measures and their effects, they find that Blacks as well as other minorities experience group performance anxiety (stereotype threat) significantly more than whites and, further, group performance anxiety has a statistically significant effect on leaving STEM majors.

\footnotetext{
172 Maya Beasley and Mary Fischer, "Why They Leave: The Impact of Stereotype Threat on the Attrition of Women and Minorities from Science, Math and Engineering Majors," Social Psychology Education 15, 4. 2012: 427-448.

173 Ibid., p. 435. The survey is described at https://nlsf.princeton.edu/. The survey was designed to gather information on attitudes, expectations, perceptions and motivations.

174 Ibid., p. 436.

175 Moss et al., Employment and Earnings of African Americans."

176 National Science Foundation, Division of Science Resources Statistics S\&E degrees, by Race/Ethnicity of Recipients: 19952004, No NSF 07-308 2007, at https://www.nsf.gov/statistics/degreerecipients/
} 
Despite all the problems Blacks face in getting access to employment in high technology, both Beasley ${ }^{177}$ and Wong ${ }^{178}$ argue that there is still a much greater number of educationally qualified Black candidates who are working in high technology in other areas of the United States than in Silicon Valley (which is consistent with EEOC data that we presented toward the beginning of this paper). Beasley presents 2016 data from the Census Bureau's American Community Survey that show that Silicon Valley is very different than other metropolitan areas with large concentrations of high technology employment. "Silicon Valley's tech workforce is 2.2 percent black and 4.7 percent Hispanic. In comparison, Houston's metropolitan area tech workforce is 11.9 percent black and 12.6 percent Hispanic, and the New York metropolitan area's tech workforce is 7.3 percent black and 9.6 percent Hispanic. The Atlanta and Washington, D.C., metropolitan areas both have large numbers and proportions of black tech employees-20.6 percent and 17.1 percent, respectively. Miami and Los Angeles are each comprised of a high number and proportion of Hispanic workers as well, at 29.9 percent and 12.7 percent. All of these metropolitan areas employ 1.5 times to 3.3 times the number of black and Hispanic tech workers as Silicon Valley."179

In discussing Silicon Valley's high-profile issue with diversity, Wong amplifies the contrast between Washington D.C. and Silicon Valley. She interviewed William Spriggs, an economist at Howard University who has been the chief economist at the EEOC as well as at the AFL-CIO.

Spriggs argued that a significant difference is that in DC, the tech industry grew up around the federal government. Affirmative action provisions for federal contracting encouraged African Americans to start businesses in computing or data processing in the late 1970s and early 1980s. The first domain name registrar for the internet, for example, was the black-owned company, Network Solutions, which was founded in northern Virginia in 1979. "Having black-owned companies helped get people in," Spriggs said. "It's partly entrepreneurship, partly because the federal government does not discriminate, partly because you have to have [security] clearance, which favors American citizens, and partly because the area is heavily black." Schools in the region focused on preparing their students for technology jobs with government contractors as well. ${ }^{180}$

She also reports on an interview with Ben Jealous, former president of the NAACP, who was a partner at venture capital firm, Kapor Capital. Jealous observed:

The industry [in Washington D.C.] has been reaching out to and working with the historically black colleges and universities in the area, Morgan State, Virginia State, the University of Baltimore Maryland - all of those schools are Stem (sic) schools that have focused on providing people to legacy tech companies. The relationships are advanced enough that companies will inform universities what kind of skills they

\footnotetext{
177 Maya Beasley, “There Is a Supply of Diverse Workers in Tech, So Why Is Silicon Valley So Lacking in Diversity?” Center for American Progress, 2017, at https://cdn.americanprogress.org/content/uploads/2017/03/28141805/TechDiversityreport3.pdf.

178 Wong, "Segregated Valley."

179 Beasley, "There Is a Supply of Diverse Workers in Tech," p.2.

180 Wong, "Segregated Valley."
} 
project needing five-years out, so that curricula can be adapted to ensure a trained workforce." 181

That employment opportunity for Black technology workers in Washington D.C. is significantly better than it is in other technology hubs and dramatically better than it is in Silicon Valley accords with our discussion of government employment in Working Paper \#4. ${ }^{182}$ As we showed, government agencies have always been a more advantageous employer for Blacks than business enterprises. As Spriggs notes, the technology sector in Washington D.C. grew with the government as a major client, helping to explain the success of Blacks in this geographical area.

Drawing on data from the National Science Foundation, ${ }^{183}$ Beasley states: "In 2013, there were 262,981 Americans of color ages 45 years and younger with bachelor's or advanced degrees in computer and mathematical sciences, as well as electrical engineering-just three of several fields closely associated with high tech jobs. These individuals represent 18.8 percent of degree holders." 184 She also reports, however, that "of the people of color with degrees in these fields, 7 percent of men and 12 percent of women were unemployed compared with 2 percent of white men. An additional 13 percent of men and 16 percent of women of color worked in jobs unrelated to their degrees relative to only 7 percent of white men." 185

The evidence that Beasley and Wong provide suggests that the oft-used argument among Silicon Valley executives of a lack of qualified people of color in the educational pipeline is far too simple an explanation for Silicon Valley's poor performance in employing Black technology workers. As we discussed earlier, the large educational disparities in public schools as well as the experience of Blacks at many selective colleges has certainly created a formidable set of obstacles for increasing the proportion of Blacks in the technology workforce in the future. Yet technology regions in which Blacks have developed superior social networks do better at employing Blacks than does Silicon Valley. There appear to be a large number of underutilized or at least under-recruited educationally qualified potential African American employees available to Silicon Valley.

Why does Silicon Valley, the world's leading technology district, have a particular problem employing Blacks? We think that the answer lies in the hypermobility of labor that has become a hallmark of Silicon Valley-where the transient employment relations characteristic of NEBM emerged and developed most fully ${ }^{186}$ - more than in other districts in the United States. This hypermobility stems from the attraction to Silicon Valley of highly capable personnel to work at some of the world's most successful tech companies and the history of start-ups in the district competing for their labor. Given the quality of labor that firms in Silicon Valley can attract, Blacks as a group are particularly disadvantaged in gaining employment as professionals there because of inferior education. The hypermobility of tech personnel moving from one firm to another exacerbates this disadvantage by making social networks all the more important for the

\footnotetext{
${ }^{181}$ Ibid.

${ }^{182}$ Lazonick et al., "The Unmaking of the Black Blue-Collar Middle Class."

${ }^{183}$ National Science Foundation, "Scientists and Engineers Statistical Data System," at https://sestat.nsf.gov/sestat/sestat.html.

${ }^{184}$ Beasley, "There Is a Supply of Diverse Workers in Tech," p. 4.

${ }^{185}$ Ibid., p. 4 and Figure 2.

${ }^{186}$ Lazonick, Sustainable Prosperity.
} 
pursuit of a technology career, with Blacks being disadvantaged compared with whites and Asians in accessing and participating in these networks.

In addition, the hypermobility of labor that has come to characterize employment in Silicon Valley has undermined the application of Equal Employment Opportunity remedies against discrimination on the basis of race. When it was launched in 1966, the work of the Equal Employment Opportunity Commission, focused on discrimination in pay and promotion within a business enterprise. It was not designed to deal with discrimination across firms as people use the labor market rather internal employment structures to advance their careers.

While discrimination suits are still filed against Silicon Valley companies, ${ }^{187}$ they are rare. A primary means from 1965 to 1980 of increasing minority and female employment in companies was through the filing of discrimination cases with the Office of Civil Rights in the U.S. Department of Justice or Equal Employment Opportunity Commission. Further, any organization or government agency that received federal funding of any kind and was deemed to have minority or female representation below the availability of the relevant groups, had to develop an affirmative-action plan and was subject to affirmative-action review under Executive Order 11246, signed by Lyndon Johnson in 1965.

Many writers and researchers have documented the decline of federal EEO enforcement since the 1980s. The history of the rise and fall of affirmative action as well as the legal and political issues involved are very large subjects with an enormous literature on each. Here we concentrate on three points most relevant to our larger story. Affirmative action increased minority and female employment and had a lasting effect in companies even after affirmative-action review ended. Serious enforcement of affirmative action was drastically curtailed by the Reagan administration from 1980 on, as was the enforcement of anti-discrimination law more generally. Largely ineffective diversity programs voluntarily initiated by companies and other organizations themselves replaced the government regulatory effort to increase minority and female employment. Supporting this view are our findings, discussed earlier in this paper, on the higher proportional representation of Blacks among professionals at "Old Economy" IBM and HewlettPackard compared with "New Economy" companies such as Alphabet, Amazon, Apple, Cisco, Intel, and Microsoft.

There exist a number of very useful reviews of the history of affirmative-action policy and its impacts. ${ }^{188}$ The consensus of the research is that affirmative action and federal enforcement of anti-discrimination legislation more generally has had a positive effect on Black employment. Recent research from Fidan Kurtulus using EEO-1 data from 1978 to 2003 has shown that firms under contract with the federal government (and hence subject to affirmative-action review)

187 Sam Levin, "US government v Silicon Valley: Oracle said to owe \$400m to women and minorities," The Guardian, January 23, 2019.

188 Donald Tomaskovic-Devey, "Written Testimony of Donald Tomaskovic-Devey," Equal Employment Opportunity Commission, July 2015, at https://www.eeoc.gov/eeoc/meetings/7-1-15/devey.cfm; Fidan Ana Kurtulus, "The Impact of Affirmative Action on the Employment of Minorities and Women: A Longitudinal Analysis Using Three Decades of EEO-1 Filings," Journal of Policy Analysis and Management, 35, 1, 2016: 34-66; Jonathan S. Leonard, "The Impact of Affirmative Action on Employment," Journal of Labor Economics, 2, 4 1984: 439-463; Jonathan S. Leonard, "The Impact of Affirmative Action Regulation and Equal Employment Law on Black Employment," Journal of Economic Perspectives, 4, 4, 1990: 4763; Conrad Miller, "The Persistent Effect of Temporary Affirmative Action," American Economic Journal: Applied Economics, 9, 3 2017: 152-190 (a very useful source, with a full list of references). 
increased their employment of minorities and women during the period the organization was under contract with the government. ${ }^{189}$ She finds that the gain persists for a few years after the contract ends, but then dissipates. Conrad Miller also uses EEO-1 data, from 1978 to 2004, and extends Kurtulus's work with a more complete model of how contractor status affects the Black share of employment. His results indicate that the growth of Black employment in firms under a federal contact is substantial-larger than the estimated effects Kurtulus finds. Importantly, he also finds that the rate of increase in Black share continues at a similar rate even after the contract, and therefore regulation, has ended for as long a time as the data can show, up to 7-9 years for some firms in the data set. The initial increase in Black employment apparently induced new recruiting and screening methods and created a climate as well as an increased presence of Black employees, all of which were conducive to continued growth in Black employment.

The advent of the Reagan administration in 1981 and the appointment of Clarence Thomas as head of the EEOC the following year effectively ground affirmative action to a halt. ${ }^{190}$ Lynn Burbridge provides data on the change in budgets, cases filed, investigated, and judgments made at the EEOC and the Office of Federal Contract Compliance that show the steep decline in activity under Thomas. ${ }^{191}$ A report by the Government Accounting Office in 1988 concluded:

Of the charges closed with no-cause determinations by the 11 EEOC district offices and state agencies from January to March 1987, critical evidence was not verified in 40 to 87 percent of charge investigations. Relevant witnesses were not interviewed in at least 20 percent of charge investigations in 7 of the 11 offices, and charging parties were not compared with similarly situated employees in at least 20 percent of charge investigations in 5 of the 11 offices. EEOC accepted all of the charge investigations that GAO reviewed, but GAO identified many cases with serious deficiencies, ranging from 40 percent in one state to 87 percent in another. EEOC officials told GAO that EEOC did not have enough staff to monitor the agencies effectively. Under the current investigative approach, charges filed were not fully investigated; yet the size of the backlog nearly doubled between 1983 and 1987. At the end of fiscal year 1987, more than 118,000 charges filed were awaiting an investigation by either EEOC or the state agencies....The current EEOC Chairman disagreed that major changes are needed. ${ }^{192}$

Jonathan Leonard also provides convincing evidence that the positive effects of affirmative action that were detected in the previous fifteen years disappeared as well, although other demographic changes in the workforce occurred during the mid-1980s as well that aversely influenced Black employment. ${ }^{193}$

189 Kurtulus, "The Impact of Affirmative Action."

190 Leonard, "The Impact of Affirmative Action Regulation"; Erin Kelly, and Frank Dobbin, "How Affirmative Action Became Diversity Management," American Behavioral Scientist; 41, 7, 1998: 960-984; William M. Welch, "Thomas presided over shift in policy at EEOC, records show," AP News, July 25, 1991, at https://apnews.com/article/b419883e871b5117649d1f3fdacf6f95. See also Tomaskovic-Devey, "Written Testimony." Tomaskovic-Devey provides an extensive set of references on the changes in policy.

191 Lynn C. Burbridge, "Changes in Equal Employment Enforcement: What Enforcement Statistics Tell Us," Review of Black Political Economy, 15, 1, 1986: 71-80.

192 U.S. General Accounting Office, "Equal Employment Opportunity: EEOC and State Agencies Did Not Fully Investigate Discrimination Charges," General Accounting Office, Human Resource Division, GAO/HRD-89-11, October 1988: 3-4, at https://www.gao.gov/assets/hrd-89-11.pdf.

193 Leonard, "The Impact of Affirmative Action Regulation," p. 58. 
Affirmative action was also actively in place in college admissions in the 1970s, and in the 1978 Bakke case the Supreme Court legitimized the use of race as a criterion for admission. As with affirmative-action policy with regard to employment, the 1980s saw increasing backlash. The focus of controversy over affirmative action in college admissions grew through the 1990s, and in 1996, California passed Proposition 209, which banned affirmative action in educational institutions. ${ }^{194}$ Similar laws have passed in a host of other states, ${ }^{195}$ and eight states have banned affirmative action in public universities. ${ }^{196}$ The issue has come to private colleges and universities now with the very high profile suit against Harvard University claiming that Harvard unfairly discriminates against Asian Americans in admissions. ${ }^{197}$ In the case of Asian Americans, the problem is that, as a group, they have been highly successful in gaining admission to an elite university such as Harvard, so that the charge of discrimination is for actions of the University in implementing admission criteria aimed at limiting that success. Of course, the problem for African Americans in gaining access to high-quality education is just the opposite.

The dismantling of affirmative action as well as the use of race-based criteria for college admissions more generally has two important implications for our analysis. First, it adversely affected the access of Blacks to selective colleges, and hence the capabilities and networks that Blacks could build to pursue technology careers. Second, there was a marked reduction in the legal, political, and social pressures on technology companies in Silicon Valley and elsewhere to take serious action to increase the employment of Black technology workers.

From the late 1980s on, the structures and activities that most companies had put in place to advance affirmative-action goals withered, and a new set of activities replaced them. Diversity management is the label that describes these new activities. Erin Kelly and Frank Dobbin, who have described this evolution in detail, ${ }^{198}$ provide this summary:

EEO and AA offices and activities survived, we argue, because EEO/AA specialists did not respond passively to Reagan's cutbacks in enforcement. At first, they touted the efficiency of formalizing human resources management through such antidiscrimination measures as grievance procedures, formal hiring and promotion systems, and systematic recruitment schemes. Later, they invented the discipline of diversity management, arguing that the capacity to manage a diverse workforce well would be the key to business success in the future. Over the space of a quarter of a century, efforts to integrate the workforce were transformed, in management rhetoric, from an onerous requirement of federal law to a valuable means to increasing organizational effectiveness. The novel employment practices that survived the waxing and waning of

194 Hua Hsu, "The rise and fall of affirmative action" The New Yorker, October 8, 2018.

195 Ibid. Hsu reports: "The effect on the enrollment of people of color was immediate. Between 1995 and 1998, offers of admission to African-Americans at Berkeley and U.C.L.A. declined by fifty-five per cent."

196 Halley Potter, "What Can We Learn from States That Ban Affirmative Action?" The Century Foundation, 2014, at https://tcf.org/content/commentary/what-can-we-learn-from-states-that-ban-affirmative-action/.

197 See, for example, Anemona Hartocollis ,"The Harvard Bias Suit by Asian-Americans: 5 Key Issues” New York Times, December 20, 2018, at https://www.nytimes.com/2018/12/20/us/harvard-asian-american-students-discrimination.html; Adam Liptak and Anemona Hartocollis, "Supreme Court will hear challenge to affirmative action at Harvard and U.N.C,", New York Times, January 24, 2022, at https://www.nytimes.com/2022/01/24/us/politics/supreme-court-affirmative-action-harvardunc.html.

198 Kelly and Dobbin, "How Affirmative Action Became Diversity Management." 
EEO and AA law, however, are those that have been least effective at changing the gender and racial mix of the workforce. ${ }^{199}$

Based on her review of qualitative and quantitative evidence from her own research and others, Sharon Collins also sums up the evolution from affirmative action to diversity management:

...diversity can be viewed as a rubric for a set of activities meant to symbolize corporate "good will" without meaningful change. In this case the role it plays may forestall meaningful change in the corporate culture; the use of diversity as an organizing concept for resource development would be to obscure underlying bias against race based (primarily black-oriented) private sector employment policies. ${ }^{200}$

Diversity initiatives abound in Silicon Valley, and concerns with the lack of diversity in the big companies such as Alphabet and Facebook (now known as Meta) have made a lot of news. One of the most frequently used diversity initiatives involves diversity training of managers and employees by diversity consultants. Diversity training now is a large and booming industry. A new popular form of training stresses that bias is "unconscious," which as Beasley and others have noted renders bias "blameless." 201 Other initiatives that have been used, although less frequently, include targeted recruiting and hiring, the creation of diversity councils or taskforces with a diverse group of managers within the firm, hiring a diversity manager, and setting diversity hiring goals. ${ }^{202}$

With Alexandra Kalev and others, Dobbin has written a number of influential papers analyzing different diversity-increasing efforts at a random sample of companies drawn from EEO-1 files from 1971 to 2001, accessed through an Intergovernmental Personnel Act agreement with EEOC. They added a survey to determine the diversity initiatives adopted by these firms over this period. ${ }^{203}$ They find that mandatory diversity training has no immediate effect and for some groups, it makes matters worse after five years. Grievance procedures often result in retaliation. Programs that become part of a business's practices do produce results. These include involving managers in the design of diversity plans, funding these plans and implementing them through internal diversity councils or taskforces, establishing recruiting goals and conducting targeted recruiting generally and particularly at predominantly Black campuses, institutionalized mentoring, and hiring diversity managers. ${ }^{204}$ They also found that affirmative action and the diversity plans and goals mandated by affirmative action produced clear employment gains for minorities and women, confirming the other studies of the positive effects of affirmative

\footnotetext{
199 Ibid., p. 966.

${ }^{200}$ Sharon M. Collins, "Diversity in the Post Affirmative Action Labor Market: A Proxy for Racial Progress?" Critical Sociology, 37, 5, 2011: 521-540.

201 Beasley, "There Is a Supply of Diverse Workers in Tech."

202 Ibid., pp. 5-6, Donald Tomaskovic-Devey, "Written Testimony"; Frank Dobbin and Alexandra Kalev, "Why Diversity Programs Fail," Harvard Business Review, 94, 7, 2016: 52-60.

${ }^{203}$ Frank Dobbin and Alexandra Kalev, "The Architecture of Inclusion: Evidence from Corporate Diversity Programs," Harvard Journal of Law \& Gender, 30, 2, 2007: 279-301; Alexandra Kalev, Frank Dobbin, and Erin Kelly, "Best Practices or Best Guesses? Assessing the Efficacy of Corporate Affirmative Action and Diversity Policies," American Sociological Review, 71, 4, 2006: 589-617; Frank Dobbin, Daniel Schrage, and Alexandra Kalev, "Rage Against the Iron Cage: The Varied Effects of Bureaucratic Personnel Reforms on Diversity,” American Sociological Review, 80, 5, 2015: 1014-1044; Dobbin and Kalev, "Why Diversity Programs Fail."

204 Dobbin and Kalev, "Why Diversity Programs Fail."
} 
action. $^{205}$ Donald Tomaskovic-Devey observes that "internally, the most efficacious organizational practice [for diversity management] seems to be simply creating organizational responsibility roles and structures to monitor human resource outcomes."206

Employees of Silicon Valley companies have made many charges of racist treatment and discrimination in decisions made within their companies. Pending lawsuits and claims to the EEOC alleging discrimination in hiring and pay support the contention that, in addition to educational disparities, social networks and the elimination of formal affirmative action, discrimination is part of the explanation for the low numbers of Black technology workers in Silicon Valley. ${ }^{207}$ There is a large body of research on the existence and impacts of discrimination in hiring, pay, and promotion. Tomaskovic-Devey and Kevin Stainback ${ }^{208}$ as well as Marianne Bertrand and Esther Duflo ${ }^{209}$ offer explanations of the different types of employment discrimination, the attempts to measure each, and what the evidence appears to show about their prevalence. Together, these papers provide a picture of the existing research on employment discrimination. It appears that the type of systematic research reviewed by these authors has not been done, however, for the relevant occupations in Silicon Valley that are our concern.

An important distinction in these studies is between, on the one hand, overt prejudice and bias in hiring, pay, and promotion and, on the other hand, statistical discrimination that involves the use of alleged or actual group attributes to rationalize inequitable treatment of individuals with these attributes. The concept of statistical discrimination, which grew out of the economics of information literature, posits that employers cannot fully predict a candidate's likely productivity. To reduce the costs of screening that might reveal more about the candidate's likely productivity, employers might assign the group's average characteristics rather than trying to determine these characteristics for individual candidates. Even if there are plenty of Black candidates who meet the employer's threshold, if Blacks have a lower average value for the relevant attributes an employer is looking for, or their values have more variance and hence uncertainty, the employer might still choose white candidates instead of qualified Black candidates. It is not a far jump to say that employers might not really know anything about averages or variances, but they have exposure to stereotypes, including unfounded ones, and act on those stereotypes. This is the argument Blacks and women often make about their experiences with recruiting, hiring, promotion, and general treatment at the workplace in Silicon Valley.

Bertrand and Duflo provide an extensive explanation and survey of the literature on statistical discrimination. ${ }^{210}$ Devah Pager argues that the likelihood of statistical discrimination should be highest in deciding whom to interview and whom to hire, rather than in pay and promotion,

205 Kalev et al., "Best Practices or Best Guesses?"

206 Tomaskovic-Devey "Written Testimony." See also Megan Rose Dickey, "The Future of Diversity and Inclusion in Tech," TechCrunch.com, June 17, 2019, at https://techcrunch.com/2019/06/17/the-future-of-diversity-and-inclusion-in-tech/; Allison Scott, Freada Kapor Klein, and Uriridiakoghene Onovakpuri, “Tech Leavers Study,” Kapor Center for Social Impact, 2017, at https://www.kaporcenter.org/wp-content/uploads/2017/08/TechLeavers2017.pdf.

207 Angwin and Castaneda, "Digital Divide," provide examples of both from the late 1990s. They also report that at least a dozen Silicon Valley companies with federal contracts were cited for violations of the affirmative action plans they had established as part of receiving the contracts. The recently settled lawsuit against Uber and the Labor Department's suit again Oracle indicate that the problem still very much exists.

208 Tomaskovic-Devey and Stainback, "Discrimination and Desegregation."

209 Bertrand and Duflo, "Field Experiments on Discrimination."

210 Ibid. 
because information about candidates is thinnest at that point. ${ }^{211}$ Recall that Petersen et al. found minorities were more likely to receive initial interviews under less favorable circumstances, with an adverse effect on the chance of a job offer. ${ }^{212}$

Pager, ${ }^{213}$ Pager and Western, ${ }^{214}$ Quillian et al., ${ }^{215}$ and Bertrand and Duflo ${ }^{216}$ argue strongly that the most reliable evidence on the existence of discrimination comes from field experiments. Each of these papers describes how the field experiments have been carried out. They note the criticisms of experimental evidence on discrimination, raised most ardently by James Heckman, but they assert that the consistency of the experimental evidence gives confidence in the results. ${ }^{217}$ Pager, Pager and Western, and Quillian et al. report that, while non-experimental evidence shows a decline and apparent elimination of discrimination based solely on race, experimental evidence consistently does not. A meta-analysis of evidence from all existing field experiments indicates that racial hiring discrimination still exists and has not diminished significantly from 1989 to the present. ${ }^{218}$ Quillian et al. put it as follows:

Since 1989, whites receive on average 36\% more callbacks than African Americans, and $24 \%$ more callbacks than Latinos. We observe no change in the level of hiring discrimination against African Americans over the past 25 years, although we find modest evidence of a decline in discrimination against Latinos. Accounting for applicant education, applicant gender, study method, occupational groups, and local labor market conditions does little to alter this result. Contrary to claims of declining discrimination in American society, our estimates suggest that levels of discrimination remain largely unchanged, at least at the point of hire.

It is difficult to measure the motivations for discrimination and therefore difficult to isolate the practice of statistical discrimination as opposed to discrimination based on prejudice, aversion, or animus. Qualitative evidence indicates that white employers openly express negative stereotypes of non-whites. ${ }^{219}$ Connecting the expression of stereotypes to actual hiring decisions is very difficult. Duflo and Bertrand offer some experimental evidence for the existence of statistical discrimination, however. ${ }^{220}$ Bertrand and Mullainathan's well-known experiments on callbacks for mailed resumes with names that suggest different race groups found lower rates of callbacks for Black-seeming resumes, and, while the white call back rate increased with stronger qualifications on the resume, the rate did not for Blacks. ${ }^{221}$ In replicating these results, John Nunley and co-authors also saw a lower call back rate for resumes that suggested a Black

211 Devah Pager, "The Use of Field Experiments for Studies of Employment Discrimination: Contributions, Critiques, and Directions for the Future," Annals of the American Academy of Political and Social Sciences, 609, 2007: 104-133.

212 Petersen et al. "Offering a Job."

213 Pager, "The Use of Field Experiments."

214 Devah Pager and Bruce Western, "Identifying Discrimination at Work: The Use of Field Experiments," Journal of Social Issues, 68, 2, 2012: 221-227.

215 Lincoln Quillian, Devah Pager, Ole Hexel, and Arnfinn H. Midtbøen, "Meta-analysis of Field Experiments Shows No Change in Racial Discrimination in Hiring over Time," Proceedings of the National Academy of Sciences, 2017: 1-6

216 Bertrand and Duflo, "Field Experiments on Discrimination."

217 James J. Heckman, "Detecting Discrimination”, Journal of Economic Perspectives, 12, 2, 1998: 101-116.

218 Quillian et al., "Meta-analysis of Field Experiments."

219 See Philip Moss and Chris Tilley, Stories Employers Tell: Race and Hiring in America, Russell Sage, 2001, for evidence and a review of other literature.

220 Bertrand and Duflo, "Field Experiments on Discrimination," p. 17.

221 Marianne Bertrand and Sendhil Mullainathan, "Are Emily and Greg More Employable Than Lakisha and Jamal? A Field Experiment on Labor Market Discrimination," American Economic Review, 94, 4, 2004: 991-1013. 
candidate. ${ }^{222}$ This study was of college graduates, and is the only one of the experimental studies reviewed that focuses on individuals who might be comparable to job applicants in Silicon Valley. It is significant that it corroborates the evidence from studies of potential applicants in non-college jobs.

Duflo and Bertrand also discuss experimental evidence from psychologists that shows how stereotype threat in simulated-interview and test-taking situations negatively affects minority performance. ${ }^{23}$ This finding brings us back to Beasley's work that gives evidence that this type of threat affects minority students' choice of and decision to leave STEM college majors. Such behaviors can become self-fulfilling prophecies. $^{224}$

Fernandez claims that evidence for statistical discrimination comes from employers' preferred use of network-based referrals for hiring decisions. ${ }^{225} \mathrm{He}$ argues that in Silicon Valley, referral and network-based hiring reduces uncertainty associated with less "familiar" candidates, such as Blacks, and therefore is a form of statistical discrimination. He found that employers overwhelmingly preferred to hire based on referrals. As he sums up his findings:

We find that employers in this setting are making use of the cheap information available to them: Consistent with statistical discrimination theory, minority referrals are more likely to receive a job offer than non-referred minority applicants are, and are not disfavored relative to referred whites. ${ }^{226}$

This finding connects with the problems of deficient social networks and homophily with which we began this discussion of why even qualified Blacks may lack equal access to high-technology employment opportunities. Various social processes, including uncertainty about an individual's qualifications, falling back on stereotypes, and the importance of an individual's involvement in social networks, can interact in practice to create formidable, although almost invisible, barriers to equal employment opportunity to even the best-educated Blacks.

\section{The equal employment opportunity omission}

Within the context of the transition from the OEBM to the NEBM that we have emphasized in our Fifty Years After project, our discussions of social networks, the decline of equal employment enforcement, and the rise of diversity management, and evidence of continued statistical discrimination, add to our understanding of the under-representation of Blacks in the U.S. tech sector. Policies suggested by Beasley and Tomaskovic-Devey, ${ }^{227}$ which are similar to ones that have worked in the past when motivated by political action and regulatory change, offer some guidance for making the situation better. But, as we will argue in the forthcoming conclusion of the Fifty Years After project, without fundamental changes in the business models,

\footnotetext{
222 John M. Nunley, Adam Pugh, Nicholas Romero, and R. Alan Seals, "Racial Discrimination in the Labor Market for Recent College Graduates: Evidence from a Field Experiment," The B.E. Journal of Economic Analysis \& Policy, 15, 3, 2015 : 10931125. The results from this paper are reported in Duflo and Bertrand, "Field Experiments on Discrimination."

223 Bertrand and Duflo, "Field Experiments on Discrimination," pp. 40-44.

224 Beasley, Opting Out; Beasley and Fischer, "Why They Leave."

225 Fernandez and Greenberg, "Race, Network Hiring, and Statistical Discrimination"; Rubineau and Fernandez, "Missing Links." Peterson et al., "Offering a Job," also found evidence that employers prefer to hire from referrals

${ }^{226}$ Fernandez and Greenberg, "Race, Network Hiring, and Statistical Discrimination," p. 81.

227 Beasley, "There Is a Supply of Diverse Workers in Tech"; Tomaskovic-Devey, "Written Testimony."
} 
and particularly the governance structures, that dominate in the U.S. economy, there will be little progress for Blacks in gaining access to the types of high-quality, well-remunerated jobs that leading U.S. technology firms have to offer.

The demise of OEBM was very damaging to the career prospects of Blacks in STEM occupations. Rationalization of blue-collar employment from the 1980s stifled the upward socioeconomic mobility that high-school-educated Blacks had experienced in the 1960s and 1970s. Without a concerted set of government policies to upgrade the education of African Americans combined with business policies to maintain sustained access to employment experience, upward mobility turned to downward mobility for a significant proportion of the Black population.

Marketization of employment in the 1990s and beyond put an end to the CWOC norm, for not only blue-collar workers but also college-educated white-collar employees. Our research suggests that marketization had a devastating impact on the quest for equal employment opportunity. As we have stressed, the EEOC institutions were designed with the notion of upward mobility in a corporate economy in which the dominant business enterprises adhered to the norm of a career with one company. In what we have called "the equal employment opportunity omission," 228 when the marketization of employment relations destroyed the CWOC norm from the 1990s, the EEOC institutions became economically ineffective (an outcome that Clarence Thomas had already set in motion politically when President Reagan appointed him to head EEOC in 1982).

And with the globalization of employment relations, the notion that new employment institutions to ensure the upward socioeconomic mobility of African Americans, and high-school-educated Americans more generally, needed to be put in place received little if any attention from government and business because the needs of the U.S. economy for a high-tech labor force were so amply filled by the availability to the U.S. labor force of highly educated personnel emanating from Asia.

The question, which we will take up in the concluding paper of the Fifty Years After project, is what accounts for this neglect on the part of major federal government agencies and leading U.S. business enterprises of the socioeconomic need to upgrade the productive capabilities and employment opportunities available to America's blue-collar households. Thus far in our five working papers, we have only touched upon a key characteristic of the $21^{\text {st }}$ century U.S. economy that is, in our view the cause of the extreme economic inequality that afflicts the nation, with Blacks more than any other demographic group bearing the brunt of it.

We are referring to the financialization of the U.S. business corporation, manifested more clearly and egregiously by the practice of U.S. business corporations repurchasing their own shares on the stock market for the purpose of giving manipulative boosts to their stock prices. The leading U.S. tech companies became dominant by retaining corporate profits and investing in the productive capabilities of their well-educated labor forces. Indeed, among the leading tech employers listed in Table V.22 and Table V.23, Amazon and Salesforce still do, paying no

\footnotetext{
${ }^{228}$ William Lazonick, Philip Moss, and Joshua Weitz, “The Equal Employment Opportunity Omission,” Institute for New Economic Thinking Working Paper No. 53, December 5, 2016, at https://www.ineteconomics.org/research/researchpapers/the-equal-employment-opportunity-omission.
} 
dividends and doing no buybacks. But most of the companies have become highly financialized, led by Apple, which from October 2012 through December 2021 devoted \$484 billion, equal to 92 percent of net income, to stock buybacks and another $\$ 118$ billion, another 23 percent of net income to dividends. ${ }^{229}$ Meanwhile, all of these companies, and the individuals who get rich from their stock yields benefit from a federal tax code structured for tax avoidance.

As already documented and analyzed by Lazonick and colleagues at the Academic-Industry Research Network in collaboration with the Institute for New Economic Thinking, and as we will explain fully in the forthcoming conclusion to the Fifty Years After project, but for the dominance since the mid-1980s of a highly damaging ideology that, for the sake of economic efficiency, a company should be run to maximize shareholder value, tens of millions of American households that have experienced downward socioeconomic mobility, African American households among them, could instead be the beneficiaries of an economy and society that delivers stable and equitable growth to an ever-expanding proportion of the working population.

229 For the relevant research, see the website of the Academic-Industry Research Network (www.theAIRnet.org) and William Lazonick webpages at the Institute for New Economic Thinking (https://www.ineteconomics.org/research/experts/wlazonick) and Harvard Business Review (https://hbr.org/search?term=william+lazonick). For data on distributions to shareholders by the leading corporate repurchasers, including Alphabet, Apple, Cisco, IBM, Intel, and Microsoft, see Lazonick and Hopkins, "Why the Chips Are Down." 


\section{References}

AFL-CIO, "Guest worker visas: The H-1B and the L-1," 2017 Fact Sheet, Department of Professional Employees, AFL-CIO, at https://dpeaflcio.org/programs-publications/issue-fact-sheets/guest-workervisas-the-h-1b-and-1-1/.

Angwin, Julia, and Laura Castaneda, "The Digital Divide: High-tech boom a bust for blacks, Latinos," San Francisco Chronicle, May 4, 1998, at https://www.sfgate.com/news/article/The-Digital-Divide-Hightech-boom-a-bust-for-3007911.php;a;sp, published in US Black Engineer and Information Technology, 22,2,1998: 28-20, 32, 34.

Anon., "American Immigration Lawyers Association Elects New President," PR Newswire, July 19, 1988.

Anon., "Jesse Jackson visits Silicon Valley, urges jobs for minorities," Associated Press Newswires, March 1, 1999.

Anon., "Google to release diversity data about workforce," Deccan Chronicle, May 14, 2014.

Ascend: Pan-Asian Leaders, "Who We Are," at https://www.ascendleadership.org/.

Beasley, Maya A., Opting Out: Losing the Potential of America's Young Black Elite, Chicago University Press, 2011.

Beasley, Maya, "There Is a Supply of Diverse Workers in Tech, So Why Is Silicon Valley So Lacking in Diversity?" Center for American Progress, 2017, at https://cdn.americanprogress.org/content/uploads/2017/03/28141805/TechDiversity-report3.pdf.

Beasley, Maya, and Mary Fischer, "Why They Leave: The Impact of Stereotype Threat on the Attrition of Women and Minorities from Science, Math and Engineering Majors," Social Psychology Education 15, 4. 2012: 427-448.

Benner, Chris, Work in the New Economy: Flexible Labor Markets in Silicon Valley, Wiley-Blackwell, 2002.

Bennett, Pamela R., "Book Review of Beasley, Opting Out," American Journal of Sociology, 118, 6, 2013: 1731-1733.

Bertrand, Marianna, and Esther Duflo, "Field Experiments on Discrimination," in Abhijit Banerjee and Esther Duflo, eds. Handbook of Field Experiments, J-Pal, 2016, at https://www.povertyactionlab.org/handbook-field-experiments.

Bertrand, Marianne, and Sendhil Mullainathan, "Are Emily and Greg More Employable Than Lakisha and Jamal? A Field Experiment on Labor Market Discrimination," American Economic Review, 94, 4, 2004: 991-1013.

Best, Michael H., The New Competitive Advantage: The Renewal of American Industry, Oxford University Press, 2001.

Boushey, Heather, Shawn Fremstad, Rachel Gragg, and Margy Waller, "Understanding Low-Wage Work in the United States," March 2007, at https://core.ac.uk/download/pdf/6967463.pdf.

Brown v. Board of Education of Topeka, 347 U.S. 483, 493 (1954).

Burbridge, Lynn C., "Changes in Equal Employment Enforcement: What Enforcement Statistics Tell Us," Review of Black Political Economy, 15, 1, 1986: 71-80.

Byrne, Ciara, "This basic fact about social networks disadvantages minorities," Fast Company,

September 5, 2018, at https://www.fastcompany.com/90220470/this-basic-fact-about-social-networksdisadvantages-minorities. 
California Department of Fair Housing and Employment, "California Pay Data Reporting: Frequently Asked Questions," ca.gov, February 3, 2022., at https://www.dfeh.ca.gov/paydatareporting/faqs/.

Carnevale, Anthony, Megan Fasules, Andrea Porter, Jennifer Landis-Santos, "African Americans:

College Majors and Earnings," Georgetown University Center on Education and the Workforce, 2016, Appendix: pp. 6-7, at https://1 gyhoq479ufd3yna29x7ubjn-wpengine.netdna-ssl.com/wpcontent/uploads/AfricanAmericanMajors_2016 web.pdf.

Celarier, Michelle, "How a misfit group of computer geeks and English majors transformed Wall Street," New York, January 18, 2018, at http://nymag.com/intelligencer/2018/01/d-e-shaw-the-first-great-quanthedge-fund.html.

Chase Susan E., "Book Review of Beasley, Opting Out," The Review of Higher Education, 36, 3, 2013: 408-409.

Chen, Xianglei, and Matthew Solder, “STEM Attrition: College Students' Paths Into and Out of STEM Fields," National Center for Educational Statistics, 2013, Table 2, at https://nces.ed.gov/pubs2014/2014001rev.pdf.

Collins, Sharon M., "Diversity in the Post Affirmative Action Labor Market: A Proxy for Racial Progress?" Critical Sociology, 37, 5, 2011: 521-540.

Demmitt, Jacob, "85 percent of Amazon's black U.S. workers hold unskilled jobs," Puget Sound Business Journal Online, June 11, 2015.

Demmitt, Jacob, "Microsoft quietly makes good on promise to reveal diversity stats, posts Equal Employment data," Dallas Business Journal Online, January 2, 2015.

DePalma, Anthony, “Graduate schools fill with foreigners,” New York Times, November 29, 1990.

Dickey, Megan Rose, "The Future of Diversity and Inclusion in Tech," TechCrunch.com, June 17, 2019, at https://techcrunch.com/2019/06/17/the-future-of-diversity-and-inclusion-in-tech/.

Dobbin, Frank, and Alexandra Kalev, "The Architecture of Inclusion: Evidence from Corporate Diversity Programs," Harvard Journal of Law \& Gender, 30, 2, 2007: 279-301.

Dobbin, Frank, and Alexandra Kalev, "Why Diversity Programs Fail," Harvard Business Review, 94, 7 , 2016: 52-60.

Dobbin, Frank, Daniel Schrage, and Alexandra Kalev, "Rage Against the Iron Cage: The Varied Effects of Bureaucratic Personnel Reforms on Diversity," American Sociological Review, 80, 5, 2015: 1014 1044.

Durkin, Erin "Amazon HQ2: tech giant splits new home across New York City and Virginia," Guardian, November 13, 2020, at https://www.theguardian.com/technology/2018/nov/13/amazon-hq2-secondheadquarters-new-york-city-virginia.

eBay, "eBay Annual Shareholder Meeting - Final,” CQ FD Disclosure, May 13, 2014.

EdBuild, "Nonwhite school districts get $\$ 23$ billion less than white districts despite serving the same number of students," 23 Billion, at https://edbuild.org/content/23-billion.

Eguchi, Ryosuke, "Samsung overtook Intel as top chip seller in 2021," Nikkei Asia, January 20, 2022.

Elstrom, Peter, "Gates to Senate: More visas," Business Week, March 8, 2007.

Facebook, "Facebook Annual Shareholder Meeting - Final," CQ FD Disclosure, May 22, 2014.

Falcon, Luis M., "Social Networks and Employment for Latinos, Blacks, and Whites," New England Journal of Public Policy, 11, 1, 1995: 17-28. 
Fallick, Bruce, Charles A. Fleischman and James B. Rebitzer, "Job-Hopping in Silicon Valley: Some Evidence Concerning the Microfoundations of a High-Technology Cluster," Review of Economics and Statistics, 88, 3, 2006: 472-481.

Federal Reserve Board of St. Louis, "FRED Economic Data: Civilian Labor Force (CLF160V)," at https://fred.stlouisfed.org/series/CLF16OV.

Fernandez, Roberto M., and Isabel Fernandez-Mateo, "Networks, Race, and Hiring," American Sociological Review, 71, 1, 2006: 42-71.

Fernandez, Roberto M., and Roman Galperin, "Contemporary Perspectives on Organizational Social Networks," in Ajay Mehra, Daniel J. Brass, Daniel S. Halgin, Giuseppe Labianca, and Stephen P.

Borgatti, eds., The Causal Status of Social Capital in Labor Markets, Emerald Group Publishing, 2014: 445-462.

Fernandez, Roberto M., and Jason Greenberg, "Race, Network Hiring, and Statistical Discrimination," in Steve McDonald, ed., Networks, Work and Inequality, Emerald Group Publishing, 2013: 81-102.

Florida, Richard, "The extreme geographic inequality of high-tech venture capital," CityLab, March 27, 2018, at https://www.citylab.com/life/2018/03/the-extreme-geographic-inequality-of-high-tech-venturecapital $/ 552026 /$.

Fowler, Elizabeth M., "Financing engineers' education,” New York Times, February 3, 1982.

Fowler, Elizabeth M., “Focus on factory engineers,” New York Times, June 29, 1983.

Fowler, Elizabeth M., "Engineers and quest for M.B.A.," New York Times, January 9, 1985.

Gee, Buck, and Denise Peck, "The Illusion of Asian Success: Scant Progress for Minorities in Cracking the Glass Ceiling from 2007-2015," Ascend: Pan-Asian Leaders, at https://c.ymcdn.com/sites/www.ascendleadership.org/resource/resmgr/research/TheIllusionofAsianSucces s.pdf.

Gibson, Campbell, and Kay Jung, "Historical Census Statistics on the Foreign-Born Population of the United States: 1850 to 2000," Population Division, U.S. Census

Bureau, Working Paper No. 81, February 2006, at

https:/www.census.gov/population/www/documentation/twps0081/twps0081.html;

Glassdoor, “Apple salaries,” at https://www.glassdoor.com/Salary/Apple-Salaries-E1138.htm.

Granovetter, Mark, “The Strength of Weak Ties,” American Journal of Sociology, 78, 6, 1973: 13601380.

Granovetter, Mark, Getting a Job: A Study of Contacts and Careers, Harvard University Press,1974.

Grasgreen, Allie, “Opting Out,” InSide Higher Ed, December 2, 2011.

Green, Dennis, “Amazon cancels New York HQ2," Business Insider, February 14, 2019, at

https://www.businessinsider.com/amazon-cancels-new-york-hq2-2019-

2\#: : :text=Amazon $\% 20$ has $\% 20$ canceled $\% 20$ its $\% 20$ HQ2,Queens $\% 2 \mathrm{C} \% 22 \% 20$ the $\% 20$ company $\% 20$ wrote

Guynn, Jessica, "Diversity takes center stage at Microsoft annual meeting," USA Today, December 3, 2014.

Guynn, Jessica, “Apple, Amazon refuse to release federal diversity data," USA Today, December 8, 2014.

Hammond, Linda Darling, "Unequal Opportunity: Race and Education," Brookings Institution, March 1, 1998, at https://www.brookings.edu/articles/unequal-opportunity-race-and-education/.

Hardy, Quentin, “Jesse Jackson confronts Silicon Valley,” New York Times, March 19, 2014, at https://bits.blogs.nytimes.com/2014/03/19/jesse-jackson-confronts-silicon-valley/. 
Hartocollis, Anemona, "The Harvard Bias Suit by Asian-Americans: 5 Key Issues" New York Times, December 20, 2018, at https://www.nytimes.com/2018/12/20/us/harvard-asian-american-studentsdiscrimination.html.

Haynes, V. Dion, "High-tech heavyweights offer advice to minority business people," Chicago Tribune, April 26, 2002.

Heckman, James J., "Detecting Discrimination”, Journal of Economic Perspectives, 12, 2, 1998: 101-116 Hewlett-Packard Company, Annual Reports, 1957-1989.

Hira, Ron, "Bridge to Immigration or Cheap Temporary Labor? The H-1B and L-1 Visa Programs Are a Source of Both," EPI Briefing Paper \#257, Economic Policy Institute, February 17, 2010, at https://www.epi.org/publication/bp257/.

Hira, Ron, "Congressional Testimony: The Impact of High-Skilled Immigration on U.S. Workers," Economic Policy Institute, March 1, 2016, at https://www.epi.org/publication/congressional-testimonythe-impact-of-high-skilled-immigration-on-u-s-workers-4/.

Hira, Ron, "Top ten users of H-1B guest worker program are all offshore outsourcing firms," Economic Policy Institute, February 14, 2013.

Hirschman, Charles, and Morrison G. Wong, "The Extraordinary Educational Attainment of Asian Americans: A Search for Historical Evidence and Explanations," Social Forces, 65, 1, 1986: 1-27.

Hoeffel, Elizabeth M., Sonya Rastogi, Myoung Ouk Kim, and Hasan Shahid, "The Asian Population: 2010,” 2010 Census Briefs, U.S. Census Bureau, March 2012, at https://www.census.gov/prod/cen2010/briefs/c2010br-11.pdf.

Hopkins, Matt, and William Lazonick, "The Mismeasure of Mammon, Uses and Abuses of Executive Pay Data," Institute for New Economic Thinking Working Paper No. 49, August 29, 2016, at https://www.ineteconomics.org/research/research-papers/the-mismeasure-of-mammon-uses-and-abusesof-executive-pay-data.

HP press release, "Celebrates three years of community/high-tech collaboration; \$5 million HP grant achieving goal of sustainable economic and educational development," Associated Press Newswires, April 29, 2003.

HP press release, "East Palo Alto celebrates community milestones achieved through $\$ 5$ million HP Digital Village program grant; Mayor Duane Bay proclaims 'HP Digital Village Day'," Business Wire, April 23, 2002.

HP press release, "HP pioneers new approach to social venture philanthropy; Two communities join East Palo Alto in becoming digitally connected with $\$ 5$ million each in HP resources," M2 Presswire, February 14, 2001.

HP press release, "HP's pioneering approach to social venture philanthropy goes global; Communities in Ghana, France and South Africa Selected as HP Digital Villages," M2 Presswire, October 11, 2001.

Hsu, Hua, "The rise and fall of Affirmative Action” The New Yorker, October 8, 2018.

Hsu, Madeline Y., The Good Immigrants: How the Yellow Peril Became the Model Minority, Princeton University Press.

IBM, Annual Reports, 1972, 1974, 1976, 1978, 1979,1986, 1989.

Intel, Intel 2017, 2018, and 2019 EEO-1 Pay Disclosure," Intel Corporation, n.d., at https://www.intel.com/content/www/us/en/diversity/2017-2019-eeo-1-pay-disclosure-report.html.

Jackson, C. Kirabo, "Does School Spending Matter? The New Literature on An Old Question,” National Bureau of Economic Research, Working Paper 25368, 2018, at http://www.nber.org/papers/w25368. 
Jackson, C. Kirabo, Rucker C. Johnson, and Claudia Persico, "The Effects of School Spending on Educational and Economic Outcomes: Evidence from School Finance Reforms," Quarterly Journal of Economics, 131, 1, 2016: 157-218.

Johnson, Jean M., and Mark C. Regets, "International Mobility of Scientists and Engineers to the United States-Brain Drain or Brain Circulation?" National Science Foundation, Division of Science Resources Studies Issue Brief, NSF 98-316, 1998, at https://www.nsf.gov/statistics/issuebrf/sib98316.htm.

Kalev, Alexandra, Frank Dobbin, and Erin Kelly, "Best Practices or Best Guesses? Assessing the Efficacy of Corporate Affirmative Action and Diversity Policies," American Sociological Review, 71, 4, 2006 : 589-617.

Kelly, Erin, and Frank Dobbin, "How Affirmative Action Became Diversity Management," American Behavioral Scientist; 41, 7, 1998: 960-984.

Kurtulus, Fidan Ana, “The Impact of Affirmative Action on the Employment of Minorities and Women: A Longitudinal Analysis Using Three Decades of EEO-1 Filings," Journal of Policy Analysis and Management, 35, 1, 2016: 34-66.

Lafortune, Julien, Jesse Rothstein, and Diane Whitmore Schanzenbach, "School Finance Reform and the Distribution of Student Achievement," American Economic Journal: Applied Economics, 10, 2, 2018: 126.

Lazonick, William, Sustainable Prosperity in the New Economy? Business Organization and High-tech Employment in the United States, W. E. Upjohn Institute for Employment Research, 2009, chs. 2-3, at https://doi.org/10.17848/9781441639851.

Lazonick, William, "The New Economy Business Model and the Crisis of U.S. Capitalism," Capitalism and Society, 4, 2, 2009: Article 4.

Lazonick, William, "Labor in the Twenty-First Century: The Top $0.1 \%$ and the Disappearing Middle Class," in Christian E. Weller, ed., Inequality, Uncertainty, and Opportunity: The Varied and Growing Role of Finance in Labor Relations, Cornell University Press, 2015: 143-192.

Lazonick, William, "How the U.S. New Economy Business Model Has Devalued Science and Engineering PhDs," Institute for New Economic Thinking Commentary, May 9, 2017, at https://www.ineteconomics.org/perspectives/blog/marketization-and-financialization.

Lazonick, William, “The secret of Amazon's success,” New York Times, November 19, 2018, at https://www.nytimes.com/2018/11/19/opinion/amazon-bezos-hq2.html.

Lazonick, William, and Matt Hopkins, "Why the CHIPS Are Down: Stock Buybacks and Subsidies in the U.S. Semiconductor Industry," Institute for New Economic Thinking Working Paper No. 165, November 1, 2021, at https://www.ineteconomics.org/research/research-papers/why-the-chips-are-down-stockbuybacks-and-subsidies-in-the-u-s-semiconductor-industry.

Lazonick, William, and Jang-Sup Shin, Predatory Value Extraction: How the Looting of the Business Corporation Became the US Norm and How Sustainable Prosperity Can Be Restored, Oxford University Press, 2020.

Lazonick, William, Philip Moss, and Joshua Weitz, "The Equal Employment Opportunity Omission,” Institute for New Economic Thinking Working Paper No. 53, December 5, 2016, at https://www.ineteconomics.org/research/research-papers/the-equal-employment-opportunity-omission.

Lazonick, William, Philip Moss, and Joshua Weitz, "The Unmaking of a Black Blue-Collar Middle Class," Institute for New Economic Thinking Working Paper No. 159, May 20, 2021, at https://www.ineteconomics.org/research/research-papers/the-unmaking-of-the-black-blue-collar-middleclass. 
Lazonick, William, Philip Moss, and Joshua Weitz, "How the Disappearance of Unionized Jobs Obliterated an Emergent Black Middle Class," Institute for New Economic Thinking Working Paper No. 1255, June 15, 2021, at https://www.ineteconomics.org/research/research-papers/how-the-disappearanceof-unionized-jobs-obliterated-an-emergent-black-middle-class.

Lee, Jennifer, and Min Zhou, The Asian American Achievement Paradox, Russell Sage Foundation, 2015. Lee, Susan, "Train 'em here: Foreign students crowd our schools for advanced scientific and engineering education," Forbes, 147, 11, 1991: 110-116.

Leonard, Jonathan S., "The Impact of Affirmative Action on Employment," Journal of Labor Economics, 2, 4 1984: 439-463.

Leonard, Jonathan S., "The Impact of Affirmative Action Regulation and Equal Employment Law on Black Employment," Journal of Economic Perspectives, 4, 4, 1990: 47-63.

Levin, Sam, "Women say they quit Google because of racial discrimination: 'I was invisible'," The Guardian, August 18, 2017, at https://www.theguardian.com/technology/2017/aug/18/women-googlememo-racism-sexism-discrimination-quit.

Levin, Sam, "US government v Silicon Valley: Oracle said to owe $\$ 400 \mathrm{~m}$ to women and minorities," The Guardian, January 23, 2019.

Liptak, Adam, and Anemona Hartocollis, "Supreme Court will hear challenge to affirmative action at Harvard and U.N.C,", New York Times, January 24, 2022, at https://www.nytimes.com/2022/01/24/us/politics/supreme-court-affirmative-action-harvard-unc.html.

Lowell, B. Lindsay, "H-1B Temporary Workers: Estimating the Population," Center for Comparative Immigration Studies Working Paper No. 12. University of California, San Diego, May 2000, p. 3, at https://escholarship.org/uc/item/4ms039dc.

Lubman, Sarah, "Jesse Jackson says Silicon Valley boardrooms must reflect greater diversity," San Jose Mercury News, April 13, 1999.

Lubman, Sarah, "Jesse Jackson, high-tech sector sees many changes since gaining board access," San Jose Mercury News, April 23, 2002.

Luhby, Tami, "Amazon eliminates bonuses and stock awards for hourly workers," CNN Business, October 4, 2018, at https://www.cnn.com/2018/10/04/business/amazon-minimum-wage-

bonus/index.html.

Mailman, Stanley, and Stephen Yale-Loehr, "Foreign nurses: Dealing with the shortage." New York Law Journal, December 22, 2003.

McDonald, Steve, "Networks of Opportunity: Gender, Race, and Job Leads," Social Problems, 56, 3, 2009: 385-402.

McPherson, Miller, Lynn Smith-Lovin, and James M Cook, "Birds of a Feather: Homophily in Social Networks", Annual Review of Sociology, 27, 2001: 415-444.

Mendoza, Martha, "Google's diversity data reveals largely white, male workforce but striving for change," Associated Press, May 29, 2014.

Mendoza, Martha, "High-tech CEOs pledge to diversify work forces," Associated Press, May 3, 2000.

Miller, Conrad, "The Persistent Effect of Temporary Affirmative Action," American Economic Journal: Applied Economics, 9, 3 2017: 152-190,

Moss, Philip, and Chris Tilley, Stories Employers Tell: Race and Hiring in America, Russell Sage, 2001. 
Moss, Philip, William Lazonick, and Joshua Weitz, "Employment and Earnings of African Americans Fifty Years After: Progress?” Institute for New Economic Thinking Working Paper No. 129. July 13, 2020, at https://www.ineteconomics.org/research/research-papers/employment-and-earnings-of-africanamericans-fifty-years-after-progress.

National Center for Education Statistics, "Program for International Student Assessment (PISA)," at https://nces.ed.gov/surveys/pisa/.

National Center for Education Statistics, "Program for International Student Assessment (PISA)," PISA Data Explorer, at https://nces.ed.gov/surveys/international/ide/.

National Science Foundation, Division of Science Resources Statistics S\&E degrees, by Race/Ethnicity of Recipients: 1995-2004, No NSF 07-308 2007, at https://www.nsf.gov/statistics/degreerecipients/.

National Science Foundation, National Center for Science and Engineering Statistics, "Survey of Graduate Students and Post-Doctorates in Science and Engineering, Fall 2016," at https://ncsesdata.nsf.gov/gradpostdoc/2016/.

National Science Foundation, "Scientists and Engineers Statistical Data System," at https://sestat.nsf.gov/sestat/sestat.html.

Neate, Rupert, “Apple's senior executives are 70\% white men, diversity filing reveals," The Guardian, August 4, 2015.

Nunley, John M., Adam Pugh, Nicholas Romero, and R. Alan Seals, "Racial Discrimination in the Labor Market for Recent College Graduates: Evidence from a Field Experiment," The B.E. Journal of Economic Analysis \& Policy, 15, 3, 2015: 1093-1125.

Packard, David, The HP Way: How Bill Hewlett and I Built Our Company, HarperBusiness, 1995.

Pager, Devah, "The Use of Field Experiments for Studies of Employment Discrimination: Contributions, Critiques, and Directions for the Future," Annals of the American Academy of Political and Social Sciences, 609, 2007: 104-133.

Pager, Devah, and Bruce Western, "Identifying Discrimination at Work: The Use of Field Experiments," Journal of Social Issues, 68, 2, 2012: 221-227.

Perlstein, Joanna, “The Schools Where Apple, Google, and Facebook Get Their Recruits," Wired, May 22, 2014, at https://www.wired.com/2014/05/alumni-network-2/.

Petersen, Trond, Ishak Saporta and Marc-David L. Seidel, "Offering a Job: Meritocracy and Social Networks," American Journal of Sociology, 106, 3, 2000: 763-816.

Pew Research Center, "The Rise of Asian Americans," April 4, 2013, at http://www.pewsocialtrends.org/2012/06/19/the-rise-of-asian-americans/, pp. 2 and 10,

Potter, Halley, "What Can We Learn from States That Ban Affirmative Action?" The Century Foundation, 2014, at https://tcf.org/content/commentary/what-can-we-learn-from-states-that-banaffirmative-action/.

Pramanik, Ayan, and Priyanka Sangani, "H-1B extension rejections rob Indian IT firms of visa power," Economic Times, March 8, 2018, at https://economictimes.indiatimes.com/nri/visa-and-immigration/h-1bextension-rejections-rob-indian-it-firms-of-visa-power/articleshow/68312136.cms.

PRC Silicon Valley, at http://www.rainbowpushsv.org/about/.

Quillian, Lincoln, Devah Pager, Ole Hexel, and Arnfinn H. Midtbøen, "Meta-analysis of Field Experiments Shows No Change in Racial Discrimination in Hiring over Time," Proceedings of the National Academy of Sciences, 2017: 1-6 
Radnofsky, Louise, “Approval rate declined for H-1B visas,” Wall Street Journal, February 23, 2019, at https://www.wsj.com/articles/approval-rate-declines-for-h-1b-visas-11550926800.

Reardon, Sean, “The Widening Income Achievement Gap,” Educational Leadership, 70, 8, 2013: 10-16.

Reardon, Sean, "School Segregation and Racial Academic Achievement Gaps," Russell Sage Foundation Journal of the Social Sciences, 2, 5, 2016: 34-57.

Reardon, Sean. Demetra Kalogrides and Kenneth Shores, "The Geography of Racial/Ethnic Test Score Gaps, Stanford University Center for Education Policy," American Journal of Sociology, 124, 4, 2019 : 1164-1221.

Reardon, Sean, Joseph Robinson, and Ericka S. Weathers, "Patterns and Trends in Racial/Ethnic and Socioeconomic Academic Achievement Gaps," in Helen A. Ladd and Margaret E. Goertz, eds., Handbook of Research in Education Finance and Policy, Routledge, 2014: 491-509.

Reskin, Barbara F., and Denise D. Bielby, "A Sociological Perspective on Gender and Career Outcomes," Journal of Economic Perspectives, 19, 1, 2005: 71-86.

Reveal from the Center for Investigative Reporting, "Silicon Valley diversity data: Who released theirs, who didn't?" October 19, 2017, at https://s3-us-west-1.amazonaws.com/apps-staging-revealnewsorg/silicon-valley-diversity-list/index.html/.

Ribeiro, John, "Google concedes in diversity data that employees mainly male and white," All Africa, May 29, 2014.

Rigby, Bill, "Former CEO Ballmer, activist Jesse Jackson enliven Microsoft meeting," Reuters News, December 3, 2014

Rogoway, Mike, "Intel's CEO comes to Oregon, stumping for billions to aid his industry and his company," The Oregonian, December 5, 2021, at https://www.oregonlive.com/siliconforest/2021/12/intels-ceo-comes-to-oregon-stumping-for-billions-to-aid-his-industry-and-hiscompany.html.

Rothwell, Jonathan, "Housing Costs, Zoning, and Access to High Scoring Schools," Metropolitan Policy Program Report, Brookings Institution, April 2012, p. 9, at https:/www.brookings.edu/research/housingcosts-zoning-and-access-to-high-scoring-schools/ .

Rubineau, Brian, and Roberto M. Fernandez, "Missing Links: Referrer Behavior and Job Segregation," Management Science, 59, 11, 2013: 2470-2489.

Sailors, John, "Yahoo reveals diversity data: It's mostly white and male," San Francisco Business Times Online," June 18, 2014.

Saxenian, AnnaLee, The New Argonauts: Regional Advantage in a Global Economy, Harvard University Press, 2007.

Scott, Allison, Freada Kapor Klein, and Uriridiakoghene Onovakpuri, “Tech Leavers Study,” Kapor Center for Social Impact, 2017, at https:/www.kaporcenter.org/wp-

content/uploads/2017/08/TechLeavers2017.pdf.

Sharpe, Rochelle, "Losing ground: In latest recession, only blacks suffered net employment loss," Wall Street Journal, September 14, 1993, A1.

Sharpe, Rochelle, "Unequal opportunity: Losing ground on the employment front," Wall Street Journal, September 14, 1993: A12-A13.

Smith, Noah, "Venture capital needs some geographic diversity," Bloomberg Opinion, August 28, 2018, at https://www.bloomberg.com/opinion/articles/2018-08-28/venture-capital-needs-some-geographicdiversity. 
Spatig-Amerikaner, Ary, "Unequal Education: Federal Loophole Enables Lower Spending on Students of Color," Center for American Progress, August 12, 2012, at

https://www.americanprogress.org/issues/education-k-12/reports/2012/08/22/29002/unequal-education/;,

Swartz, Jon, “Rev. Jackson to Apple: March for diversity not over,” USA Today, March 10, 2015.

Szabo, Joan C., “Opening Doors for Immigrants,” Nation's Business, August 1, 1989.

Teitelbaum, Michael S., “Too Many Engineers, Too Few Jobs.” New York Times, March 19, 1996.

The Editors, "Do we need foreign technology workers?" New York Times, April 8, 2009, at

https://roomfordebate.blogs.nytimes.com/2009/04/08/do-we-need-foreign-technology-workers/.

The World Bank, The East Asian Miracle: Economic Growth and Public Policy, Oxford University Press, 1993.

Tomaskovic-Devey, Donald, "Written Testimony of Donald Tomaskovic-Devey," Equal Employment Opportunity Commission, July 2015, at https://www.eeoc.gov/eeoc/meetings/7-1-15/devey.cfm.

Tomaskovic-Devey, Donald, and Kevin Stainback, "Discrimination and Desegregation: Equal Opportunity Progress in U.S. Private Sector Workplaces since the Civil Rights Act", Annals of the American Academy of Political and Social Science, 609, 2007: 56-58.

U.S. Commission on Civil Rights, "Public Education Funding Inequity in an Era of Increasing Concentration of Poverty and Resegregation," Briefing Report, January 2018, at https://www.usccr.gov/pubs/2018/2018-01-10-Education-Inequity.pdf

U.S. Department of Commerce, United States Census Bureau, "Asians and Pacific Islanders in the United States," 1990 Census of the Population, Table 3, at https:/www.census.gov/prod/cen1990/cp3/cp-3-5.pdf.

U.S. Department of Commerce, U.S. Census Bureau, "Asian and Pacific Islander, for the United States, Regions, Divisions, and States, 1990," Appendix Table C-1, September 13, 2002.

U. S. Department of Education, "A Nation at Risk: The Imperative of Educational Reform," A Report to the Nation and the Secretary of Education, United States Department of Education by The National Commission on Excellence in Education, April 1983, at https:/www.edreform.com/wp-

content/uploads/2013/02/A_Nation_At_Risk_1983.pdf.

U.S. Department of Homeland Security, "Persons Obtaining Lawful Permanent Resident Status by Broad Class of Admission and Region and Country of Birth," Yearbook of Immigration Statistics, editions 1996 to 2019, at https://www.dhs.gov/immigration-statistics/yearbook.

U.S. Department of Justice, 1997 Statistical Yearbook of the Immigration and Naturalization Service, U.S. Government Printing Office, 1999.

U.S. Department of Labor, "U.S. Department of Labor reaches $\$ 5$ million settlement with Intel Corp. to resolve pay discrimination allegations," Office of Federal Contract Compliance Programs News Release, October 15, 2019, at https://www.dol.gov/newsroom/releases/ofccp/ofccp20191015.

U.S. Department of State, Nonimmigrant Visa Statistics, "FY1997-2020 NIV Detail Table (Excel spreadsheet)," at https://travel.state.gov/content/travel/en/legal/visa-law0/visa-statistics/nonimmigrantvisa-statistics.html.

U.S. Equal Employment Opportunity Commission, "Diversity in High Tech," EEOC, May 2016, at https://www.eeoc.gov/special-report/diversity-high-tech.

U.S. Equal Opportunity Employment Commission, "EEOC announces analysis of EEO-1 Component 2 Pay Data Collection," EEOC press release, July 16, 2020, at https://www.eeoc.gov/newsroom/eeocannounces-analysis-eeo-1-component-2-pay-data-collection. 
U.S. General Accounting Office, "Equal Employment Opportunity: EEOC and State Agencies Did Not Fully Investigate Discrimination Charges," General Accounting Office, Human Resource Division, GAO/HRD-89-11, October 1988: 3-4, at https://www.gao.gov/assets/hrd-89-11.pdf.

U.S. House of Representatives, "Joint Hearings before the Subcommittee of Immigration, Refugees, and International Law of the Committee of the Judiciary and the Immigration Task Force of the Committee on Education and Labor," 101st Congress, Second Session, on S. 358, H.R. 672, H.R. 2448, H.R. 2646, and H.R 4165, Immigration Act of 1989, February 21, March 1, 7, 13, and 14, 1990.

Vaghul, Kavya, "A small fraction of corporations share diversity data, but disclosure is rapidly on the rise," Just Capital, January 19, 2021, at https://justcapital.com/news/a-small-fraction-of-corporationsshare-diversity-data-but-disclosure-is-rapidly-on-the-rise/.

Vaughan, Jessica, “Shortcuts to Immigration: The 'Temporary' Visa Program is Broken,” Backgrounder. Washington, DC: Center for Immigration Studies, January 1, 2003, at https://cis.org/Report/ShortcutsImmigration-Temporary-Visa-Program-Broken.

von Romburgh, Marlize, "How much the CEOs of Facebook, Alphabet, Intel, Twitter, eBay, Tesla, ad other big Bay Area tech employers make compared to their workers," Silicon Valley Business journal, June 5, 2018, at https://www.bizjournals.com/sanjose/news/2018/06/05/tech-ceo-pay-ratio-fb-goog-intctwtr-tsla-nflx-crm.html.

Watson Jr, Thomas J., and Peter Petrie, Father, Son, \& Co.: My Life at IBM and Beyond, Bantam Books, 1990.

Weathers, Ericka S., and Victoria E. Sosina, "Separate Remains Unequal: Contemporary Segregation and Racial Disparities in School District Revenue," Stanford University Center for Education Policy, Working Paper No. 19-02, March 2019.

Weinstein, Eric R., "How and Why Government, Universities, and Industry Create Domestic Shortages of Scientists and High-Tech Workers," Institute for New Economic Thinking Commentary, March 28, 2017 (originally published by the National Bureau of Economic Research in 1998), at https://www.ineteconomics.org/perspectives/blog/how-why-government-universities-industry-createdomestic-labor-shortages-of-scientists-high-tech-workers.

Weise, Karen, "Amazon to raise minimum wage to \$15 for all U.S, workers," New York Times, October 2, 2018, at https://www.nytimes.com/2018/10/02/business/amazon-minimum-wage.html.

Weitz, Joshua, William Lazonick, and Philip Moss, "Employment Mobility and the Belated Emergence of the Black Middle Class," Institute for New Economic Thinking Working Paper No. 143, January 2, 2021, pp. 26-33, at https://www.ineteconomics.org/research/research-papers/employment-mobility-and-thebelated-emergence-of-the-black-middle-class.

Welch, William M., "Thomas presided over shift in policy at EEOC, records show," AP News, July 25, 1991, at https://apnews.com/article/b419883e871b5117649d1f3fdacf6f95.

Wilson, William Julius, When Work Disappears, Knopf, 1999.

Wong, Julia Carrie, "Segregated Valley: the ugly truth about Google and diversity in tech", The Guardian, August 7, 2017, at https://www.theguardian.com/technology/2017/aug/07/silicon-valleygoogle-diversity-black-women-workers.

Yale-Loehr, Stephen, "Examining the Importance of the H-1B Visa to the American Economy," Testimony before the U.S. Senate Committee on the Judiciary, September 16, 2003, at https://www.judiciary.senate.gov/imo/media/doc/yale-loehr testimony 09 16 03.pdf.

Yale-Loehr, Stephen, "The L-1 Visa and American Interests in the 21st Century Global Economy," Testimony before the U.S. Senate Committee on the Judiciary Subcommittee on Immigration and Border 
Security, July 29. 2003, at https:/www.jackson-hertogs.com/testimony-by-stephen-yale-loehr-on-1-1visas/.

Yang, Jia Lynn, One Mighty and Irresistible Tide: The Epic Struggle Over American Immigration, 19241965, W.W. Norton, 2020.

Yoder, Stephen Kreider, "Costly exports: Reverse 'brain drain' helps Asia but robs U.S. of scarce talent," Wall Street Journal, April 18, 1989.

Zimmer, Ben, “Quants,” New York Times Magazine, May 13, 2010, at https://www.nytimes.com/2010/05/16/magazine/16FOB-OnLanguage-t.html. 